\title{
Testing of Noodle Creek Site 41JS102 Jones County, Texas
}

\author{
J. Michael Quigg \\ Grant D. Smith \\ Audrey L. Scott \\ Jeffrey D. Owens
}

Follow this and additional works at: https://scholarworks.sfasu.edu/ita

Part of the American Material Culture Commons, Archaeological Anthropology Commons, Environmental Studies Commons, Other American Studies Commons, Other Arts and Humanities Commons, Other History of Art, Architecture, and Archaeology Commons, and the United States History Commons

Tell us how this article helped you.

This Article is brought to you for free and open access by the Center for Regional Heritage Research at SFA ScholarWorks. It has been accepted for inclusion in Index of Texas Archaeology: Open Access Gray Literature from the Lone Star State by an authorized editor of SFA ScholarWorks. For more information, please contact cdsscholarworks@sfasu.edu. 


\section{Testing of Noodle Creek Site 41JS102 Jones County, Texas}

\section{Licensing Statement}

This is a work produced for the Texas Department of Transportation (TxDOT) by the report producer. TxDOT and the report producer jointly own all rights, title, and interest in and to all intellectual property developed under TXDOT's contract with the report producer. The report may be cited and brief passages from this publication may be reproduced without permission provided that credit is given to both TxDOT and the report producer. Permission to reprint an entire chapter, section, figures or tables must be obtained in advance from either the Supervisor of the Archeological Studies Branch, Environmental Affairs Division, Texas Department of Transportation, 125 East 11th Street, Austin, Texas, 78701 or from the report producer. 


\title{
TRC
}

\section{Testing of Noodle Creek Site 41JS102 Jones County, Texas}

\author{
Prepared for: \\ ${ }_{7 \text { Texas Department of Transportation }}$ \\ Environmental Affairs Division \\ Archeological Studies Program \\ Report No. 48 \\ Prepared by: \\ J. Michael Quigg, Grant D. Smith, \\ Audrey L. Scott, and Jeffrey D. Owens

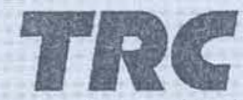 \\ Customerfocused Solutions \\ TRC Technical Report 35398 \\ J. Michael Quigg, Principal Investigator \\ Texas Antiquities Permit No. 2746
}

December 2002 


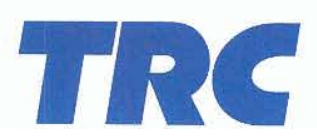

Customer-Focused Solutions

\title{
Testing of Noodle Creek Site 41JS102 Jones County, Texas
}

\author{
Prepared for:

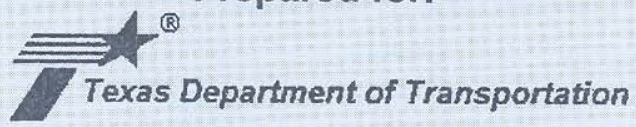 \\ Environmental Affairs Division \\ Archeological Studies Program \\ Report No. 48 \\ Austin, Texas
}

Prepared by:

J. Michael Quigg, Grant D. Smith, Audrey L. Scott, and Jeffrey D. Owens

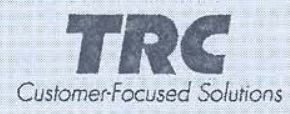

TRC Technical Report 35398 TRC Environmental Corporation 505 East Huntland Dr., Suite 250

Austin, Texas 78752 
Copyright $@ 2002$

Texas Department of Transportation (TxDOT) and TRC Environmental Corporation (TRC)

TxDOT and TRC jointly own all rights, title, and interest in and to all data and other information developed for this project under Contract 572XXSA004. Brief passages from this publication may be reproduced without permission provided that credit is given to TXDOT and TRC. Permission to reprint an entire chapter, section, figures or tables must be obtained in advance from the Supervisor of the Archeological Studies Program, Environmental Affairs Division, Texas Department of Transportation, 125 East 11th Street, Austin, Texas 78701

Printed by TRC Environmental Corporation

\section{jointly published by the}

Texas Department of Transportation

Environmental Affairs Division

Archeological Studies Program

Nancy A. Kenmotsu, Ph.D., Supervisor

Archeological Studies Program Report No.48

A. McGraw, Series Editor

and

TRC EnvironmentalCorporation

TRC Technical Report 35398

505 East Huntland Drive, Suite 250

Austin, Texas 78752 


\section{EXECUTIVE SUMMARY}

Staff Archeologists from the Environmental Affairs Division of Texas Department of Transportation discovered buried cultural resources that constitute archeological site 41JS102, in June and July 2001 at the proposed location of a bridge replacement over Noodle Creek in Jones County, Texas. Shovel testing and backhoe trenching revealed cultural material at $65 \mathrm{~cm}$ below the surface. Following this discovery the Texas Department of Transportation made recommendations to the Texas Historical Commission to assess site 41JS102 and they concurred. In September 2001 archeologists from the Texas Department of Transportation initiated the site assessment phase. Landowner complications halted that work before completion. Subsequently, TRC Environmental was provided a Work Authorization under an existing general services contract to complete the assessment of 41JS102 in December 2001. The fieldwork consisted of the hand excavation and documentation of eight 1 by $1 \mathrm{~m}$ test units and the digging and documenting of six backhoe trenches. Limited and scattered historic artifacts were recovered from the upper parts of the two alluvial terraces (T0 and T1). A prehistoric component with quantities of lithic debitage and sparse burned rocks, limited stone tools and mussel shells, and one possible cultural feature were encountered in a sloping, but well defined 10 to $15 \mathrm{~cm}$ thick zone in the T1 deposits. The Principal Investigator recommended prehistoric site 41JS102 was eligible for inclusion in the National Register of Historic Places and as a State Archeological Landmark. However, the staff at Texas Department of Transportation disagreed with that recommendation and presented an opposing case to the Texas Historical Commission who concurred with the Texas Department of Transportation's recommendations. Consequently, no further archeological investigations will occur prior to the proposed development. 


\section{ACKNOWLEDGEMENTS}

TRC would like to thank Drs. G. Lain Ellis and Jim Abbott, and Mr. Jon Budd, all with the Environmental Affairs Division at Texas Department of Transportation for their various suggestions and directions concerning the investigations at 41JS102. Archeologist Jon Budd directed the initial field reconnaissance and Dr. Abbott conducted the initial geomorphologic documentation and interpretations. Dr. Abbott provided his written descriptions and interpretations to TRC prior to our field investigations. He also facilitated the submission of the charcoal for radiocarbon dating to Beta Analytic Inc. Jon Budd provided TRC with project engineering maps, plans and profile views, and existing test unit level forms, notes, and summaries from the initial testing. Other Texas Department of Transportation archeologists that participated in the initial site assessment activities included Allen Bettis, Michael Jordan, Jason Weston, and F. Jones. The local district office of the Texas Department of Transportation provided the backhoe and operator for this project. Mr. Jim Alexander, the landowner, is thanked for allowing backhoe access through his gates and across his land to conduct the backhoe trenching.

Project Archeologist Audrey Scott directed the field project under the over sight and direction of J. Michael Quigg who served as the Principal Investigator. Ms. Scott also wrote most of the interim report, and the environmental background section and contributed to other sections of the final report. Geomorphologist Grant Smith documented the trench profiles, drew the geomorphic figure, and wrote the geomorphic sections for the interim and final report. Shane Pritchard drew most of the figures. Roman Clem served as Crew Chief during the fieldwork and preformed the various laboratory duties including the washing, cataloging, data management, curation preparation, created several tables, conducted most of the general analyses, and prepared the materials for curation. Jeffrey D. Owens conducted the lithic analyses and wrote the debitage analysis section. Dr. Chris Lintz and Mr. Owens edited this report, which was then produced by Christine Torres. 


\section{TABLE OF CONTENTS}

Page

EXECUTIVE SUMMARY ............................................................................ii

ACKNOWLEDGEMENTS ............................................................................. iv

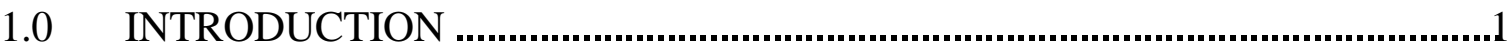

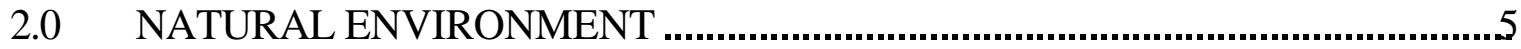

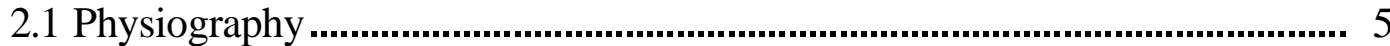

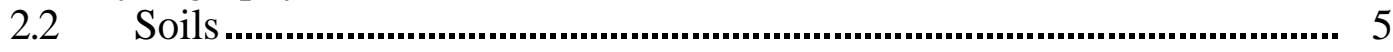

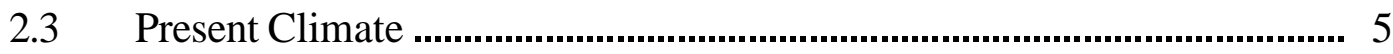

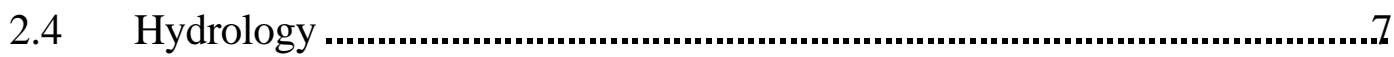

2.5 Flora and Fauna ................................................................................... 9

3.0 ARCHEOLOGICAL BACKGROUND AND CULTURAL HISTORY ...............11

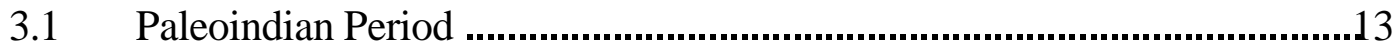

3.2 Archaic Period ............................................................................. 14

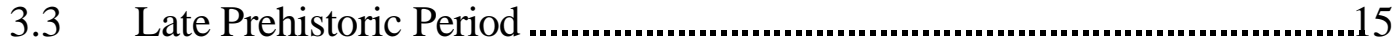

$3.4 \quad$ Historic Period ..................................................................................

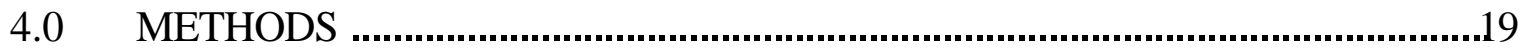

4.1 Geomorphic Field Methods …….....................................................19

4.2 Archeological Field Methods............................................................ 19

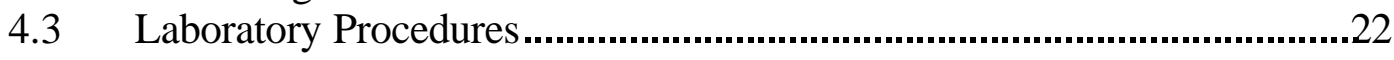

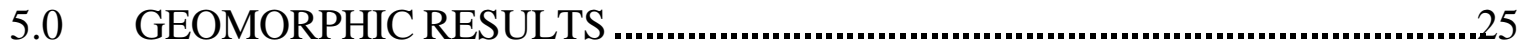

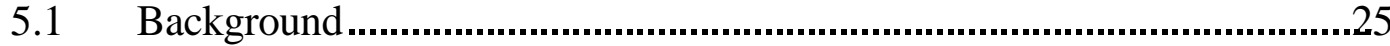

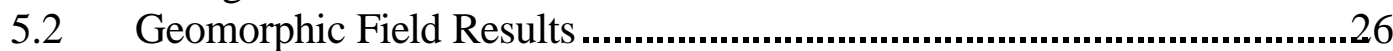

$5.3 \quad$ Geomorphic Interpretations ............................................................... 30

5.4 Regional Paleoenvironmental Considerations ........................................... 32

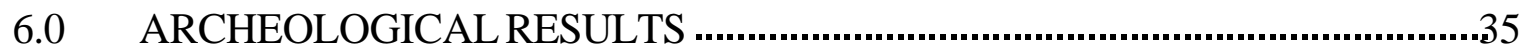

6.1 Cultural Materials from the T1 Terrace...................................................35

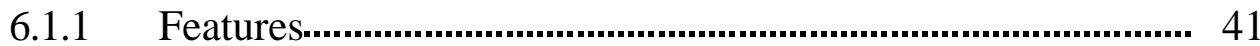

6.1.2 Material Assemblage .............................................................44

6.1.3 Spatial Distribution the T1 Terrace .........................................59

6.2 Cultural Materials from the TO Terrace.....................................................60

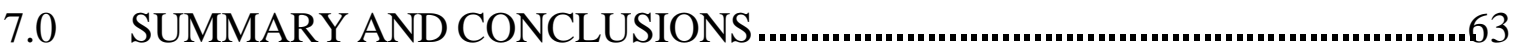

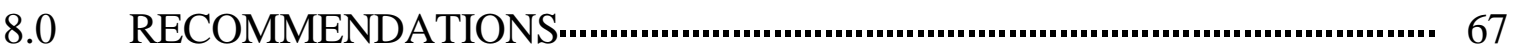




\section{TABLE OF CONTENTS - (Continued)}

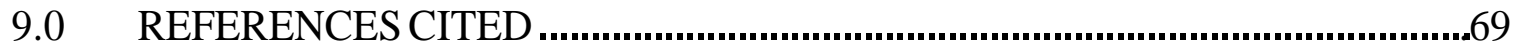

$10.0 \quad$ GLOSSARY OF TECHNICAL TERMS …….................................................77

APPENDIX A: Radiocarbon Results

APPENDIX B: Texas Department of Transportation Letter to the Texas Historical Commission 


\section{LIST OF FIGURES}

Page

Figure 2-1 Physiographic Region Surrounding the Site Area ......................................6

Figure 2-2 Vegetation Across the T1 Terrace at 41JS 102 ...........................................8

Figure 4-1 Project Development Zone Showing the Relationship of the

Vegetation and Archeological Investigation Areas on Northwestern

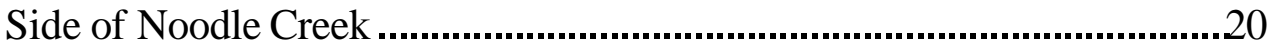

Figure 5-1 Generalized Stratigraphy Observed at 41JS 102 …....................................27

Figure 6-1 Lithic Debitage and Burned Rock Count Distribution for Proximal T1

(Units 1 and 6) and Medial T1 (Units 2 and 5) Settings at 41JS102 ........39

Figure 6-2 Lithic Debitage and Burned Rock Count Distribution for Distal T1

Setting (Units 3, 7, and 8) at 41JS102 .................................................. 40

Figure 6-3 Plan Map and Profile of Feature 1 in Test Unit 8. 41JS102 .....................42

Figure 6-4 Profile of Test Units 3, 7, and 8 Indicating the Buried Cultural Component..........................................................................................43

Figure 6-5 Plan View of Feature 1 in Test Unit 8, 41) s102, Showing Zephyr Point in Situ..................................................................................43

Figure 6-6 The Zephyr Dart Point (\#028-5) from 41JS102 ..........................................44

Figure 6-7 Selected Artifacts from 41JS102 ...........................................................46

\section{LIST OF TABLES}

Table 6-1 Distribution of Artifacts by Test Unit and Depth Grouped by Terrace Placement at 41JS102 ................................................................

Table 6-2 Metric and Non-metric Attributes on Edge Modified Flakes.....................49

Table 6-3 Debitage Types by Raw Materials.....................................................50

Table 6-4 Distribution of Debitage in Test Units at 41JS102 ….............................5.

Table 6-5 Burned Rock Data from 41JS102 ….....................................................58 


\subsection{INTRODUCTION}

Archeological investigations were undertaken at a bridge crossing over Noodle Creek in Jones County, about 48 k m (30 miles) northwest of Abilene, in north-central Texas. These investigations were in response to Texas Department of Transportation (TxDOT) plans to straighten the approach and replace the bridge on County Road (CR) 347 where it crosses Noodle Creek. TRC staff, under a specific work authorization of an existing contract to the Environmental (ENV) Affairs Division of TxDOT completed the eligibility assessment of site 41JS102 that was initiated by TxDOT archeologists following their site discovery investigations.

County Road 347 existed prior to the passage of the National Historic Preservation Act of 1966 (PL-89-665, as amended), the Department of Transportation Act of 1966 (PL 89-670), or the Antiquities Code of Texas (as incorporated into Title 98, Chapter 191 of the Natural Resources Code of Texas). Consequently, no cultural resource investigations had been undertaken at this locality in conjunction with the original road and bridge construction. Under these current laws, it is now a requirement that before further construction can occur, the development zone must be inspected to determine if cultural resources might be impacted. To facilitate the implementation of the law TxDOT operates under a Programmatic Agreement (PA) with the Texas Historical Commission (THC), Advisory Council on Historic Preservation, and Federal Highways Administration, and a Memorandum of Understanding (MOU) between TxDOT and the THC. These agreements stipulate that highway development areas similar to the Noodle Creek project are routinely investigated for cultural resources that would potentially be adversely affected by the development.

The proposed development will straighten the approach and install a new bridge over Noodle Creek and that will impact about 155 m (500 ft.) of CR 347 at the creek crossing. The terrain at the crossing involves a gradual slope toward the creek with about a $3 \mathrm{~m}$ (10 ft.) drop at the creek edges. The current $19 \mathrm{~m}$ (63 ft.) wide right-of-way (ROW) will be expanded to about $30 \mathrm{~m}$ (100 ft.) wide within the proposed $155 \mathrm{~m}$ long development section. The planned development will mostly impact natural deposits east of the existing ROW for a distance of about $8 \mathrm{~m}(25 \mathrm{ft}$.). Rural agricultural fields and pasture lands with minimal elevation changes surround the development zone.

TxDOT archeologist Jon Budd conducted the cultural resource inventory; at the Noodle Creek Bridge crossing that resulted in the discovery of the site on June 6 and July 10, 2001. At that time prehistoric archeological site 41JS102 was discovered buried in the alluvial creek deposits within the northeastern quadrant of the proposed development zone. The cultural deposits are bounded on the south by Noodle Creek and on the west 
by the existing CR 347. The north and east site boundaries extend beyond the proposed development area into lands privately owned by Mr. Jim Alexander. Intact prehistoric cultural materials from one shovel test and two backhoe trenches were detected. With the discovery of intact cultural deposits, TxDOT personnel recommended site testing to determine site integrity and significance. The THC concurred with the need and the plan for site assessment to determine if site 41JS102 contained sufficient integrity and cultural information to be eligible for inclusion in the National Register of a Historic Places (NRHP) and/or warrant designation as a State Archeological Landmark (SAL).

Subsequently, TxDOT archeologists Jon Budd and geomorphologist Dr. Jim Abbott initiated an archeological assessment program in September of 2001. The assessment included the digging of six backhoe trenches and the excavation of two test units (TUs 1 and 2). But landowner complications halted that work before it could be completed. Units 1 and 2 were closed at depths of only $60 \mathrm{cmbs}$ and artifacts recovered to that point were placed in plastic bags and left in the bottoms of the excavation units. The units were lined with black plastic and backfilled. Following the resolution of the landowner concerns, TRC was given a work authorization to complete the site assessment fieldwork. J. Michael Quigg of TRC served as Principal Investigator on the Texas Antiquity Committee Permit No. 2746 for this assessment program. In December 2001, TRC staff completed the site assessment. An interim report on the findings from the field assessment phase including recommendations for future investigations was submitted in January 2002 (Scott et al. 2002). TxDOT archeologists did not agree with our (TRC's) recommendations that the portion of the site within the proposed ROW meets evaluation Criterion D of the NRHP eligibility. TxDOT personnel believed that subsurface testing demonstrated that: 1) the archeological deposits within the ROW have been disturbed (due to overprinting), and 2) are chronologically problematic due to the lack of radiometric data consistent with the presumed age of the dart point. These problems would compromise any successful effort to discern cultural traits in further studies (Kenmotsu 2002). Therefore, TxDOT recommended that those deposits within the ROW did not contain archeological deposits that are eligible for listing on the NRHP or for designation as a SAL (Appendix B). The State Historic Preservation Officer (SHPO) concurred with TxDOT's recommendations and no further investigations were conducted in the proposed development area. Following that decision, a final report was prepared on the findings from the site assessment phase without any further analytical documentation such as radiocarbon dates, lipid residue analysis, or sediment studies. This document is the final report concerning the discovery and assessment of site 41JS102. 
This final report provides a brief background of the natural environment, the archeological background and cultural history for this vicinity, and presents the field methods involved for the site discovery and assessment. This is followed by the results of the geomorphology and archeology investigations at 41JS102. Next, the summary and conclusions from the archeological investigations are presented followed by TRC's sitespecific recommendations to the cultural resource managers concerning future investigations. References cited and a glossary of technical terms is the final two sections. Two appendices are provided for specific details on the radiocarbon results and TxDOT's recommendations to the THC. 


\subsection{NATURAL ENVIRONMENT}

\subsection{Physiography}

Jones County is near the southern end of the Rolling Plains physiographic province, often referred to as the Permian Redbeds (Figure 2-1). This long plain stretches from Kansas into north Texas and was never glaciated. The area is about $526 \mathrm{~m}(1,725$ ft.) above mean sea level with local relief varying some $30 \mathrm{~m}$ (110 ft.). The project area is underlain by the Permian-aged Clear Fork Group, which consists of mudstone, limestone, dolomite, sandstones, and siltstone. Quaternary alluvium caps the Permian age formations. Erosion of the Cretaceous, Tertiary, and Quaternary strata has created an expanse of low relief with undulating, and rolling hills dissected by numerous creeks and rivers. Some $280 \mathrm{~km}$ (175 miles) to the west is the Caprock Escarpment that creates the eastern margin of the Llano Estacado or Southern High Plains. The area between the edge of the Llano Escarpment and the Rolling Plains is an area of rugged canyonlands. The drainage divide between the Colorado and the Brazos basins is some $48 \mathrm{~km}$ (30 miles) south of the project and defined partially by the Callahan Divide. The Callahan Divide is an erosional remnant of prominent hills composed of Lower Cretaceous-age Antlers Sand, capped by Edwards Limestone that overlying the Comanche Peak Limestone and Walnut formations. Chert is present in the Antler sands and in the Edwards limestone.

\subsection{Soils}

The area surrounding the project is mapped as Rowena-Olton association that is characterized as deep, well drained, nearly level to gently sloping clay loams (Rogers et al. 1972). These soils are calcareous. The actual site area is mapped as Spur soil, broken with surface layers that are reddish-brown, calcareous loam overlying similar soils with more clay strata of fine sandy loams. These soils occupy all areas of recent deposition associated with Noodle Creek and other creek and river settings in the vicinity. The typical Spur clay loam exhibits an A-Bwl-Bw2-Bw3 profile with minimal carbonate development.

\subsection{Present Climate}

Jones County is characterized by a semiarid climate with hot summers and mild winters. The weather is mostly warm and dry, with June to August being the hottest months and December and January the coldest months. Cold fronts passing through during the winter months can cause rapid daily fluctuations in temperature and humidity. Average humidity in this area varies from 38 to 75 percent. Wind is steady, usually from the south and averages 17.7 to $25.8 \mathrm{~km}$ per hour (11 to $16 \mathrm{mph}$ ), with winds as strong as 


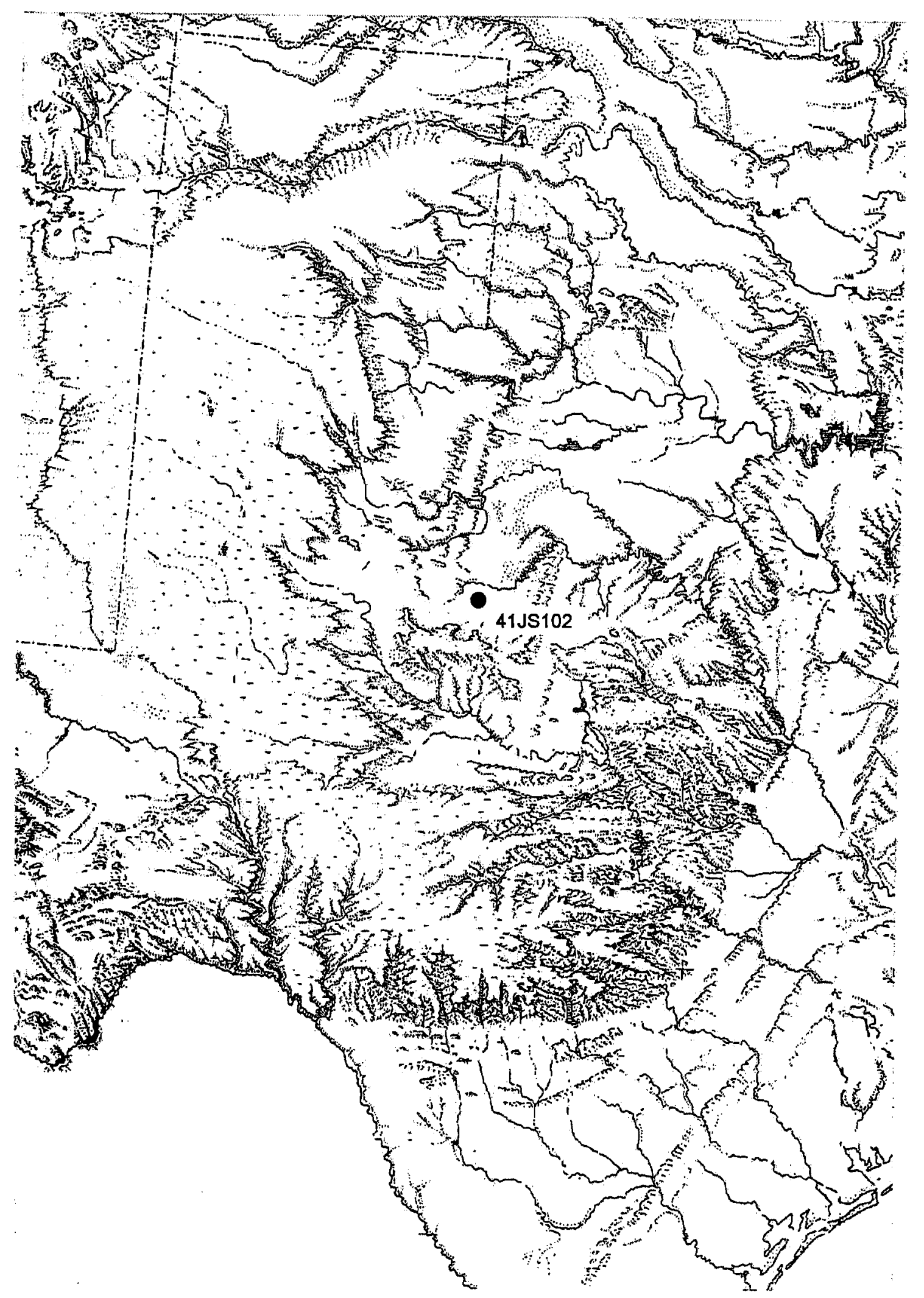

Figure 2-1. Physiographic Region Surrounding the Site Area 
$113 \mathrm{~km}$ per hour (70 mph) recorded in some areas of this region (Kingston 1991). The strongest continuous winds occur during March and April. The growing season is 223 days.

Rainfall is generally higher in the Rolling Plains than in the adjacent Llano Estacado and Caprock Canyonlands areas. Annual precipitation in the last thirty years has averaged almost $60.9 \mathrm{~cm}$ (24 inches). Yearly snowfall averages over $12.7 \mathrm{~cm} \mathrm{(5}$ inches).

Approximately 70 percent of annual precipitation occurs between May and October. This comes mostly in the form of convective thunderstorms of varying quantity and intensity. Most of the spring and early summer storms arrive with intense conditions. The evapotranspiration rates are relatively high year-round, especially in the summer when evaporation rates often exceed those of precipitation. These conditions tend to cause periodic droughts alternating with floods during heavy rains. The inconsistency of weather, especially precipitation, is a main characteristic of the region, and may have influenced human settlement and subsistence patterns in this area.

\subsection{Hydrology}

Site 41JS102 is on the north side of Noodle Creek, a small northeast flowing tributary of the Clear Fork of the Brazos River. Noodle Creek parallels Sweetwater and Cottonwood creeks further west and Bitter and Cottonwood creeks to the east that all feed into the Clear Fork. The Clear Fork is the southern most tributary to the Brazos River that drains primarily eastward across the Rolling Plains and then northward, and eventually southeastward to the Gulf. These waters originate further south and west in the Caprock Canyonlands below the escarpment of the Llano Estacado.

Surface water is usually present in numerous stream channels associated with major river systems crossing the Rolling Plains. The location of springs and seeps correlate with surface geology and topography, and therefore fairly predictable. The flow from small or minor springs tends to be strongly influenced by the short-term fluctuations in precipitation. In the Rolling Plains, springs come primarily from two sources; Quaternary alluvium and Permian aquifers. Springs in the Rolling Plains are not as widely or densely distributed as they are in the Caprock Canyonlands area. Springs are still relatively abundant, but have poor quality water. The widespread presence of exposed and subsurface Permian strata containing high quantities of gypsum and salts result in very high salinity and dissolved solids. 


\section{$2.5 \quad$ Flora and Fauna}

Most of the Rolling Plains is a mixed-grass prairie and mesquite savanna vegetation community (Blair 1950; Kuchler 1964). This area is characterized by fairly dense to open stands of grasses with some shrubs and low trees (Figure 2-2). Buffalo grass (Buchloe dactyloides) dominates the area, with bluestem (Bothriochloa sp.) and grama (Bouteloua sp.) grasses are also well established. Mesquite (Prosopis glandulosa) and other arid environment shrubs and trees are present. Along the creeks and rivers, larger trees such as elm (Ulmus sp.) and cottonwood (Populus sp.) are sometimes present. Riverine environments in the Rolling Plains tend to be fairly well-timbered, especially along the canyonlands. The dominant vegetation cover of the non-disturbed area of the proposed development zone consists of mesquite, prickly pear (Opuntia engelmannii), tasajillo (Opuntia leptocaulis), allthorn (Castela texan) and sparse grasses.

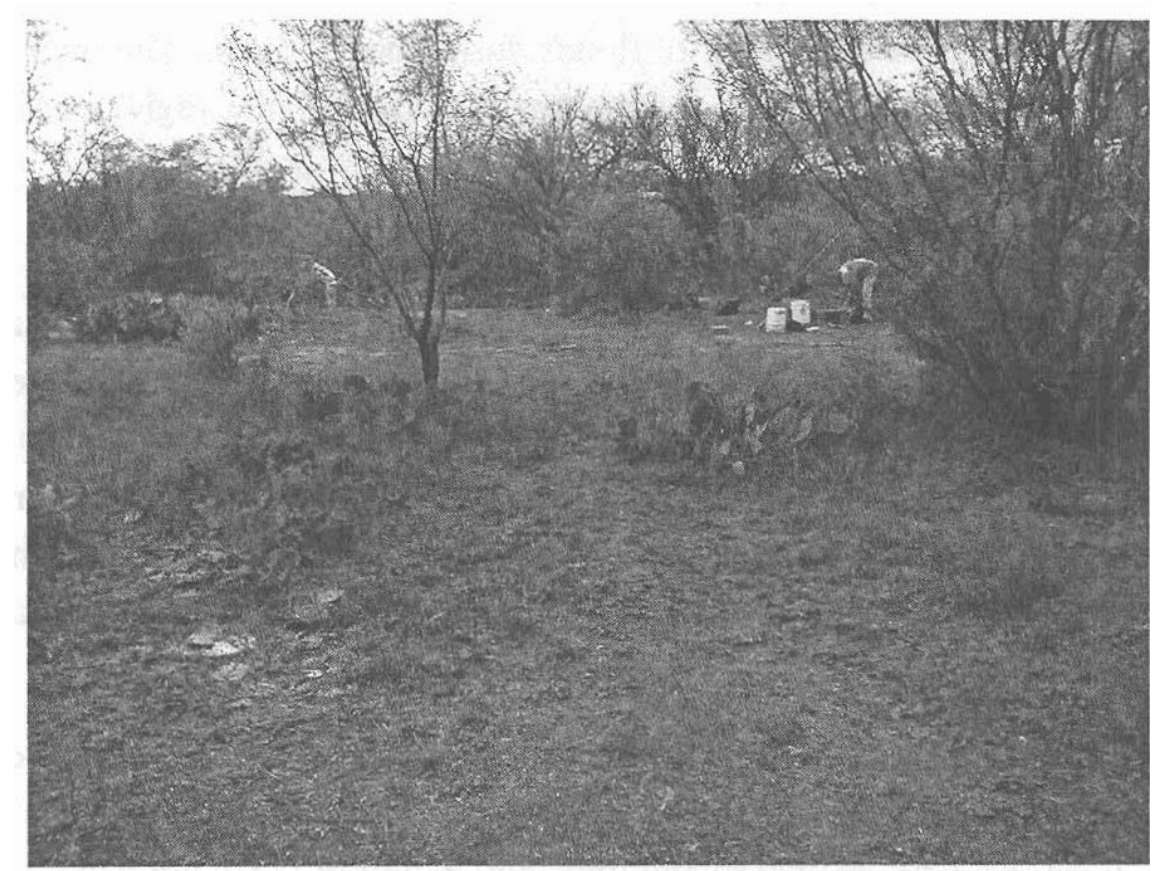

Figure 2-2. Vegetation Across the T1 Terrace at 41SJ 102

Faunal resources available to prehistoric occupants in the area consisted of large mammalian game, as well as birds, fish, and small mammals. This region contains at least 57 species of mammals, 36 species of snakes, 15 frog or toad species, 16 lizard species, eight turtles, and one salamander species (Blair 1950). At least 317 avian species, 35 species of fish, 18 species of mussels, and even a few crustacean species may have been available (Lintz et al. 1993). 
Large game consisted mostly of pronghorn, and both mule and whitetail deer. Pronghorn have been reported in the area, and may have been a more stable resource prehistorically than now. In prehistoric times bison likely flourished in the Rolling Plains in large herds for most of the year, providing a fairly stable resource for prehistoric human consumption. During the coldest months of the year, December through February, it is likely that the bison split into smaller herds and sought refuge in the sheltered canyonlands and riverine areas along the Plains margins (Flores 1990; Roe 1972). 


\subsection{ARCHEOLOGICALBACKGROUND AND CULTURAL HISTORY}

The archeological investigations in the Abilene area go back to the 1930s with the work by Dr. Cyrus N. Ray, a Doctor of Osteopathy by training and avid avocational archeologist from Abilene. Dr. Ray was one of the founding members of the Texas Archaeological and Paleontological Society in 1928 now known as the Texas Archeological Society (TAS) (Tunnel 2000). He published some 66 articles over the years in the Bulletin of the Society and contributed much to the regional archeology (Ray 1929, 1935a, 1938). Dr. Ray teamed with Ted Sayles, also from Abilene and another founding member of the Society, and they contributed to the archeology of the region (Ray and Sayles 1941). These early enthusiasts clearly demonstrated that the region contained a wealth of archeological resources. Much of the early materials came from poorly documented surface collections and before radiocarbon dating was available. Consequently, the cultural complexes created by these materials were not well developed and have not been integrated into the more recent archeological literature.

Two Archaic sites, the Gibson and Hodges sites in the Abilene vicinity, were prominent sites in the region. Both were terrace sites with exposed cutbanks and stratified deposits. They yielded quantities of Archaic materials and possibly other materials from other time periods that included hearths, chipped and ground stone tools, and lots of lithic debris and burned rocks (Ray 1940; Wheat 1940; Crook 1955). The Gibson site and vicinity on Elm Creek in Taylor County was often viewed as the type site for Ray's (1938) "Clear Fork culture complex", but most of the cultural materials recovered from eroding cutbanks and not excavated context. The Hodge site on the Clear Fork drainage in Jones County was excavated in 1940 with support of the Works Progress Administration (WPA), which documented the occurrence of deep deposits, roughly $10 \mathrm{~m}$ (30 ft.) of stratified prehistoric occupations that contained hearth features but few artifacts (Wheat 1940). The "Clear Fork cultural complex" included a variety of projectile points such as triangular Tortugas like and Nolan types, a unifacial gouge/planner, and an assortment of other tool forms. In a review of the Ray's sites and data to 1955, Cook (1955) stated that the nomenclature and interpretation are the main causes of confusion concerning the artifacts and geologic formations.

Ray (1937, 1935b, 1939) also excavated many burials in the region including those in stone-slab cists. Flexed burials and cremations were identified but few contained grave goods. In the adjacent county of Shackelford, an extensive surface site along a small creek also yielded some 18 burials. Some were in rock cists (Forrester 1951). 
Sayles (1931) identified the occurrence of flint sources in the Elm Creek valley of the Callahan Divide in Taylor County south of the project area. He discusses the general source of the flint cobbles as eroding from the limestones that make up the middle of the Lower Cretaceous series. The colors range from "a lead or blue slate to nearly black, while some is gray, speckled or mottled with lighter or darker colors" (Sayles 1931).

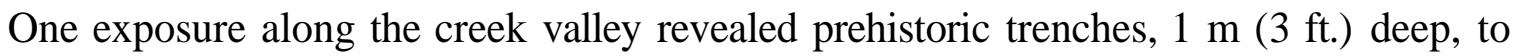
mine the raw materials from at least $2.5 \mathrm{~m}$ (nearly $8 \mathrm{ft}$.) thick zone. Large chert cobbles were extracted directly from limestone beds. Some reduction of the cobbles was conducted at the quarry source and some was also done at nearby campsites. "Tons of flakes, and hammerstones, scrapers, hearths and other evidence of occupation nearby extended continuously for at least three miles along Elm Creek" (Sayles 1931).

In the early 1970s the Texas Historical Commission (THC) conducted excavations at the Paleoindian site of Adair-Steadman (41FS2) in adjacent Fisher County. This Folsom campsite yielded significant technological data on the manufacturing process employed in the production of the fluted Folsom projectiles (Tunnell 1975). Large quantities of lithic debris were recovered and appear to represent the manufacturing stages of a highly specialized tool kit. The tool stone was very abundant and of a very high quality (Tunnell 1975).

In 1971 the THC under the direction of Robert Mallouf also conducted extensive inventories in Fisher and Jones counties centered on the Clear Fork of the Brazos River just down river from Sylvester. Some 33 sites and one excavated hearth feature were documented. The materials from those inventories, more than 8,500 pieces, were finally analyzed and presented in a thesis by Virginia Wulfkuhle in 1986. Charcoal from the salvaged hearth yielded two acceptable radiocarbon dates that fall within the range of 680 to 380 B.P. (Wulfkuhle 1986). The surface derived assemblages represented the entire time range of known occupations across the region. The collections include numerous Paleoindian points such as Midland, Plainview, Angostura; Archaic projectiles including Nolan, Martindale, Bulverde, Bell, Marcos, Frio, and other types have close affinities to the central Texas region; and the Late Prehistoric projectiles including Washita, Prediz, Fresno, Harrell and others (Wulfkuhle 1986).

Over the years the Abilene region and its archeological remains have been placed in different geographical regions. Early on, Krieger (1946:122-123) called it an illdefined area of north-central Texas. In the syntheses by Suhm et al. (1954) the region was split among the Panhandle Plains, north-central, and central regions. Subsequently, Weir (1976) and Prewitt (1981) excluded the Abilene area when developing their central Texas chronologies. In 1982 the statewide planning document published by the THC 
(Brown et al. 1982) showed the Abilene area as part of the Lower Plains region. Since that time, most authors recognized this region and classification, with the Southern High Plains to the west, the North Central Texas region to the east, and Central Texas region to the south. However, Perttula (1995) labels this region as part of West Central Texas.

Numerous archeological surveys and small testing investigations have been conducted in the broader region now classified as the Lower Plains and include such large projects as the Brazos Natural Salt Pollution Control project (Thurmond et al. 1981), Ballinger Reservoir (Guffee 1989) and South Bend Reservoir (Saunders et al. 1992). However, major excavations and the subsequent reporting of that data are nearly nonexistent for the Abilene region. The Lower Plains or Rolling Plains is one region that was not synthesized in the latest overview of Texas Archeology (Perttula, editor 1995) and this probably reflects the limited availability of published excavation data. The one major mitigation project is the Lake Allen Henry project northwest of Jones County in Garza and Kent counties. I have chosen Boyd's (1997) summary for the Lake Allan Henry project as the foundation from which much of the following is extracted and or summarized. Investigations at Lake Allan Henry represented primarily the last 4,000 years and include the Late Archaic and the Late Prehistoric, and Historic periods. Cultural manifestations prior to that will be based on the summary by Hofman et al. (1989).

The Lower Plains as in the adjacent regions is divided into four broad time periods, the Paleoindian, Archaic, Late Prehistoric and Historic periods. A brief synthesis of the key characteristics of these four periods is presented.

\subsection{Paleoindian Period}

The general time period is from about 11,500 to around 8000 B.P. The key characteristic is considered the lanceolate projectiles that include types such as Clovis, Folsom, Midland, Plainview (Milnesand) and Agate Basin. These points were used to tip the shafts of spears. Generally, the economic reliance was thought to have focused primarily on big game hunting, although more recently a more diverse subsistence base has come to light (Johnson 1987). The earliest groups, the Clovis period are though to have had subsisted upon diverse and extinct big game, but the groups after about 11,000 years ago focused on extinct bison as the principal animal resource. Given a mobile food resource such as bison, it is believed that most Paleoindian populations were constantly on the move following the game animals and thus very nomadic hunters. The AdairSteadman site in adjacent Fisher County is a significant Folsom campsite that was excavated and is representative of the Paleoindian occupations in this region (Tunnel1 1975). The Lone Wolf Creek site near Colorado City yielded some of the earliest 
Paleoindian points (Plainview type) in direct association with articulated animal bones of an extinct bison (Wormington 1957). Although many Paleoindian projectile points have been recovered in the region very few well excavated and reported Paleoindian sites have completed in Texas. One such site, the Lubbock Lake site, provides a wealth of information concerning this period including the data on the paleoenvironment (Johnson 1987). Sites dating to this period lack the large concentrations of burned rocks and burned rock features that are common in the following Archaic period.

\subsection{Archaic Period}

Following the Paleoindian period, the long Archaic extended from about 8500 to about 1500 B.P. This period is generally divided into shorter time units that are labeled as Early, Middle, and Late Archaic. In this region, few sites of the Archaic period have been intensively excavated and reported upon. The Archaic population appears to have diversified their subsistence utilizing an array of plant and animal resources. Along with this diverse economy came the intensive use of numerous and diverse burned rock cooking features. The massive burned rock middens common in central Texas are less common in the lower Plains region (Wulfkuhle 1986). The projectile point forms also changed to smaller, stemmed and notched forms that were used to tip dart shafts used with the atlatl. Large herds of bison were apparently not as frequent as during Paleoindian times and the plant foods more localized, therefore the groups were thought to have been more regional. Along with more regional economics came an apparent increase in population size and density. Ray's (1938) Clear Fork Culture and Sayles' (1935) Abilene Branch are dominated mostly by Archaic materials.

The Early Archaic is considered to have occurred from about 8500 to 5000 B.P. This is a period generally associated with the mid-Holocene Altithermal or Atlantic interval, a dry and warm period (Hofman 1989:45). The Early Archaic sees a number of new tool forms including grinding tools and gouges, but the latter may have appeared even earlier. The Middle Archaic is considered to be from about 5000 to 3000 B.P. with the Late Archaic following that between about 3000 to 1500 B.P. The precise timing of these divisions is not well established because so few Archaic sites have been excavated and radiocarbon dates from good context are infrequent. Late Archaic bison kill sites are known from the northwestern part of Texas along the western margins of the Rolling Plains (Hughes 1977). Bison were also recovered from the Archaic events at Lubbock Lake (Johnson 1987). It is not clear which complexes from the adjacent High Plains or Central Texas regions utilized the Abilene region. No matter who was in the region during those times, the populations were probably adapted to the effects of the dry Altithermal period. 


\subsection{Late Prehistoric Period}

This covers a period from about 1500 B.P. to about 500 B.P. when the European exploration and settlement began to occur in the region. This period sees the introduction of the bow and arrow as the principal weaponry system and the beginning of pottery making. Agriculture is also considered a major event during this time, but the evidence for this subsistence practice is quite limited in this region. It is also not clear as to when these different traits came to the Abilene region, and they probably did not all happen simultaneously. It is assumed that these technological innovations had profound affects on the regional populations.

Most researchers divide the Late Prehistoric period into early (1500 to 1000 B.P.) and Late (1000 to 500 B.P.). For the early Late Prehistoric subperiod in the northwestern region of Texas, a number of broad cultural complexes have been identified including the Palo Duro and Plains Woodlands. The Blow Out Mountain complex is south of Jones County and is poorly understood. These known complexes surround the project region and it is yet to be determined which of these, if any, are represented in and around Abilene.

The projectiles representing the earlier subperiod are generally small forms with a variety of hafting characteristics predominated by side, corner, and basal notching, a combination of these, along with small, narrow stem forms. The known material assemblages show relatively limited diversity between complexes. The most characteristic aspect for most cultural complex identifications is the different styles of projectiles and the ceramic assemblage.

The Palo Duro complex is quite distinctive with its easily distinguished ceramic assemblages, house forms, burials, and feature types. This complex appears to represent Mogollon groups moving northeastward out of southeastern New Mexico as represented by a few scattered sites in the Brazos drainage basin (Willey and Hughes 1978; Cruse 1992; Boyd 1995). A number of different types of sites have been recognized and include burials, open campsites, rockshelters, and base camps. Based on the different material assemblages and feature types the sites appear to represent different durations of occupations and different activities (Boyd 1997). This complex appears to represent semi-sedentary groups. Information concerning seasonality is sparse and is mostly circumstantial. Currently the site distribution appears to be concentrated more below but next to, the escarpment between the southern High Plains and the Rolling/Lower Plains. These sites represent occupations from about 1450 to 750 B.P.

The Lake Creek complex is viewed as a Plains-Woodland manifestation. Small comer-notched arrow points, cord marked ceramics, and open sites characterize this 
complex. The subsistence practices are not well known, but bison appear to have been scarce. The occurrence of ground stone implements indicates more reliance on plants than animals. Agricultural practices are not evident thus far for the complex but it might have occurred. Information concerning the seasonality and settlement patterns and other types of data are scattered and limited, making clear and concise statements difficult to summarize. For this general region, the Lake Creek woodland complex appears more focused on plant resources and therefore it is assumed that more scheduling is required to obtain them. The high mobility of the population creates many short-term campsites.

The later part of the Late Prehistoric period is again not well understood for the Abilene region. Identified complexes in the adjacent regions include the Garza complex to the northwest, the Henrietta to the east, and the Toyah to the south. The Abilene area may have seen cultural influences from all or none of these known complexes. Without major excavation reports, it is too early to speculate on which and how different groups used this region.

\subsection{Historic Period}

Excavated archeological data is also scarce for the Historic period, beginning with the arrival of the first Europeans exploring the broad unknown territories. This generally reflects a period from about A.D. 1540 to the present. The Indian groups include the Comanche, Apache, Wichita, and Teya groups (Castaneda 1904; Hammond and Rey 1940; Bolton 1949; Hodge and Lewis 1984; Boyd 2001). Identified sites in the region have not been assigned to these native groups and the material cultural left behind may not be characteristic enough to actually assign a cultural assemblage to a named group. Again, the lack of major excavations has not provided the data necessary to address which groups were using this region at the time of European settlement.

Between about A.D. 1820 and 1860, the nonnative Indian population was widely scattered and consisted mostly of traders and soldiers. Fort Phantom Hill, on the eastern side of Jones County, was built to help control the hostilities between the Native Americans and the Angelo American groups. The Fort was constructed in A.D. 1851 and abandoned in November 1853. A few years later this location also served as a way station along the Overland Mail route and the Butterfield Stagecoach line. Today, Fort Phantom Hill is one of the most pristine historic sites and contains more than a dozen stone chimneys and three stone building remain in this 22-acre reserve (www.fortphantom.org,May 22, 2002). Fort Phantom Hill was also the site of limited archeological excavation by a team from Texas Tech University lead by Dr. Grant Hall in A.D. 1998. Three building foundations including a kitchen, a mess room, and a sergeant's room were investigated. The archeological work was conducted in 
conjunction with archival and historical research that also provides important information concerning this historic fort (Freeman 1999).

Following the Civil War (A.D. 1860 to 1865) white settlements increased rapidly (Hays, et al. 1989). Buffalo were still in the region until about A.D. 1880, but Anglo hunters killed most of the buffalo over a ten-year period between about A.D. 1870 to 1880 for commercial purposes (Freeman 1990a). The city of Abilene was founded in A.D. 1881 with the construction of the Texas and Pacific Railroad. Many historic sites undoubtedly exist throughout the region, but no formal systematic inventories are known. When historic sites are inventoried two historic context: "Buffalo Hunting on the Rolling Plains, 1874-1879," under the thematic heading of "Natural Resource Exploitation and Development" and "Ranching on the Western Rolling Plains, 1877-1945," under the thematic heading of "Agriculture in Texas" may help establish criterion for evaluating those properties (Freeman 1990a, 1990b). 


\subsection{METHODS}

\subsection{Geomorphic Field Methods}

The geomorphic/geoarcheologic investigation at 41JS102 consisted of examination of backhoe trenches, hand dug test units, and pedestrian examination of the surrounding terrain. Field descriptions follow standard sedimentologic and pedogenic procedures established by the Soil Survey Staff (1962, 1975), Krumbein and Sloss (1963), Gile et al. (1966), Reineck and Singh (1980), Birkeland (1984), Birkeland et al. (1991), and Waters (1992). Field investigations were recorded on standardized profile exposure forms.

At the time of our investigations, the sediments tended to be wet from recently melted snows. This high moisture content tended to obscure the stratigraphic boundaries in the upper portions of our profiles, particularly those between weak A horizons in the upper sediment unit. These wetter conditions may, in some cases, have also altered the visibility of some characteristics that may have been easier or harder to see during the previous investigations by Abbott (n.d.) under drier field conditions.

Overall, the stratigraphy tends to be similar to that proposed by Abbott, but some minor variations occur. These variations may indicate differences in field conditions, slightly greater depths in some of the backhoe trenches, and/or differences in personal opinion regarding the strength or weakness of some soil characteristics. These differences are regarded as minor do not fundamentally effect the interpretation of the soil/sediment record of the site.

\subsection{Archeological Field Methods}

During the site discovery phase in June and July, 2001 TxDOT personnel investigated the northeastern development zone through the use of two backhoe trenches (BTs 1 and 2) and one 30 by 50-cm shovel test (Figure 4-1). Both trenches were orientated perpendicular to the existing roadway and located about $13 \mathrm{~m}$ apart on the higher, flat surface. The trenches measured about 3 to $5 \mathrm{~m}$ long by $1.2 \mathrm{~m}$ wide and $1 \mathrm{~m}$ deep.

The THC approved assessment plan for 41JS102 included the excavation of six backhoe trenches and the hand excavations of five 1 by $1 \mathrm{~m}$ units distributed across the project area. The hand-excavated matrix was to be screened through $6.35 \mathrm{~mm}(1 / 4 \mathrm{inch})$ wire-mesh screens. A geoarcheologist was to document all trenches.

In September 2001, TxDOT's personnel led by Dr. Abbott and Jon Budd initiated the site assessment program. At that time, the two previously dug backhoe trenches (BTs 


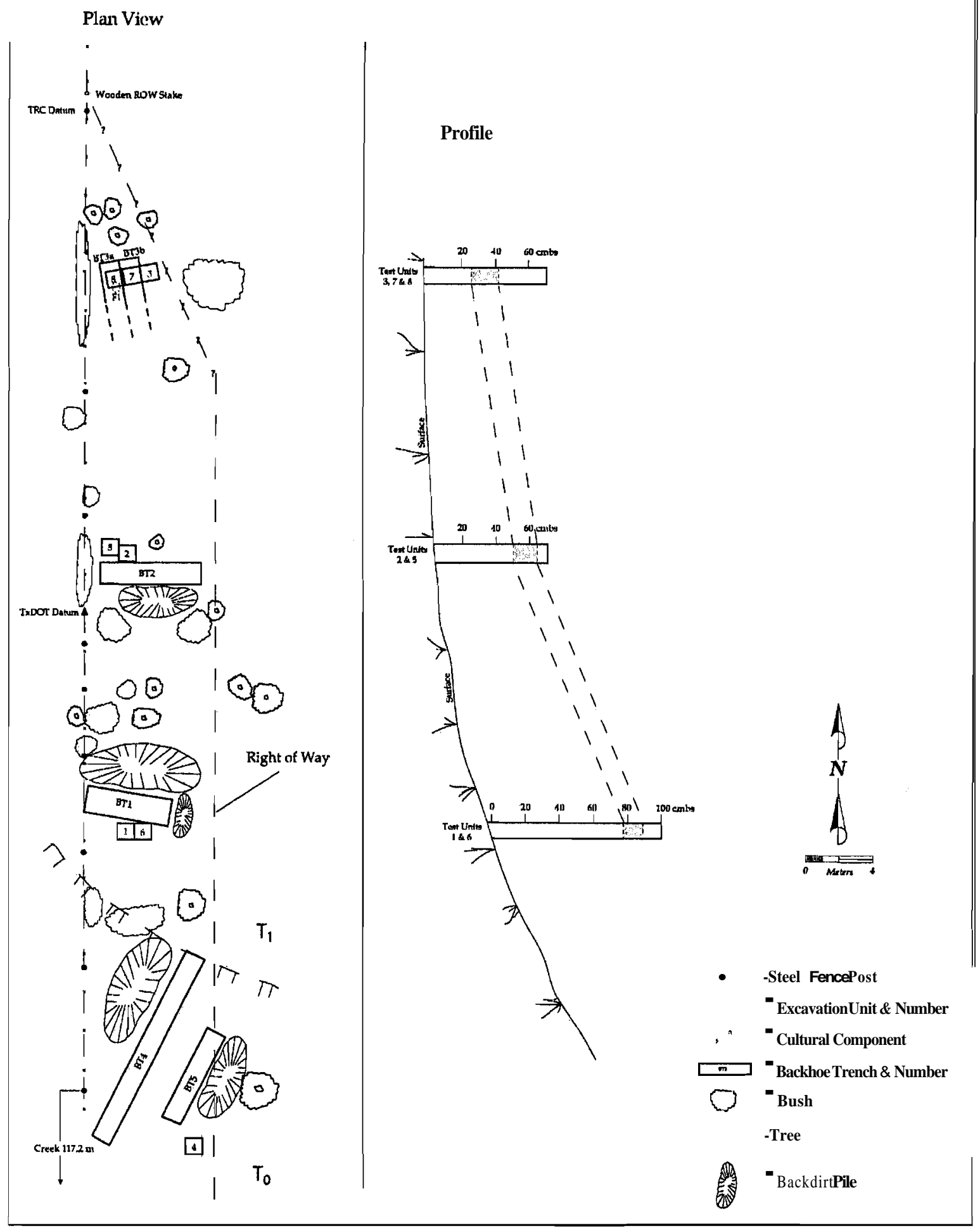

Figure 4-1. Project Development Zone Showing the Relationship of the Vegetation and Archeological Investigation Areas on Northwestern Side of Noodle Creek 
1 and 2) were re-opened and four additional trenches, BTs 3 through 6 were dug. Trenches 1 and 2 were dug into the T1 deposits near the middle of the development zone. Trenches $3 \mathrm{a}$ and $3 \mathrm{~b}$ were side-by-side scrapes into the $\mathrm{T} 1$ deposits initiated at the very north end of the development zone. These shallow scrapes were terminated just after excavation began since they encountered what appeared to be a cultural feature. Trenches 4 and 5 were dug just north of Noodle Creek and they crossed the sloping southern edge of the T1 terrace and on to the lower $\mathrm{TO}$ terrace. These five trenches were within the northeastern quadrant of the development zone. Trench 6 was in the northwestern quadrant and in a two-track road leading through a gate. Trenches $3 \mathrm{a}$ and $3 \mathrm{~b}$ were only 20 to $30 \mathrm{~cm}$ deep; with all other trenches more than $100 \mathrm{~cm}$ deep with a maximum trench depth was $1.6 \mathrm{~m}$. Trenching was

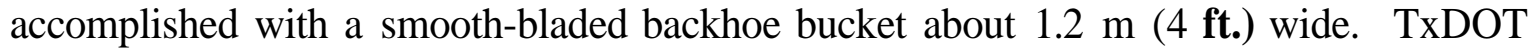
archeologists monitored the mechanical excavation and the release of the backdirt from the bucket. Each trench was examined, photographed, described using standard soil terminology, and schematic stratigraphic profiles were drawn (Abbott n.d.).

TxDOT archeologists hand-excavated two 1 by $1 \mathrm{~m}$ test units (TUs 1 and 2) to depths of about $60 \mathrm{~cm}$ below surface (cmbs). Unit 1 was excavated on the south side of BT 1 whereas Unit 2 was excavated on the north side of BT 2 (Figure 4-1). These were excavated in $10 \mathrm{~cm}$ arbitrary levels with the matrix screened through $6.35 \mathrm{mrn}$ mesh screens. Materials were bagged by level. Level records were completed for each excavated level. When TxDOT encountered landowner controversy the recovered materials were placed in the bottoms of the units, the units were lined with plastic, and then backfilled.

In December 2001 TRC staff continued the site assessment investigations. The original five-backhoe trenches (BTs 1 through 5) were reopened, as close to the original location as possible. In most cases, the re-excavated trenches were offset from the original trenches by no more than about $20 \mathrm{~cm}$. TRC geomorphologist, Grant Smith, cleaned, examined, and recorded the stratigraphy of each trench and correlated the stratigraphy with the other trenches and test units. Bulk matrix samples of about three liters were collected from BT 1 on the T1 terrace and BT 4 on the T0 terrace. Samples were collected from observed stratigraphic unit using thin $5 \mathrm{~cm}$ thick zones. Eleven samples were collected from BT 1 and ten were taken from BT 4.

The two TxDOT test units (TUs 1 and 2) started in September were reopened and hand-excavated to depths of 100 and $70 \mathrm{cmbs}$, respectively (Figure 4-1). Six additional 1 by $1 \mathrm{~m}$ units (TUs 3 through 8 ) were opened. All hand-excavated matrix from these test units were excavated in $10 \mathrm{~cm}$ arbitrary units and screened through $6.35 \mathrm{~mm}$ mesh screens. The units varied in depth from $45 \mathrm{cmbs}$ in TU 8 to $150 \mathrm{cmbs}$ in TU 4 with an 
average depth of $85 \mathrm{cmbs}$. Cultural materials discovered during excavations were collected, bagged by provenience. Level and depth provenience information was included on each level tag. Test Units 3, 7, and 8 were excavated in an east-west row in and adjacent to the shallow BT 3a and 3b to locate, access, and remove Feature 1 and associated materials immediately in the vicinity (Figure 4-1). Test Unit 4 was excavated at the extreme southern end of the northeastern quadrant, just a few meters north of Noodle Creek and into the $\mathrm{T} 0$ terrace deposits. Test Unit 5 was dug immediately on the west side of TU $\mathbf{2}$ on the north side of BT $\mathbf{2}$. Test Unit 6 was dug on the east side of TU 1 and the south edge of BT 1 . All test units but TU 4 sampled the T1 terrace deposits (Figure 4-1).

Information concerning each level excavated was recorded on a TRC level record form. Counts of the cultural materials by class, and other pertinent information about the soil texture and color, depths of the level, observations and general provenience information were entered on the level records. Burned rocks and other materials found in situ were plotted on the level records and their bottom elevations recorded. The recovered cultural materials were placed in zip-lock bags with provenience tags.

When a cluster of cultural materials was identified as a feature, the feature elements were left in place and carefully exposed to reveal their associations. After exposing and cleaning, each feature was photographed with black and white print and color slide film. The in situ feature materials were drawn on plan maps and the depths of each part of the feature were measured and recorded on the map. Cross-sections were made of the feature, but if nothing was observed in the cross-section profile, then nothing was drawn. The feature material was bagged and labeled separately from the general level according to material class (e.g. as lithic debitage, burned rocks, and charcoal, etc.). A sample of feature fill was often collected, bagged, and labeled.

\subsection{Laboratory Procedures}

Artifact processing began with washing and cataloging lithic materials and assigning numbers to the various samples recovered. The different artifact classes were subjected to various kinds of analyses. A set of predetermined attributes and metric variables for each material class were encoded on paper forms then entered into an electronic database. Metric variables and non-metric attributes were recorded for each identified tool. Matrix collected from Feature 1 was dried screened through 0.8 and 1.6 $\mathrm{mm}$ geologic screens of to retrieve any carbonized plant remains. Roughly $300 \mathrm{~g}$ of matrix from Feature 1 was curated without screening for possible future analyses.

The goal of the lithic debitage analysis was to determine the range of technological activities conducted by the prehistoric inhabitants related to chipped stone 
tool manufacture, maintenance, and discard. Therefore, the analyst emphasized the identification of bifacial and unifacial flakes, core flakes, rejuvenation flakes, and spatial distribution of flakes. The classification terminology used in this analysis is provided in the lithic debitage section.

Burned rocks represents natural rocks that were heated and cooled causing some rocks to crack, discolor, craze, or fragment. Most of the heated rocks were probably used in cooking activities, but a range of other behaviors could also use heated rocks. In the field, potential burned rocks were treated as other cultural artifacts and were collected, bagged with provenience tags, and returned to the laboratory for analyses. The burned rocks were identified as to material type (i.e. sandstone, limestone, etc). Individual pieces were sorted by size class categories ( 0 to $4 \mathrm{~cm}, 4.1$ to $9 \mathrm{~cm}, 9.1$ to $15 \mathrm{~cm}$, and greater than $15 \mathrm{~cm}$ ), counted, and weighed by size class. The overall shape was recorded as rounded, angular, or slab along with the presence of absence of cracks. Provenience data were also recorded. Although all burned rocks recovered during the excavations (roughly 90 pieces) were brought to the laboratory, only a sample of about 12 burned rocks from Feature 1 and a similar number from nonfeature contexts were selected for curation.

Historic artifacts such as glass fragments, metal pieces, and nails were also collected and bagged by provenience. These items were examined in the laboratory for identification marks that would link them to specific manufactures and time periods. The 11 historic items were not of significance and thus were not curated with the permission of THC.

The prehistoric cultural materials, notes, photographs, records and forms will be permanently curated at the Texas Archeological Research Laboratory (TARL). The slides and black and white photos were labeled according to TARL standards and where appropriate placed in acid free plastic sleeves for curation. 


\subsection{GEOMORPHIC RESULTS}

\subsection{Background}

The study area is located near the southern margin of Rolling Plains/Osage Plains section of the Central Lowlands Physiographic Province, an area noted for its low relief and occasional east-facing escarpments caused by resistant geologic strata that dip to the west (Fenneman 1938). The geologic strata in this zone are dominated by Pennsylvanian and Permian sedimentary rocks, particularly limestones, shales, and sandstones. In the study area, the Permian San Angelo formation is the primary geologic stratum exposed at the surface (Barnes 1974). This formation is noted for its fine-grained quartz sandstone (varies from red, gray, yellow, and brown in color), red or bluish green shales, and occasional conglomerates composed of dolomite and siliceous pebbles. From our own observations, it appears that a reddish shale unit is at or near the surface in our study area.

Capping the bedrock and have interest to archeological studies are the Late Quaternary sediments. Late Quaternary soillsediment studies in the Abilene area are surprisingly sparse. As suggested by Ferring (1990: 257) few archeological geology studies have been done in the Rolling Plains of Texas probably because of a fewer number of reservoir projects and because "thick late Holocene to Recent alluvium conceals archeology sites." In contrast, there are more studies in the Rolling Plains of southwestern Oklahoma, the western margin of the Gulf Coastal Plain near Dallas that, though in a different alluvial drainage, may provide some guidelines to assist understanding the geomorphology in the Abilene area.

The most obvious characteristic of the proxy alluvial studies is that the deposits are quite thick. In the Rolling Plains of Oklahoma, studies of alluvial sediments in multiple canyons indicate that the shallowest that 2000 B.P. dates can be attained, to use as an approximation between Archaic and Formative components, is approximately $2 \mathrm{~m}$ below the modem surface (Ferring 1990: 260). In some instances, 2000 year-old sediments are not encountered until $4 \mathrm{~m}$ below the modem surface. In and even more extreme example, approximately $220 \mathrm{~km}$ northwest of the Abilene area near the High Plains-Rolling Plains border, studies of sediments near the head of the Little Red River indicate over $7 \mathrm{~m}$ of sediments deposited in the last 2000 years (Baumgardner 1986: 23). Another example of thick Holocene deposits in the region are along the Upper Trinity River and it tributaries near the Dallas-Forth Worth area. Several stratigraphic columns in this area indicate that 2000-year old sediments are approximately 3 to $4 \mathrm{~m}$ below surface (Ferring 1990:262).

As a result of so many thick alluvial sequences being observed in the region, similarly thick sediments were expected along Noodle Creek. Our results indicate a soil 
sediment sequence that is much thinner than these regional examples, with weathered shale bedrock being encountered as shallow as $1.1 \mathrm{~m}$ below the surface on the T1 terrace. Though the results and interpretations will be discussed in more detail below, our initial conclusion is that the Noodle Creek alluvial sequence does not correlate well, at least based on depth below surface, with other regional analogs. Instead, it may be better to make comparisons based on the paleoenvironmental interpretations, such as alluviation and downcutting, than depth. These comparisons will be examined in the paleoenvironmentalinterpretations section of this report.

\subsection{Geomorphic Field Results}

Backhoe trench 6, located on the western side of CR 347 yielded artificial fill to a depth of about $70 \mathrm{cmbs}$ with recent historic material mixed in the fill. The unit below the artificial fill was a clay loam classified as a Bk horizon to a depth of $125 \mathrm{cmbs}$ (Abbott n.d.). A total of about $43 \mathrm{~m}^{3}$ of dirt was removed by backhoe trenching.

Investigations of the test units and backhoe trenches at 41JS102 resulted in the delineation of three major depositional packages that comprise two alluvial terraces of Noodle Creek (Figure 5-1). All of the prehistoric cultural materials observed on the site occur on the higher elevation $\mathrm{T} 1$ terrace, while the majority of the sediments on the lower elevation $\mathrm{TO}$ terrace appear to be relatively recent, possibly historic, in age. The flaked lithic materials and pieces of mussel shell recovered from the $\mathrm{T} 1$ terrace are primarily associated with what appears to be an unconformity between the two oldest depositional packages on the T1 terrace, though materials recovered from TUs 1 and 6 near BT 1 appeared to have some of the materials within the upper portions of the lowest depositional unit. The following section describes the specifics of these investigations and their implications for archeological materials observed on site.

The basal unit observed on the site was only observed in backhoe trench 1 (BT 1). It consists of a red (2.5YR 5/6, moist), massive clay loam (Unit I). This red clay loam exhibits common ( 5 percent), medium-sized masses of carbonate that may be have originated from groundwater instead of pedogenic processes. For these reasons, this unit is considered a $4 \mathrm{C}$ horizon. The most striking feature of these clay-rich sediments is their very red color that contrasts with the overlying deposits. Considering that the underlying Permian bedrock, the Clear Fork Group, is known for its red-colored sandstone and shale, it is likely that the clay-rich basal unit observed at 41JS102 consists of residual Permian shale. If it has not directly weathered in place, then the material is likely very near its source, possibly having been reworked by colluvial and/or alluvial processes. Given this interpretation, this unit is considered to be too old to yield non-intrusive archeological materials. 


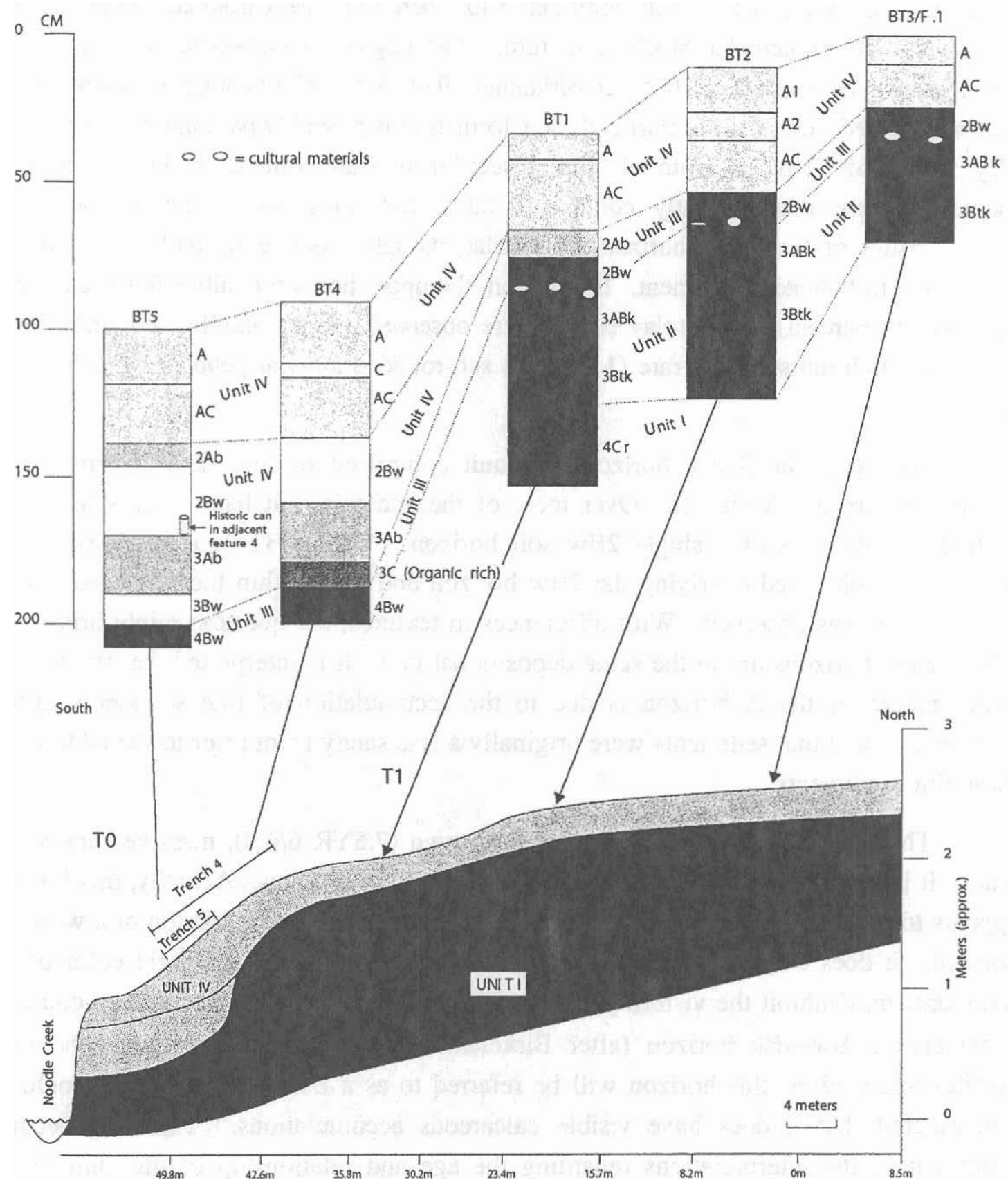

Figure 5-1. Generalized Stratigraphy Observed at 41] S102 
Overlying the red clay loam is another unit of clay loam (Unit II) that exhibits evidence of two soil horizons (3ABk and 3Btk). The lower 3Btk horizon is a brown (7.5YR $5 / 2$ moist) clay loam that exhibits common (5 to 7 percent), fine, carbonate filaments and a moderate, fine, subangular blocky structure. The degree of carbonate accumulation is considered to be Stage I+ to II (after Birkeland 1984: 358). Clay cutans are common (10 percent) on ped faces but are thin and their formation is probably partially due to the high clay content of the parent material. Fine insect burrows are common within this horizon, including those that currently contain termites, indicating some bioturbation. The characteristics of the 3ABk horizon are similar, though it is slightly darker (7.5YR 5/2, moist) due to humate enrichment. In addition, the upper horizon exhibits fewer carbonate filaments ( 3 percent) and no clay cutans were observed. It also exhibits common insect burrows. Both units exhibit rare (1 percent) sub-rounded alluvial pebbles up to $5 \mathrm{~mm}$ in diameter).

Overlying the $3 \mathrm{ABk}$ horizon is a unit comprised of fine sandy loam-to-loam textured sediments (Unit III). Over most of the site this unit has a fine sandy loam texture and consists of a single $2 \mathrm{Bw}$ soil horizon. Within $\mathrm{BT} 1$, an additional $2 \mathrm{Ab}$ horizon was observed overlying the $2 \mathrm{Bw}$ horizon and it is within the A horizon that a loam texture was observed. With differences in textures, the question might arise as to whether the horizons are in the same depositional unit. It is interpreted that the slightly siltier nature of the A horizon is due to the accumulation of fine sediments during pedogenesis and that sediments were originally a fine sandy loam prior to the addition of these finer sediments.

The 2Bw horizon typically is a light brown $(7.5 \mathrm{YR} 6 / 4, \mathrm{~d})$, massive, fine sandy loam. It has common insect burrows, including those of termites. Actually, this horizon appears to be at the cusp between being classified as a cambic Bw horizon or a weak $\mathrm{Bk}$ horizon. It does exhibit a few, fine, carbonate filaments, though the light color of the sediments may inhibit the visibility of these filaments. As a result the horizon could be considered a BW->BK horizon (after Birkeland 1984:11). For consistency between profiles and studies, this horizon will be referred to as a Bw horizon, but it should be remembered that it does have visible calcareous accumulations. This will become important in the interpretations regarding the age and relationship of this unit to the underlying deposits. The light brown sediments of Unit III are the lowest deposits that can be traced all of the way across the study area. On the $\mathrm{T} 1$ terrace these sediments are typically 10 to $20 \mathrm{~cm}$ thick and occur at approximately 50 to $60 \mathrm{~cm}$ below the surface. On the $\mathrm{TO}$ terrace the Unit III sediments thicken dramatically (over a meter thick in one point of BT 5) and extend beyond below the base of the backhoe trenches. 
The $2 \mathrm{Ab}$ horizon is a gray (7.5YR 5/1, moist) loam with very weak, fine granular structure. While the sediments do effervesce when tested with dilute hydrochloric acid, no visible carbonates were observed within the $2 \mathrm{Ab}$ horizon. As with virtually every unit or horizon observed on the site, insect burrows are common, though not so abundant as to blur major stratigraphic boundaries. The presence of this horizon in only a single backhoe trench is interpreted to simply be due to fortuitous preservation. Trench 1, where it is preserved, occurs just below the edge of a slight drop in elevation on the T1 surface. If this drop were due to erosion, like a strath cut by the adjacent stream, it would be expected that BT 1 would have strata missing (as compared to BT 2). Instead, it appears that BT 1 has an even more complete record of stratigraphy. As a result, the decrease in elevation between BTs 1 and 2 is considered to be an anomaly in the slope that does not reflect any impact on the stratigraphic record.

The uppermost deposits, Unit $\mathrm{N}$, consist of multiple individual strata all notable for their fine sandy loam structure and weak A horizon development. On the T1 terrace, these sediments typically consist of 23 to $50 \mathrm{~cm}$ of fine sandy loam and up to three incipient A horizons. The thinnest Unit $\mathrm{N}$ deposits occur at the northern margin of the site where only $23 \mathrm{~cm}$ of sediments occurred in the BT 3/Feature 1 vicinity (Figure 5-1). Distinguishing these horizons often proved difficult at the time of our study because moisture from recent snow was still present in the profile and made the boundaries less distinct. These boundaries were more distinct under the dry conditions observed during the initial investigations of the site (Abbott n.d.). Nevertheless, the horizons appear to represent multiple, relatively young, overbank depositional events on the T1 terrace.

The Unit IV sediments thicken considerably on the lower elevation T0 terrace (over $1 \mathrm{~m}$ thick) and display several more alluvial strata. For being adjacent to one another, the stratigraphy in BTs 4 and 5 vary more than expected, indicating that some of these strata may be small lenses of sediment as opposed to widely traceable stratigraphic layers. In particular an organic and clay rich deposit at the base of the Unit IV sediments was only observed in BT 4. The very dark gray (7.5Y R3/1, moist) color of this unit is due to an abundance of organics. Inspection of the unit suggests that this is from an organic and clay-rich slurry that resulted from overbank deposition as opposed pedogenic development. As a result, it is considered a geologic deposit instead of a pedogenic horizon. The other overlying strata often show weak A horizon development and/or weak to nonexistent subsurface pedogenesis ( $\mathrm{Bw}$ and $\mathrm{C}$ horizons). Based on their position on the $\mathrm{TO}$ terrace and weak pedogenic properties, these sediments were considered to be relatively recent throughout the field studies. This assessment was confirmed when a metal can was encountered $70 \mathrm{~cm}$ below the surface in TU 4, only $1 \mathrm{~m}$ south of the end of BT 5. A local, unidentified farmer who visited the site during testing 
provided further corroborating the interpretation of youthful surface sediments on both the T1 and TO terraces. He said that he had seen floods that inundated all of the land between Noodle Creek and the Brazos River, approximately $1 \mathrm{~km}$ to the north.

\subsection{Geomorphic Interpretations}

Interpretation of the nature and origins of Unit II and its $3 \mathrm{ABk}$ and $3 \mathrm{Btk}$ horizons is of particular importance to the understanding of the site, because most of the prehistoric cultural materials occur on the upper contact or within the upper few centimeters of the $3 \mathrm{ABk}$ horizon. First, the relationship to the underlying shale residuum affects the possibility of the Unit 11 sediments to yield in situ cultural materials. The texture of the Unit 11 sediments is somewhat similar to those observed in Unit I, though they lack the red colors. Color differences may be accounted for by pedogenic alteration, so then the question is whether the Unit I and II sediments actually have the same origin (i.e. residuum) and that the $\mathrm{ABk}$ and $\mathrm{Btk}$ horizons simply represent soil formation within the upper portions of the residuum. Our interpretation is that this is not the case. Both the 3Abk and 3Btk horizons exhibit rare sub-rounded pebbles within the fine-grained matrix, a property that suggests an alluvial origin. It cannot, however, entirely be ruled out that these pebbles were brought to the area by slopewash processes because the surrounding uplands are capped by gravels and other alluvium of the Quaternary Seymour formation. Our impression is that the Unit II sediments are overbank alluvium that is derived from reworking of clay-rich Permian bedrock from further up the drainage instead of residual sediments, but textural analyses might help clarify this issue.

The soil horizons within Unit II also have implications for the archeological materials on the site, particularly the $3 \mathrm{ABk}$ horizon upon which the cultural materials rest. An A horizon represents a stable surface that may have persisted for an extended period of time, anywhere from a hundred to a few thousand years. By it's very nature, the A horizon represents some stability because the humic material in the horizon results from plants living and dying on the surface of the soil. Thus, the cultural materials resting on this horizon may be from an occupation or multiple occupations during a period of semistability and increased plant cover.

The complication to this interpretation comes from the carbonate enrichment observed in the unit and the clay-rich nature of the sediments. Normally A horizons, both due to their surface position and relatively friable nature caused by insect and root activity, tend to be easy to erode. The 3ABk horizon at 41JS102 is not necessarily so vulnerable. Clay-rich soils tend to be more resistant to erosion than those comprised predominantly of silt or sand, due to the internal cohesion of the clays. In addition, carbonates such as those observed in the 3ABk horizon tend to increase the induration of 
the unit and make it more resistant to erosional processes. As a result, the question arises as to whether people occupying this surface put the cultural materials on the surface of the $3 \mathrm{ABk}$ horizon or whether the artifacts were concentrated there by deflation from erosion. Our interpretation is that the materials are in situ, an assessment that is partially based on the presence of carbonate filaments in the overlying unit.

Pedogenic carbonate accumulations in A horizons are almost always secondary accumulations that occur after the A horizon has been buried. This is due to the fact that organic acids that are present during humus formation discourage carbonate accumulation. After burial these acids are no longer being replaced and can be neutralized. The humates remain, but then may be overprinted by secondarily accumulating carbonate. This appears to be the case in the 3ABk horizon observed at 41JS102. The question then arises as to whether the carbonates were present in the $\mathrm{A}$ horizon before the cultural materials were deposited (which would favor the deposition through erosion model) or whether the carbonates accumulated after the cultural materials were buried (which would favor cultural occupation of the 3ABk surface). The simplest determinant would be the presences of carbonate accumulations directly on the cultural materials. The amount of carbonate accumulation that is observed in the $3 \mathrm{ABk}$ horizon is not very strong, however, and it is unlikely that any carbonate "pendants" could have developed on the underside of the cultural materials in such a situation. Instead, the overlying soil horizon (Unit III) provides the necessary information for basing an interpretation. Though often thin, the overlying unit exhibits a Bw horizon that appears to be transitioning to a $\mathrm{Bk}$ horizon (incipient $\mathrm{Bk}$ horizon). The degree of carbonate accumulation in that overlying horizon and that in the 3ABk horizon appears to be similar and is, thus, probably from the same soil-forming interval. As a result the carbonates in the $3 \mathrm{ABk}$ horizon appear to have developed after the cultural materials were buried as well. Thus, the carbonate induration of the $3 \mathrm{ABk}$ horizon was not present prior to the deposition of the cultural materials and it wouldn't have been as resistant to erosion as it is in its current state. Based on these properties and interpretations, it is concluded that the cultural materials resting on the surface of the $3 \mathrm{ABk}$ horizon are probably in situ.

What is not clear is how much of a time gap is present between the deposition of the sediments containing the $3 \mathrm{ABk}$ horizon and the sediments containing the $2 \mathrm{Bw}$ horizon. Because datable materials were not recovered from these units, the amount of time represented cannot be determined. It is possible that the $3 \mathrm{Abk}$ horizon represents a period of stability and soil formation that lasted for hundreds or even thousands of years. In such a scenario, it is possible that multiple cultural components are preserved on a single stratigraphic surface, resulting in a palimpsest. There is no evidence, however, 
that suggests that the opposite may not be true. It is possible that the cultural materials on this surface represent a single occupation and that the soil-forming interval was relatively short lived. If multiple components are observed on this surface, they do raise some question as to whether multiple occupations occurred on the same stable landform. Such interpretations are left to the archeologists and their interpretations of the recovered cultural materials.

Another item of interest was a large bovid bone recovered from the base of BT 4 toward the distal edge of the $\mathrm{TO}$ surface. This bone was identified during the initial testing on the site, but was left in the ground due to the complications regarding land ownership. This bone was rediscovered and recovered during our examinations of BT 4 . Our investigations indicate that this bone was approximately $5 \mathrm{~cm}$ into the Unit III BW horizon that extended to the base of the trench. During sampling, a few pieces of charcoal were encountered in the sediments approximately $5 \mathrm{~cm}$ south and at the same stratigraphic level as the bone. These charcoal fragments are not thought to be the result of any utilization of the bone, which was not burned, but the charcoal may be used to determine the age of the sediments associated with the bone. In field inspections, the bone did not have any obvious cut marks or other signs of human utilization and, thus, it may be natural in occurrence. Another note is that, though we tried to exactly match the re-excavated trench to what had been dug previously, a slight deviation was present. At the location of the bone, the trench was approximately $20 \mathrm{~cm}$ further east than the previous trench (as indicated by the thickness of disturbed sediments on the west wall). Due to this deviation, the backhoe trench encountered another large bone (or bones) in the east wall just east of the previously known bone. This new bone was slightly higher in the stratigraphic profile as it was associated with the organic and clay rich lowest stratum of the Unit IV sediments. It is unclear whether these two bones are from the same creature, but it would seem likely. Some uncertainty arises from the occur in slightly different stratigraphy. But it is possible that the lower bone may have sunk into the sediments during saturated conditions. This would be difficult, however, to prove. Unless the bone or bones display evidence of human utilization, or artifact associations though, this distinction may not be a critical to the archeological investigation.

\subsection{Regional Paleoenvironmental Considerations}

One of the big questions for Site 41JS102, especially considering the lack of datable materials, is whether the sediments can provide some chrono-stratigraphic controls through correlation with regional models. As was briefly mentioned in the introduction, the amount of sediments represented in most regional models (often $6 \mathrm{~m}$ or more of Holocene sediments) does not allow for easy correlation with the less than $2 \mathrm{~m}$ of sediments preserved on the Noodle Creek terraces. The first question that must be 
answered in this regard is why the sediments are so much thinner in the Noodle Creek drainage.

The most likely reason for the difference in sediment thickness between the Noodle Creek drainage and most other regional models probably has to do with bedrock controls and its position in the basin. Whereas many of the regional studies occur near the axis of the basin or in headwaters regions that are subject to high sediment contribution (e.g. the edge of the Llano Estacado escarpment), Noodle Creek is a relatively small tributary to the Brazos River and does not have any highly unstable sediment sources at its head. The most likely sources of sediment are from weathered bedrock along the course of the drainage and, based on our observations, the shale and limestone in this area are relatively, often ca. $1 \mathrm{~m}$ or less below present ground surface. It could very well be that the bedrock's proximity to the surface helped control the amount of stream cutting and, therefore, limited the amount of sediment in the system to create floodplain and terrace deposits. Today, the floodplain (T0) of Noodle Creek is only a few meters wide, which is a sharp contrast to the much wider floodplains of the Brazos and other rivers in the region. If shallow bedrock limitations were in effect in the past, they could truncate channel trenching and relieve the sediment load to the relatively thin sediment package preserved at site 41JS102. It is unclear, however, that the entire late Quaternary record of sedimentation and soil formation along this portion of Noodle Creek is represented by 1 to $2 \mathrm{~m}$ of sediment as opposed to the 6 to $8 \mathrm{~m}$ columns of sediment observed in other regional alluvial settings.

Despite the lack of direct stratigraphic comparisons, it may be possible that periods of stability and soil formation in other drainages might correlate with the soiltsediment record of Noodle Creek. In the absence of radiocarbon dates from Noodle Creek, any such correlations are speculative. However, if future research is conducted in the Noodle Creek vicinity, maybe datable materials will be recovered that will allow correlation between the observed soil/sedimentunits and other valleys in the region.

The regional soiltsediment records of Baumgardner (1986), Boyd and Tomka (1997), Ferring (1990), Hall (1978, 1982), Holliday (1997), and Hughes (1978) provide the following most common trends. Sedimentation appears to have been high in regional drainages between approximately 4000 and 2000 B.P. Large amounts of valley fill were deposited during this time. More stable conditions appear to have existed between approximately 2000 and 1000 B.P. that resulted in soil development. In southwestern Oklahoma, paleosols of this age are often referred to as the Caddo soil. After ca. 1000 B.P. it appears instability was again the norm and valley bottom deposition resumed, burying the previous soil. In some locales, stability was again achieved around 600 to 
400 B.P. and another soil developed (sometimes referred to as the Delaware Creek soil). This paleosol, however, does not appear to be as geographically widespread. A final sedimentation and soil formation event typically occurred later though the exact timing is not clear. This final soil/sediment package is typically considered the modern soil.

It is possible that the soil/sediment units in the Noodle Creek terraces represent a compressed version of the soil/sediment units observed in regional chronologies. Without datable materials this correlation cannot definitively be made but, instead, is made as a suggestion to possibly guide future research. Considering the strength of $\mathrm{A}$ horizon development in the $3 \mathrm{ABk}$ horizon, the clay and carbonate enrichment in the 3Btk horizon, and the position of these units in the profile, it is tentatively suggested that they may correlate to the ca. 2000 to 1000 B.P. Caddo soil. Likewise the weaker $2 \mathrm{Ab}$ and $2 \mathrm{Bw}$ horizons on the $\mathrm{T} 1$ terrace may correlate to the ca. 600 to 400 B.P. Delaware soil. That would mean that the upper ca. 30 to $50 \mathrm{~cm}$ of sediments at the site was all deposited within the past ca. 400 years. This is plausible considering the weak soil formation within these sediments. It is hoped that future research in the area will be able to recover datable materials to test these speculative correlations. 


\subsection{ARCHEOLOGICAL RESULTS}

The archeological investigations included the hand excavation of $6.75 \mathrm{~m}^{3}$ from eight 1 by $1 \mathrm{~m}$ test units. These excavations detected buried prehistoric cultural remains almost exclusively in the $\mathrm{T} 1$ terrace that extends over the northern two-thirds of the northeastern quadrant of the development zone. The lower $\mathrm{T} 0$ terrace immediately north of Noodle Creek is quite limited in aerial extent and appears to contain very recent alluvial deposits with scattered historic artifacts to a depth of at least $70 \mathrm{cmbs}$ and possibly to a depth of $140 \mathrm{cmbs}$. Only a single piece of lithic debitage was recovered from the $1.5-\mathrm{m}^{3}$ excavations in TU 4 in the lower $\mathrm{T} 0$ terrace deposits. No cultural materials were detected in BT 6 deposits that appeared to be mostly modern fill in the northwestern sector of the development.

The horizontal extent of site 41JS102 is unknown. The prehistoric cultural remains in the present study occur north of Noodle Creek, west of CR 347, and are confined to a ca. $8 \mathrm{~m}$ wide by $40 \mathrm{~m}$ long development zone across the T1 terrace (Figure 4-1). Because only the proposed, narrow TXDOT development zone was investigated for cultural remains the horizontal boundaries of 41JS102 have not been determined. The excavation results are discussed by alluvial terrace beginning with the more extensive T1 deposits.

\subsection{Cultural Materials from the T1 Terrace}

The $5.25 \mathrm{~m}^{3}$ of matrix hand-excavated from TUs 1 though 3 and 5 through 8 were derived from areas adjacent to BTs 1 through 3 . All these units penetrated the T1 deposits (Figure 4-1). The seven test units yielded a total of 872 pieces of cultural material, including 750 pieces of lithic debitage, 13 edge modified flakes, three stone tools, five cores, 90 burned rocks, and 11 historic items (Table 6-1). Also found were six bone fragments, 16 pieces of mussel shell, and 74 pieces of burned rock. These prehistoric cultural materials were vertically distributed within the $\mathrm{T} 1$ deposits in such a way as to indicate the presence of at least one well-defined, buried, prehistoric component separate from the limited and scattered historic materials that were buried just beneath the surface (Figures 6-1 and 6-2). 


\section{Table 6-1. Distribution of Artifacts by Test Unit and Depth Grouped by Terrace Placement at 41JS102}

\begin{tabular}{|c|c|c|c|c|c|c|c|c|c|}
\hline $\begin{array}{c}\text { Unit } \\
(1 \times 1 \text { m })\end{array}$ & Level & $\begin{array}{c}\text { Depth } \\
\text { (cmbs) }\end{array}$ & $\begin{array}{c}\text { Lithic } \\
\text { Debitage }\end{array}$ & $\begin{array}{c}\text { Bone } \\
\text { Fragments }\end{array}$ & $\begin{array}{c}\text { Shell } \\
\text { Fragments }\end{array}$ & $\begin{array}{c}\text { Burned } \\
\text { Rocks }\end{array}$ & $\begin{array}{l}\text { Stone } \\
\text { Tools }\end{array}$ & $\begin{array}{l}\text { Historic } \\
\text { Artifacts }\end{array}$ & Other \\
\hline \multicolumn{10}{|c|}{ Proximal T1 near BT 1} \\
\hline \multirow[t]{10}{*}{ Unit 1} & 1 & $0-10$ & & & & & & & \\
\hline & 2 & $10-20$ & 1 & & & & & $\begin{array}{c}1 \text { Bottle } \\
\text { cap }\end{array}$ & \\
\hline & 3 & $20-30$ & & & & & & & \\
\hline & 4 & $30-40$ & 1 & & & & & & \\
\hline & 5 & $40-50$ & & & & & & & \\
\hline & 6 & $50-60$ & & & & & & & \\
\hline & 7 & $60-70$ & 1 & & & & & & \\
\hline & 8 & $70-80$ & 21 & 1 & & & 1 Biface & & \\
\hline & 9 & $80-90$ & 58 & & & 19 & $\begin{array}{l}1 \text { Core, } \\
1 \mathrm{EMF}^{2}\end{array}$ & & \\
\hline & 10 & $90-100$ & 2 & & & & 1 Core & & \\
\hline Sub Total & & & 84 & 1 & 0 & 19 & 4 & 1 & $\mathbf{0}$ \\
\hline \multirow[t]{10}{*}{ Unit 6} & 1 & $0-10$ & & & & & & & \\
\hline & 2 & $10-20$ & & 2 & & & & & \\
\hline & 3 & $20-30$ & & 1 & & & & & \\
\hline & 4 & $30-40$ & & & & & & & \\
\hline & 5 & $40-50$ & 1 & & & & & & \\
\hline & 6 & $50-60$ & & & & & & & \\
\hline & 7 & $60-70$ & & & & & & & \\
\hline & 8 & $70-80$ & 9 & & 1 & 2 & & & \\
\hline & 9 & $80-90$ & 28 & & 1 & 14 & $1 \mathrm{EMF}$ & & \\
\hline & 10 & $90-100$ & 4 & & & & & & \\
\hline Sub Total & & & 42 & 3 & 2 & 16 & 1 & 0 & 0 \\
\hline \multicolumn{10}{|c|}{ Medial T1 near BT 2} \\
\hline \multirow[t]{8}{*}{ Unit 2} & 1 & $0-10$ & 4 & & & & $1 \mathrm{EMF}$ & $\begin{array}{c}3 \text { glass } 1 \\
\text { metal }\end{array}$ & \\
\hline & 2 & $10-20$ & & & & & & & \\
\hline & 3 & $20-30$ & & & & & & & \\
\hline & 4 & $30-40$ & 1 & & & & & & \\
\hline & 5 & $40-50$ & 60 & & & & $1 \mathrm{EMF}$ & & \\
\hline & 6 & $50-60$ & 102 & & & & & & \\
\hline & 7 & $60-70$ & 11 & & & & & & \\
\hline & 9 & $80-90$ & 1 & & & & & & \\
\hline Sub Total & & & 179 & 0 & 0 & $\mathbf{0}$ & 2 & 4 & 0 \\
\hline
\end{tabular}


Table 6-1. (Continued)

\begin{tabular}{|c|c|c|c|c|c|c|c|c|c|}
\hline $\begin{array}{c}\text { Unit } \\
(\mathbf{1} \times 1 \text { m) } \\
\end{array}$ & Level & $\begin{array}{c}\text { Depth } \\
\text { (cmbs) }\end{array}$ & $\begin{array}{c}\text { Lithic } \\
\text { Debitage } \\
\end{array}$ & \begin{tabular}{|c|} 
Bone \\
Fragments
\end{tabular} & $\begin{array}{c}\text { Shell } \\
\text { Fragments }\end{array}$ & $\begin{array}{c}\text { Burned } \\
\text { Rocks }\end{array}$ & $\begin{array}{l}\text { Stone } \\
\text { Tools } \\
\end{array}$ & $\begin{array}{c}\text { Historic } \\
\text { Artifacts }\end{array}$ & Other \\
\hline \multicolumn{10}{|c|}{ Medial T1 near BT 2 - (continued) } \\
\hline \multirow[t]{7}{*}{ Unit 5} & 1 & $0-10$ & 1 & & & & & 2 glass 2 & \\
\hline & 2 & $10-20$ & & 1 & & & & & \\
\hline & 3 & $20-30$ & & & & & & & \\
\hline & 4 & $30-40$ & & & & & & & \\
\hline & 5 & $40-50$ & 90 & & 1 & & 2 EMF & & \\
\hline & 6 & $50-60$ & 31 & & & & $1 \mathrm{EMF}$ & & \\
\hline & 7 & $60-70$ & 1 & & & & & & \\
\hline Sub Total & & & 123 & 1 & 1 & $\mathbf{0}$ & 3 & 4 & $\mathbf{0}$ \\
\hline \multicolumn{10}{|c|}{ Distal T1 near BT 3} \\
\hline \multirow[t]{7}{*}{ Unit 3} & 1 & $0-10$ & & & & & & & \\
\hline & 2 & $10-20$ & & & & & & & \\
\hline & 3 & $20-30$ & 4 & & & 1 & & & \\
\hline & 4 & $30-40$ & 76 & & & 19 & $\begin{array}{l}1 \text { core, } \\
1 \text { EMF }\end{array}$ & & charcoal \\
\hline & 5 & $40-50$ & 18 & & & 6 & $1 \mathrm{EMF}$ & & \\
\hline & 6 & $50-60$ & & & & & & & \\
\hline & 7 & $60-70$ & & & & & & & \\
\hline Sub Total & & & 98 & $\mathbf{0}$ & $\mathbf{0}$ & 26 & 3 & $\mathbf{0}$ & \\
\hline \multirow[t]{7}{*}{ Unit 7} & 1 & $0-10$ & & & & & & & \\
\hline & 2 & $10-20$ & 1 & & & 4 & & 2 metal & \\
\hline & 3 & $20-30$ & 4 & & & & & & \\
\hline & 4 & $30-40$ & 108 & & 1 & 9 & $\begin{array}{l}1 \text { core, } \\
2 \mathrm{EMF}\end{array}$ & & \\
\hline & 5 & $40-50$ & 21 & & & & 1 core & & \\
\hline & 6 & $50-60$ & & & & & & & \\
\hline & 7 & $60-70$ & & & & & & & \\
\hline Sub Total & & & 134 & 0 & 1 & 13 & 4 & 2 & 0 \\
\hline \multirow[t]{5}{*}{ Unit 8} & 1 & $0-10$ & & & & & & & \\
\hline & 2 & $10-20$ & 7 & 1 & & 3 & & & \\
\hline & 3 & $20-30$ & 2 & & 1 & 3 & 1EMF & & \\
\hline & 4 & $30-40$ & 53 & & 11 & 6 & $\begin{array}{c}\text { 1Zephyr } \\
\text { point, } \\
1 \mathrm{EMF}\end{array}$ & & \\
\hline & 5 & $40-50$ & 9 & & & 4 & & & \\
\hline \begin{tabular}{|l|} 
Sub Total \\
\end{tabular} & & & 90 & 1 & 12 & 16 & 3 & 0 & 0 \\
\hline
\end{tabular}


Table 6-1. (Continued)

\begin{tabular}{|c|c|c|c|c|c|c|c|c|c|}
\hline $\begin{array}{c}\text { Unit } \\
(1 \times 1 \mathrm{~m}) \\
\end{array}$ & Level & $\begin{array}{c}\text { Depth } \\
\text { (cmbs)' }\end{array}$ & $\begin{array}{c}\text { Lithic } \\
\text { Debitage }\end{array}$ & $\begin{array}{c}\text { Bone } \\
\text { Fragments }\end{array}$ & $\begin{array}{c}\text { Shell } \\
\text { Fragments }\end{array}$ & $\begin{array}{c}\text { Burned } \\
\text { Rocks }\end{array}$ & $\begin{array}{l}\text { Stone } \\
\text { Tools } \\
\end{array}$ & $\begin{array}{l}\text { Historic } \\
\text { Artifacts } \\
\end{array}$ & Other \\
\hline \multicolumn{10}{|c|}{ Distal T0 near BT 5} \\
\hline \multirow[t]{15}{*}{ Unit 4} & 1 & $0-10$ & & & & & & $\begin{array}{c}\text { I glass } \\
\text { piece }\end{array}$ & \\
\hline & 2 & $10-20$ & 1 & & 1 & & & & \\
\hline & 3 & $20-30$ & & 2 & & & & barbwire & \\
\hline & 4 & $30-40$ & & & & & & & \\
\hline & 5 & $40-50$ & & & & & & & \\
\hline & 6 & $50-60$ & & & & & & & \\
\hline & 7 & $60-70$ & & & & & & 1 metal can & \\
\hline & 8 & $70-80$ & & & & & & & \\
\hline & 9 & $80-90$ & & & & & & & \\
\hline & 10 & $90-100$ & & & & & & & \\
\hline & 11 & $100-110$ & & & & & & & \\
\hline & 12 & $110-120$ & & & & & & & \\
\hline & 13 & $120-130$ & & & & & & & \\
\hline & 14 & $130-140$ & & 2 & & & & & \\
\hline & 15 & $140-150$ & & & & & & & \\
\hline Sub Total & & & 1 & 4 & 1 & 0 & $\mathbf{0}$ & 3 & $\mathbf{0}$ \\
\hline
\end{tabular}

1.cmbs = centimeters below surface 2. EMF =Edge modified flake 

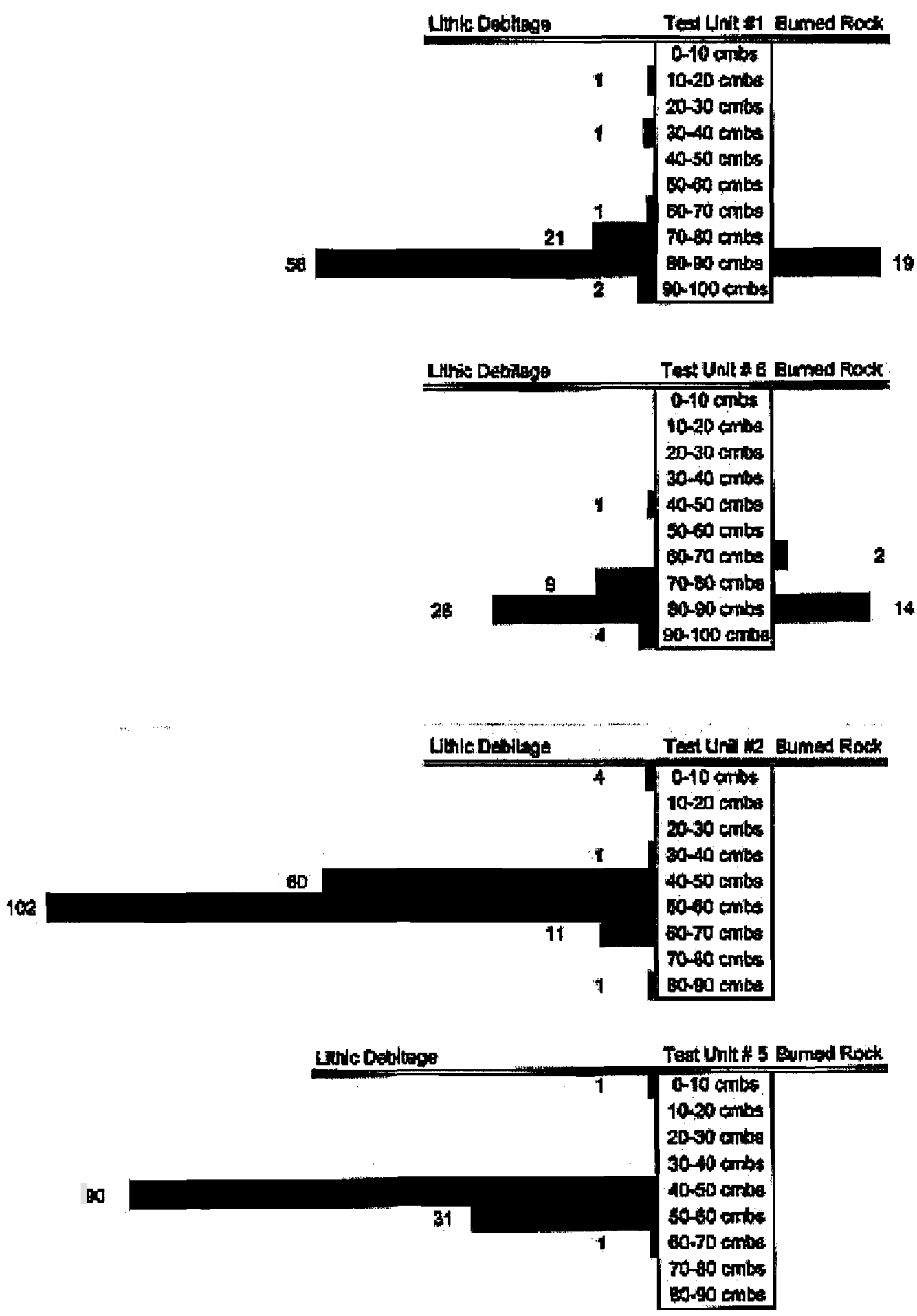

Figure 6-1. Lithic Debitage and Burned Rock Count Distribution for Distal T 1 Setting (Units 3,7, and 8) at 41J S102 


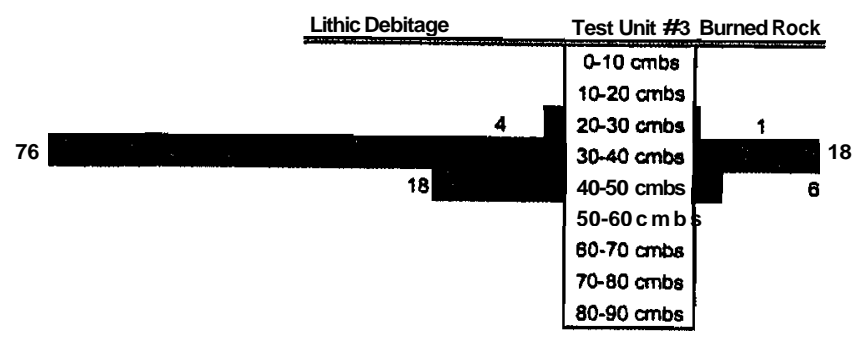

108
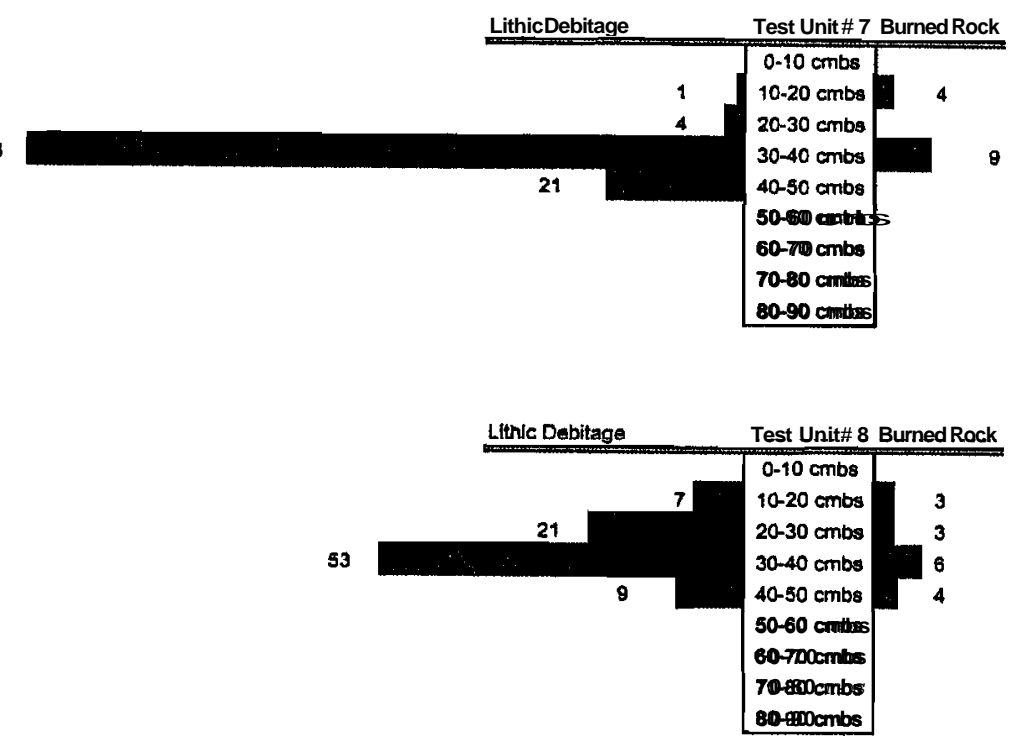

Figure 6-2. Lithic Debitage and Burned Rock Count Distribution for Proximal T1 (Units 1 and 6) and Medial T1 (Units 2 and 5) Settings at 41J S102 
The prehistoric component encountered in the $\mathrm{T} 1$ deposits varied considerably in depth from the north to south end of the development and correlates to the distances from the terrace edge. At the distal terrace (northern end) this component was between 35 and $50 \mathrm{cmbs}$ in TUs 3, 7, and 8, whereas at the proximal end (southern end) the component was between 75 and $90 \mathrm{cmbs}$ in TUs 1 and 6 (Figure 4-1). This 10 to $15 \mathrm{~cm}$ thick prehistoric component yielded 742 pieces of lithic debitage, 86 burned rocks, 16 fragments of fresh water mussel shell, 12 edge modified flakes, five cores, four formal stone tools including two from trench backdirt, and one possible feature (Feature 1) from $5.25 \mathrm{~m}^{3}$ excavated area.

\subsubsection{Features}

TxDOT personnel originally discovered Feature 1 during backhoe trenching (BTs $3 a$ and $3 b$ ) on September 19, 2001. Upon TxDOTs unexpected early departure from the site this feature was covered with black plastic and dirt. Subsequently, on December 7, 2001 TRC archeologists excavated a northern section of Feature 1 from TU 8 (Figures 63 through 6-5). Feature 1 appeared as a concentration of mostly flecks and chunks of charcoal associated with some decomposed wood chunks in an amorphous, ill-defined area on the southern side of TU 8. The charcoal concentration was not well-defined and absolute boundaries were not detected. The stained sediments extend beyond the south wall of TU 8 and therefore, the entire horizontal extent and overall shape is unknown. The exposed charcoal concentration was roughly 20 by $40 \mathrm{~cm}$ in diameter. The charcoal was first observed at ca. $33 \mathrm{cmbs}$ and appeared to continue to at least $45 \mathrm{cmbs}$, for a depth of $12 \mathrm{~cm}$, but the precise bottom was not encountered. Charcoal chunks appeared to continue into the floor of the unit at $45 \mathrm{cmbs}$. About three liters of dark stained and charcoal rich matrix was collected from this concentration. No formal basin, defined oxidation layer, or ash was observed. In at least one spot within the stain, the charcoal appeared to form an 8 to $10 \mathrm{~cm}$ long line about $1.5 \mathrm{~cm}$ in diameter, which was thought to be a burned stick that lay horizontal near a small burned rock within the charcoal concentration (Figure 4-1). The charcoal concentration appeared to be within a 10 to 15 $\mathrm{cm}$ thick zone of associated cultural material.

A total of $9.4 \mathrm{~g}$ of charcoal was recovered from fine screening the three liters of matrix collected from Feature 1. A single chunk of charcoal $(0.1 \mathrm{~g})$ was selected from the matrix sample collected from between 30 to $40 \mathrm{cmbs}$ and submitted to Beta Analytic for radiocarbon dating. That charcoal chunk yielded a $\delta^{13} \mathrm{C}$ corrected $(-26.3 \% 0)$ AMS date of $400+/-40$ B.P. (Beta-162672; Appendix A). Two burned rocks were north of the charcoal staining at depths of 34 and $35 \mathrm{cmbs}$ (Figures 6-3 and 6-5). A large $10 \mathrm{~cm}$ diameter flake was along the outside western edge at a depth of $34 \mathrm{cmbs}$ and a Zephyr point was $5 \mathrm{~cm}$ east of the stain at $39 \mathrm{cmbs}$ in TU 8 . 

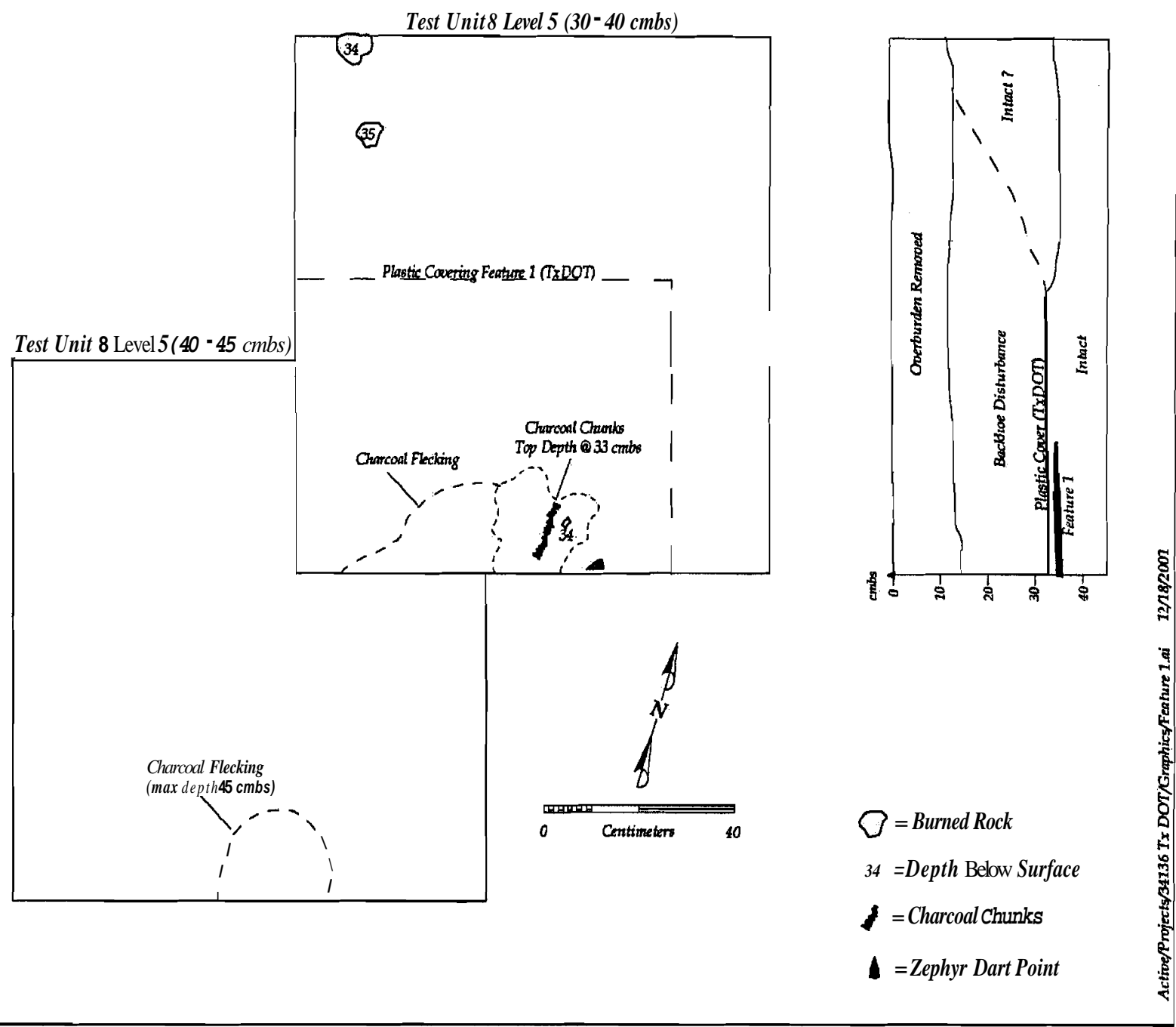

Figure 6-3. Plan Map and Profile of Feature 1 in Test Unit 8, 41JS102 


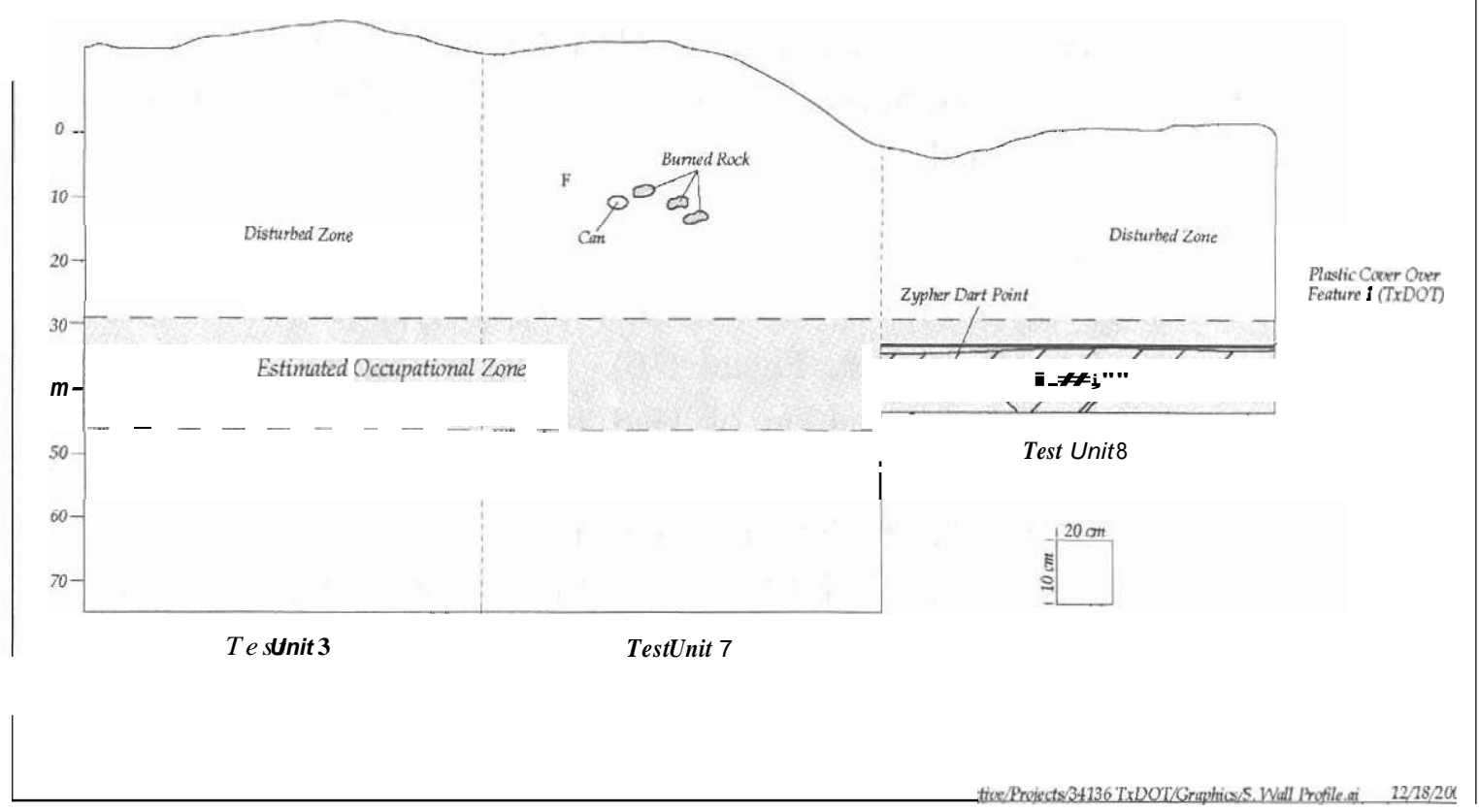

Figure 6-4. Profile of Test Units 3, 7, and 8 Indicating the Buried Cultural Component

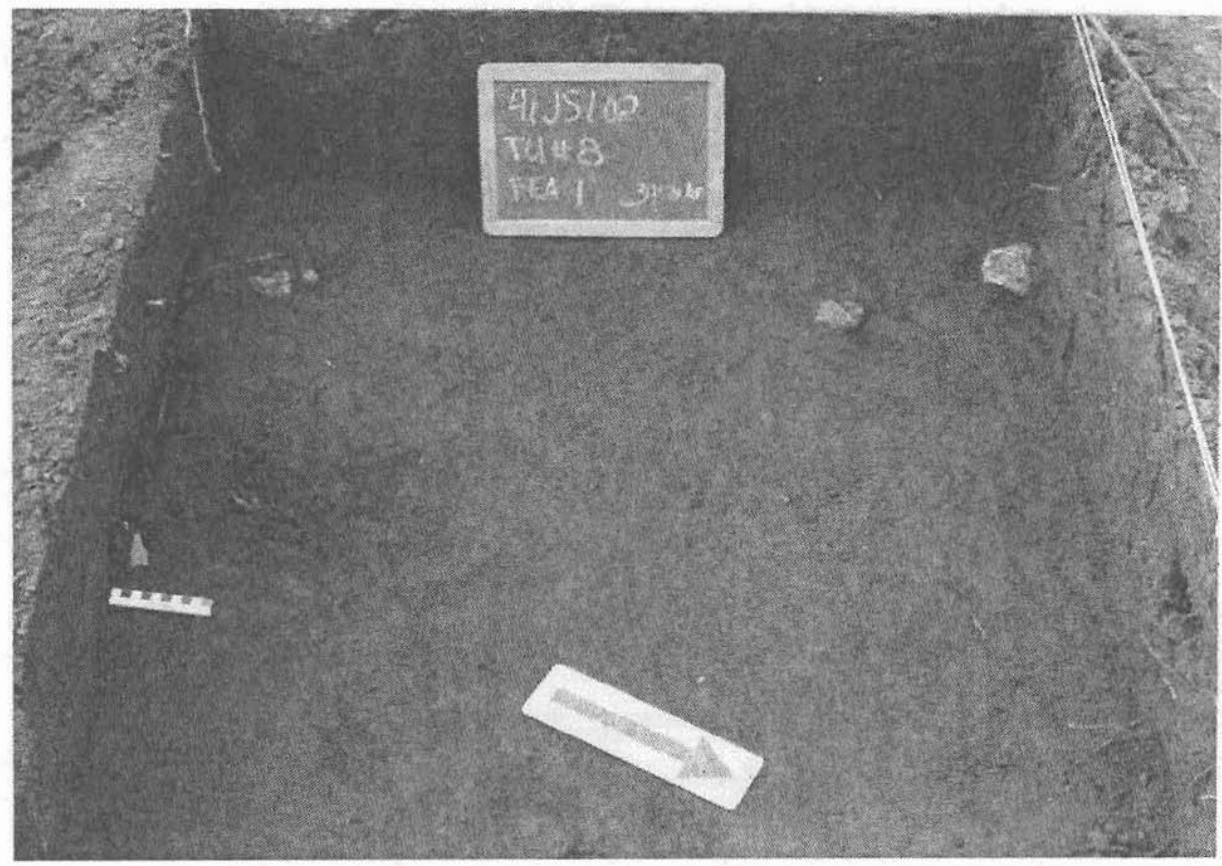

Figure 6-5. Plan View of Feature 1 in Test Unit 8,41Js102, Showing Zephyr Point in Situ 


\subsubsection{Material Assemblage}

This section describes the artifact assemblage for the T1 terrace. It is organized by chipped stone tools (points, bifaces, cores, and edge modified flakes) lithic debitage, burned rocks, mussel shell, and bones.

\section{Points ( $\mathbf{N}=\mathbf{1})$}

The dart point (\#028-5) was identified as a Zephyr type (Prewitt n.d., 1982:96; personally identified by E. Prewitt, Figure 6-6). The provisional Zephyr type was originally part of the broad definition of Darl prior to about 1976 when Prewitt recognized that three separate points types representing different periods of time had been lumped into the Darl type. In the Rogers Spring report Prewitt (n.d.) described three separate points referred to as Darl Mahomet, Darl Hoxie, and Darl Zephyr. He distinguishes the Darl Zephyr as having a blade that varies in shape, with lateral edges that are always more steeply beveled than the Mahomet specimens, but usually less so than the Hoxie variety. The flakes scars on the bevel are often parallel and result in evenly serrated lateral edges. The scars are not as fine as the oblique scars often exhibited by the Mahomet variety. The shoulders are squared. Specimens that have been resharpened often exhibit short barlike projections at the shoulder. The stems expand moderately and the bases are gently concave. The lateral edges are usually alternately beveled, but rarely exhibit smoothing or grinding.

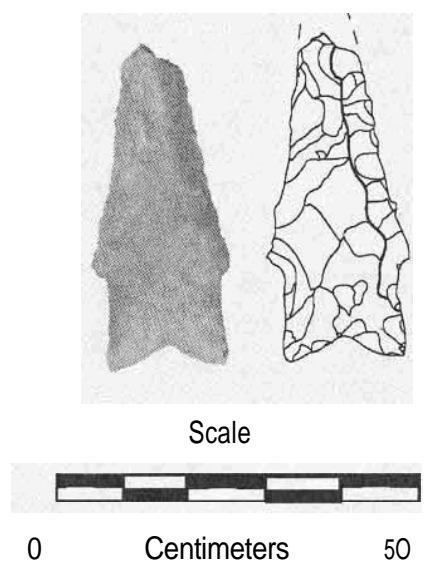

Figure 6-6. The Zephyr Dart Point (\#028-5) from 41JS102 
Specimen \#028-5 has straight lateral edges that are steeply beveled on the right side of each face creating a diamond shaped cross section. The shoulders are prominent but unbarbed. The stem is well formed with straight lateral edges that expand every so slightly to relatively pointed basal tangs. The base is concave but angular like a fish tail. Both the base and stem are ground. The very distal tip of the Zephyr point is missing and appears to have broken from use (Figure 6-6). This point measures $44 \mathrm{~mm}$ long, $20 \mathrm{~mm}$ wide, and $6.5 \mathrm{~mm}$ thick just above the shoulders. The stem width or base width measures $18 \mathrm{~mm}$ wide, and the stem measures $13 \mathrm{~mm}$ long. The point weighs $5.8 \mathrm{~g}$. It was manufactured from a light gray, very fine-grained high quality chert. Zephyr points are believed to have been made during the Late Archaic period, although the age and cultural affiliation of this type are poorly known. It's association with a 400-year-old charcoal date indicates that either the dart point had been scavengered by later peoples and is not representative of the other cultural remains, or the radiocarbon date is on a burned piece of wood or root dating later than the occupation.

\section{Bifaces ( $\mathbf{N}=\mathbf{3}$ )}

Three bifaces were recovered from the $\mathrm{T} 1$ terrace. One is a proximal biface fragment (\#023-1) recovered from the backdirt of BT 1 during the digging and is assumed to have come from this component. About six pieces of debitage from TUs 1 and 6 appear similar to the color and material type to this biface. This proximal fragment appears to have been broken during use (Figure 6-7). This biface is well formed with completely worked faces. A tiny spot of lighter colored cortex is still present on one face. This tool represents a late stage, ovate biface without evidence of lateral edge grinding. The broken specimen measures $50 \mathrm{~mm}$ long, $40 \mathrm{~mm}$ wide, $6 \mathrm{~mm}$ thick, and weighs $16.9 \mathrm{~g}$. It was made from a high quality, fine-grained gray chert with scattered, tiny, white inclusions.

A second biface (\#030-1) was also recovered from the backdirt of BT 2. At least a dozen pieces of lithic debitage from the component in TUs 2 and 5 visually appear to be very similar in material type and color to this biface. This proximal biface fragment may have been broken during manufacturing. A flat, ovate platform that measures $13.8 \mathrm{~mm}$ long is still present on the very proximal end and exhibits a very small area of cortex. Both faces exhibit multiple flake scars, but one face has a large scar that appears to have come from the distal end and carried diagonally all the way across the face and removed nearly all of one lateral edge. The opposite lateral edge exhibits some edge trimming that may indicate reuse after the breakage occurred (Figure 6-7). This broken biface measures $44.3 \mathrm{~mm}$ long, $39.5 \mathrm{~mm}$ wide, $10.0 \mathrm{~mm}$ thick, and weighs $15.2 \mathrm{~g}$. It was made from a high quality, fine-grained beige to cream colored chert. 
The crude biface (\#066-2) is made of a fine-grained chert that appears to have been heat treated, as evident from a very light ting of red and a very glossy finish. The biface appears to have broken during manufacture and represents an early stage in the reduction sequence (Figure 6-7). The few flake scars are random, the edges are very sinuous, and there is no edge trimming. A large, deep flake scar is present on one face and this may be the reason for its discard. It measures $60 \mathrm{~mm}$ long, by $40 \mathrm{~mm}$ wide, is 20 $\mathrm{mm}$ thick and weighs $42.1 \mathrm{~g}$.

\section{Cores $(\mathbf{N}=\mathbf{5})$}

Five cores (\#035-2, M36-2, \#043-2, \#063-2, and \#064-2) were recovered from test excavations across the T1 terrace. All cores consist of water-worn, high-grade chert and quartzite cobbles with multiple, large flake removals. Four are nodular in overall morphology and one is a water-worn piece of tabular chert. Cortex is present on all five cores, ranging from 10 to 60 percent of the total surface. None of the cores exhibits any clear evidence of thermal alteration. Each core is discussed in detail below.

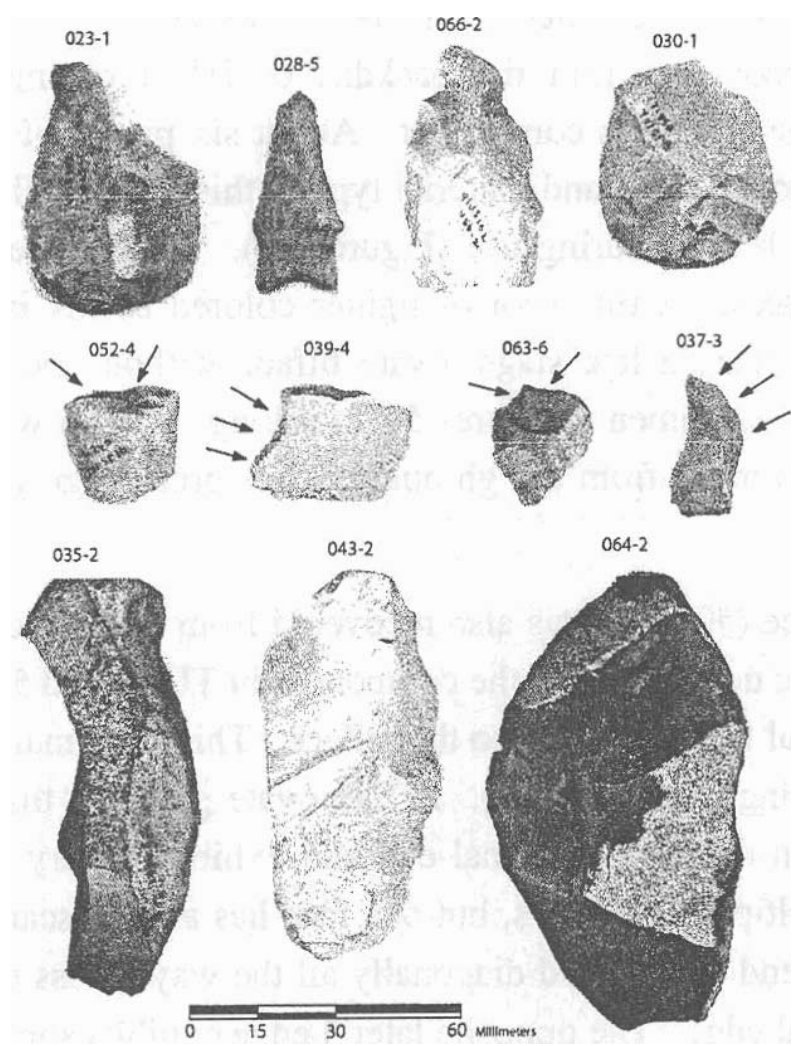

Figure 6-7. Selected Artifacts from 41JS102 
Specimen \#035-2 is a thin, oblong, tested pebble of a fine-grained, light brown chert (Figure 6-7). Approximately 60 percent of the surface of this core is covered with water-worn cortex. This core exhibits four large flake scars and platform crushing along a limited portion of one edge. This core measures $9.7 \mathrm{~cm}$ long by $3.3 \mathrm{~cm}$ wide by $2.8 \mathrm{~cm}$ thick, and weighs $116.7 \mathrm{~g}$.

Specimen \#036-2 consists of an extensively flaked nodule of fine-grained, fossiliferous, cream-colored chert. This core is a roughly pyramid-shaped, multidirectional core with one small patch of remaining cortex that covers about 10 percent of its surface. The core has 14 flake removals in addition to extensive platform preparation crushing along one-half of the primary platform surface. This core measures $5.6 \mathrm{~cm}$ long, $3.3 \mathrm{~cm}$ wide, and $3.3 \mathrm{~cm}$ thick, and weighs $65.9 \mathrm{~g}$. This core is not exhausted.

Specimen \#043-2 consists of a tabular piece of fine-grained, light brown chert that appears to represent an abandoned biface preform (Figure 6-7). One edge has been worked into a sinuous, bifacial edge whereas the opposite face is almost completely covered in cortex. Six large flakes have been removed from one face and 17 have been removed from the opposite face. Between 10 and 15 percent of each face, as well as most of one edge, remains covered in cortex. The core is roughly ovate in overall shape. The face of the core that exhibits more extensive flaking has one particularly large flake scar that covers more than one-quarter of the face. The percussion bulb of this flake scar cuts very deeply into the core and significantly reduces the width-to-thickness ratio of the core for further reduction and offsets the symmetry of the core. This flake scar likely rendered this core unsuitable for biface manufacture, resulting in its abandonment. This core measures $8.4 \mathrm{~cm}$ long by $4.0 \mathrm{~cm}$ wide by $1.7 \mathrm{~cm}$ thick, and weighs $67.3 \mathrm{~g}$.

Specimen \#063-2 is little more than a large, primary, core-reduction flake with a few flake removals from its ventral, non-cortical surface. The raw material is a finegrained quartzite with numerous large mineral inclusions. Approximately 40 percent of this core is covered with water-worn pebble cortex. Only seven flake removals are evident on this core, at least two of which are present on the dorsal surface of the flake. These flakes would have been removed from a larger core before this flake was struck. The ventral surface of this specimen exhibits three unidirectional flake scars and a minor degree of platform preparation along one edge. This core measures $7.5 \mathrm{~cm}$ in long by 3.3 $\mathrm{cm}$ wide by $4.9 \mathrm{~cm}$ thick, and weighs $108.4 \mathrm{~g}$.

The final core \#064-2 is a bifacially flaked, tested cobble of a fine-grained, light gray quartzite (Figure 6-7). This core resembles a chopper in overall morphology (i.e., it has one sharp edge and one "backed," cortical edge), but it exhibits no signs of use as a 
tool. The core is roughly triangular in cross-section - bifacial flake removal forms a gently curved, sharp edge along two-thirds of the core's edge while the remaining onethird is covered in cortex. This core has a total of 16 flake removals, seven from one face and nine from the other. Flake removals are multidirectional, though most of them originate from opposing ends (i.e., bidirectionally). Although this core is little more than a tested cobble, its size and the pattern of flake removals suggest that it may have been intended for biface manufacture. However, the large mineral inclusions and the presence of one flake scar that terminates in a deep step fracture probably presented the reason why the core was not reduced any further. This core measures $99.5 \mathrm{~cm}$ long by $56.4 \mathrm{~cm}$ wide by $33.2 \mathrm{~cm}$ thick, and weighs $198.3 \mathrm{~g}$

The small core assemblage offers a few insights into the technological practices of the inhabitants. Only one of the five cores appears to have been extensively reduced for flakes, which suggests that raw material was not, as a rule, particularly scarce. It also implies that unifacial flake tool technology was employed at this site. One core appears to be a biface preform that was abandoned in an early stage of manufacture, reinforcing the evidence for biface production clearly represented in the debitage assemblage (see below). The other three cores are little more than tested cobbles with a limited number of flake scars. All of the cores consist of cryptocrystalline cherts and fine-grained quartzites, indicating a clear selection for high-grade raw materials. In addition, all cores retain some cortex (ranging from 10 to 60 percent of their surface areas), suggesting that raw materials were procured from relatively local stream beds or high terraces.

\section{Edge Modified Flakes ( $N=12$ )}

The 12 edge modified flakes were all high quality cherts with all but one, an intentional graver, classified as expedited tools (Figure 6-7). They are flake or flake fragments selected and used without intentional retouch to prepare an edge for a desired task. Fifty-eight percent are complete flakes, 25 percent are proximal pieces, and 17 percent are medial sections (Table 6-2). Eighty-three percent have only one edge that was used and those edges vary in shape from convex, to straight, to concave. Fifty-eight percent exhibit tiny, parallel flake scars along the used edge, whereas the other pieces show irregular scaring. The identification of informal tools indicates that flakes were selected from the knapping debris and used for various cutting and scraping tasks. 


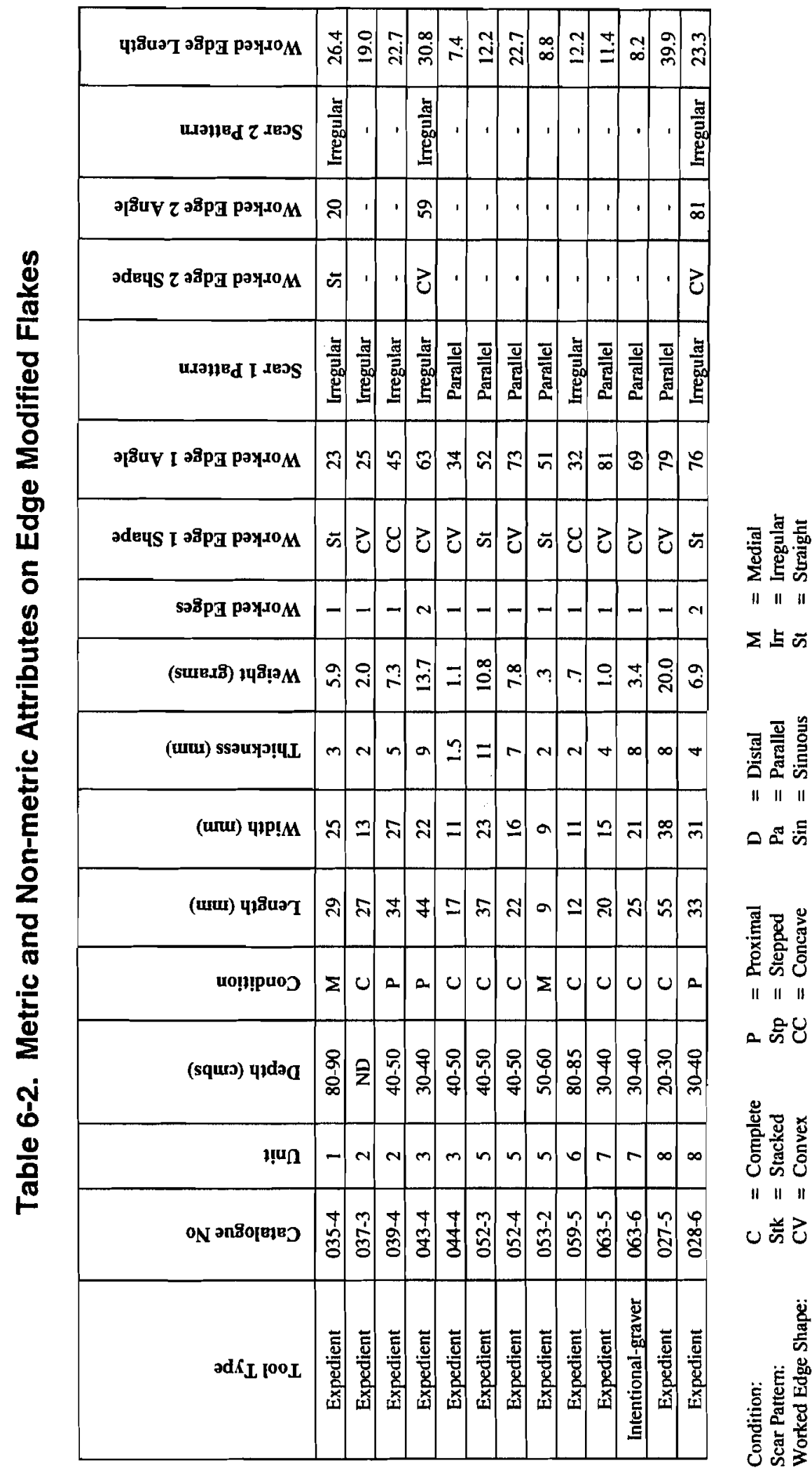




\section{Lithic Debitage ( $\mathbf{N}=750)$}

The assemblage of lithic debitage recovered from T1 terrace consists of a total of 750 items from seven test excavation units (Table 6-3 and 6-4). Three additional flakes were collected from BT 2 during TxDOT's test excavations, but these are not discussed here. The goal of the debitage analysis is to determine the range of technological indicators of chipped stone tool manufacture, maintenance, and discard activities conducted by the prehistoric inhabitants. Specifically, the analysis focuses on the relative degree of emphasis on bifacial versus unifacial lithic technologies and initial tool manufacture versus tool maintenance. Consequently, the typical debitage categories based on degree of cobble context (e.g., primary decortication flakes, secondary decortication flakes) were dispensed with in favor of categories that more directly reflect technological activities. The present classification scheme uses the following categories: core preparation flakes, early-stage biface flakes, late-stage biface flakes, tertiary thinning/retouch flakes, blades, tool rejuvenation flakes, angular debris, and indeterminate flakes. The definitions of each of these categories are presented here.

\section{Table 6-3. Debitage Types by Raw Materials}

\begin{tabular}{|c|c|c|c|c|c|c|}
\hline \multirow[b]{2}{*}{ Debitage Type } & \multicolumn{2}{|c|}{ Quartzite } & \multicolumn{2}{|c|}{ Chert } & \multicolumn{2}{|c|}{ Total } \\
\hline & Coarse & Fine & Coarse & Fine & No. & Percent \\
\hline Core Preparation Flakes & 11 & 35 & 38 & 42 & 126 & 16.8 \\
\hline Early-Stage Biface Flakes & 0 & 15 & 9 & 17 & 41 & 5.5 \\
\hline Late-Stage Biface Flakes & 0 & 25 & 36 & 94 & 155 & 20.6 \\
\hline Tertiary Thinning/Retouch Flakes & 1 & 26 & 21 & 56 & 104 & 13.8 \\
\hline Blades & 0 & 0 & 1 & 0 & 1 & 0.1 \\
\hline Tool Rejuvenation Flakes & 0 & 1 & 0 & 0 & 1 & 0.1 \\
\hline Angular Debris & 12 & 51 & 74 & 111 & 248 & 33.2 \\
\hline Indeterminate & 1 & 18 & 26 & 29 & 74 & 9.9 \\
\hline Total Count & 25 & 171 & 205 & 349 & 750 & \\
\hline Percentage & 3.3 & 22.8 & 27.3 & 46.6 & & 100.0 \\
\hline
\end{tabular}

Core Preparation Flakes - This category includes flakes, flake fragments, and pieces of angular debris associated with initial core preparation activities, such as removing test flakes to determine the quality of raw material within a cobble as well as decorticating a cobble for further reduction. Items in this category tend to have cortex covering more than 50 percent of their dorsal surfaces. By definition, most of these items tend to be relatively large (smaller flakes with dorsal cortex often fall within other categories, such as early- and late-stage biface flakes or indeterminate flakes, depending on their diagnostic characteristics). Core preparation flakes may or may not exhibit pronounced platforms, bulbs of percussion, or ventral concussion rings, though most do have one or more of these characteristics. 
Biface Manufacture Flakes-Biface manufacture flakes were classified based on the presence of multifaceted striking platforms, multidirectional dorsal flake scars, parallel to slightly expanding flake margins, and slight to moderate longitudinal curvatures. This category was subdivided into early- and late-stage biface manufacture flakes. Early-stage biface flakes tend to be somewhat larger than late-stage biface flakes, have fewer and larger dorsal flake scars, and may retain a considerable amount of cortex on their dorsal surfaces. As employed in this analysis, early-stage biface flakes correlate roughly with Callahan's (1996; cf. 1979) revised Stage 1, 2, and 3 bifaces ("blank," "rough out," and "primary preform" stages) while late-stage biface flakes correlate with Callahan's revised Stage 4 and 5 bifaces ("secondary preform" and "final preform" stages). In practice, Stage 1 ("blank") flakes are more likely to fall within the core preparation flake category due to the lack of clear diagnostic characteristics on many such specimens. Final percussion thinning, pressure thinning, and retouch flakes that do not clearly exhibit biface manufacture characteristics due to their small size would likely be included in the tertiary thinning/retouch flakes category. The early- and late-stage biface flake categories may contain complete flakes, proximal and distal flake fragments, and/or small pieces of angular debris that exhibit clear characteristics of the biface manufacture process (in practice, the latter type of debitage-angular debris bearing bifacial traits - is rare in the biface manufacture flake categories).

Tertiary Thinning/R etouch Flakes - This category includes flakes and proximal and dorsal flake fragments resulting from the final stages of tool manufacture, including final percussion thinning and any subsequent pressure retouch. By definition, flakes in this category tend to be quite small and it is difficult to distinguish whether they result from biface manufacture, uniface manufacture, or resharpening.

Blades - Loosely following Boyd et al. (1994:26), blades are long flakes that are at least twice as long as they are wide with single-faceted striking platforms (either corticate or decorticate), parallel unidirectional or opposed bidirectional dorsal flake scarring, dorsally trimmed platform preparation, and straight rather than curving longitudinal cross sections.

Tool Rejuvenation Flakes - Tool rejuvenation flakes are resharpening flakes removed through percussion or pressure flaking from the working bits of bifacial or unifacial tools in order to restore the working edge of the tool. Tool resharpening flakes bear use-related scarring indicative of tool use on the former bit edge. In addition to bit damage, tool rejuvenation flakes of sufficient size may also bear characteristics that reflect the overall morphology of the tool from which they were struck. 
Table 6-4. Distribution of Debitage in Test Units at 41JS102

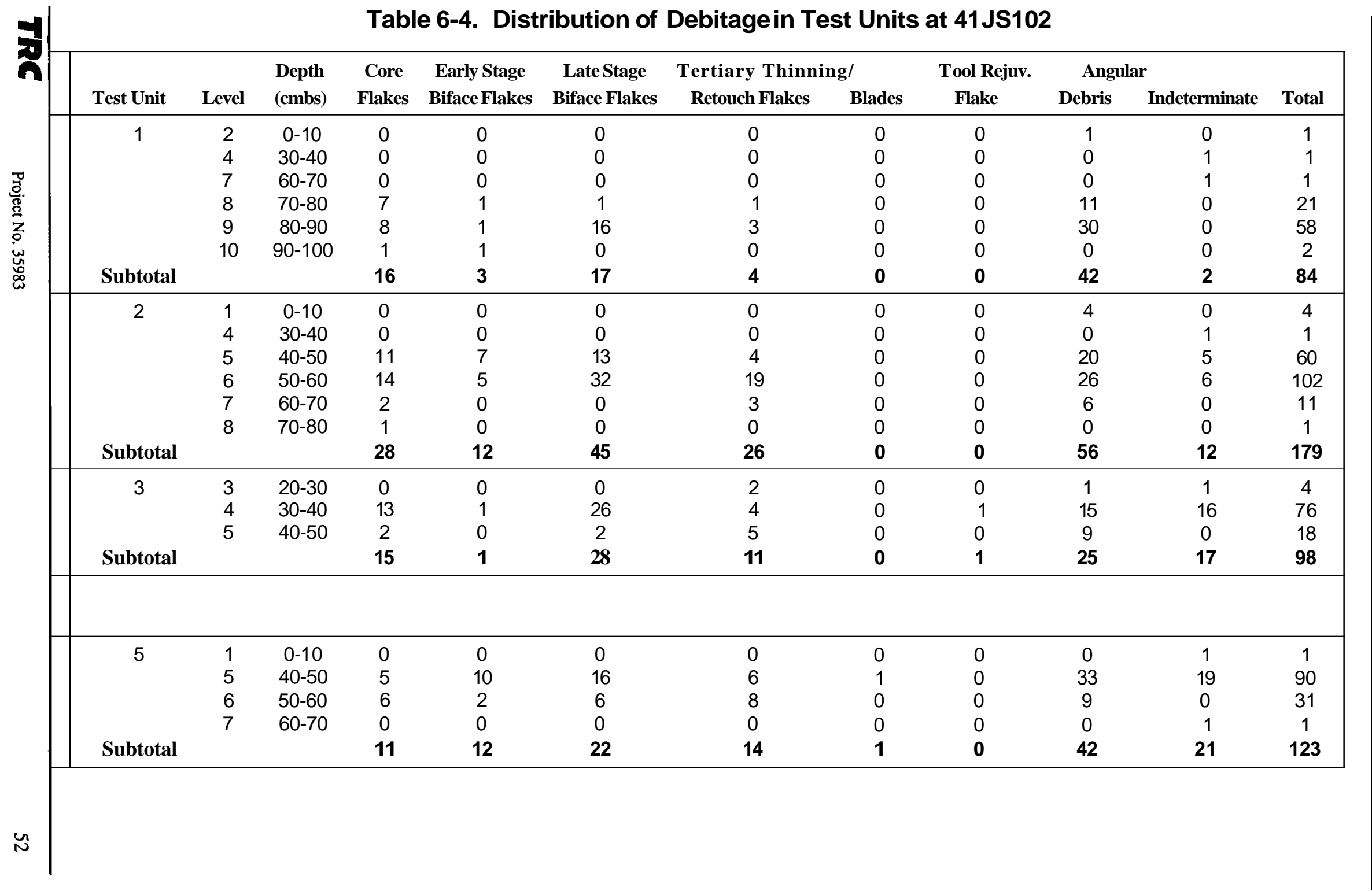


Table 6-4. (Continued)

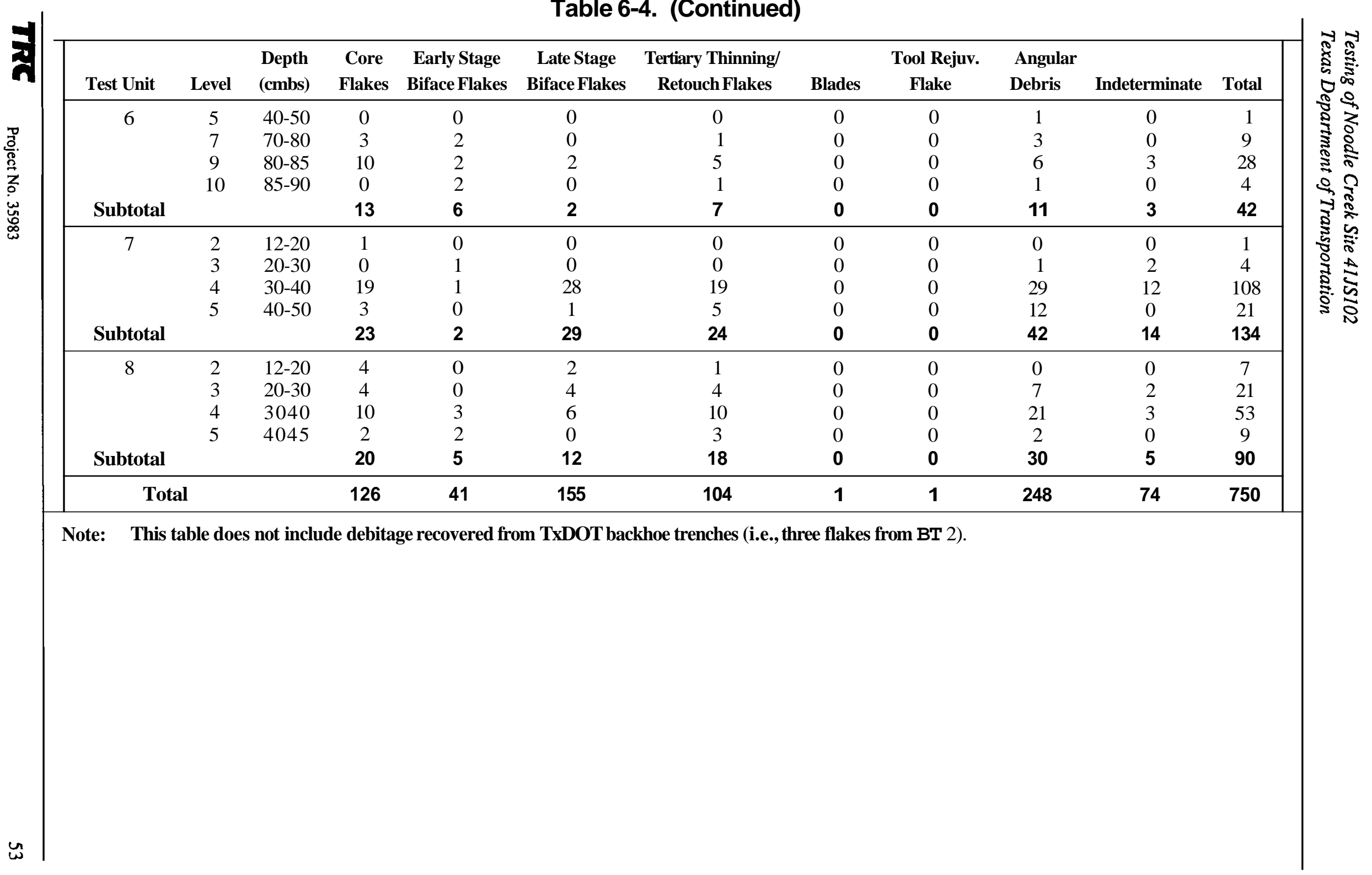


Angular Debris - Angular debris, or "shatter," includes angular pieces of lithic raw material that break away from the core as flakes are struck. In contrast to flakes, angular debris does not generally retain any diagnostic characteristics of the flintknapping process (i.e., platforms, bulbs of percussion, concussion rings, definable dorsal or ventral surfaces). In this analysis, those few pieces of angular debris that exhibit characteristics diagnostic of biface manufacture were included in the appropriate biface manufacturing category (i.e., early- versus late-stage biface flakes).

Indeterminate Flakes - This category includes flakes and flake fragments that lack diagnostic traits that would permit their placement into one of the other categories. Generally, these flakes are small fragments of flakes and/or thin pieces of angular debris that do not display clear evidence of a platform, concussion rings, or flake scar patterning on their dorsal surfaces. This category also includes a small number of potlid flakes and fractured heat spalls resulting from thermal alteration of raw materials.

Core preparation flakes are the second most common type of debitage in the assemblage ( $\mathrm{N}=126 ; 16.8$ percent). The overall quantity of core preparation flakes is roughly proportional to the number of biface manufacture flakes, which suggests that the prehistoric inhabitants of this site were procuring their raw materials locally and fashioning them into bifacial implements rather than importing decorticated tool blanks from elsewhere.

Biface flakes $(\mathrm{N}=196)$ represent slightly more than one quarter of the overall assemblage. Within the biface manufacture flakes, 20.9 percent are early-stage and 79.1 percent are late-stage flakes (the ratio of early-stage to late-stage biface flakes is 1:3.8). These figures suggest that the entire sequence of biface manufacture is represented. No overshot flakes were observed in the debitage assemblage. Overshot flakes are flakes struck at an overly acute angle that cause the flake to substantially "overshoot" the medial ridge of a biface, sometimes even removing part of the tool's edge opposite the edge from which the flake was struck.

Tertiary thinning/retouch flakes are ubiquitous in the debitage assemblage $(\mathrm{N}=$ 104; 13.8 percent) and clearly indicate that the final stages of tool production are represented at the site.

One blade was identified in the collection of debitage. This blade measures 3.4 $\mathrm{cm}$ in length, $1.1 \mathrm{~cm}$ in width, and $0.4 \mathrm{~cm}$ thick. The platform is single-faceted and exhibits extensive dorsal trimming, including multiple small step- and feather-fractures as well as one rather large hinge-fractured scar that extends approximately one-third of the way along the dorsal surface. This scar truncates the proximal portion of a straight, dorsal ridge that extends all the way to the distal end of the flake. This ridge represents 
the angle formed by two adjacent, longitudinal flake scars from previous blade removals that were struck from the same platform edge (concussion rings are visible on one facet and a partial bulb is evident on the other). The ventral surface of the flake exhibits a pronounced, longitudinal spiral twist. This item consists of a relatively coarse-grained, beige chert. The scarcity of blades indicates that these represent a very minor technological form.

Only one tool rejuvenation flake is present in the recovered debitage assemblage. This item is a small resharpening flake struck from a unifacial tool. The working edge has numerous small, use-related feather fractures along one edge of the bit. The opposing face of the bit does not exhibit any fracturing. This specimen consists of a waxy, somewhat lustrous, fine-grained, chocolate brown chert.

Angular debris accounts for a relatively sizable proportion of the assemblage $(\mathrm{N}=$ 248; 33.2 percent). The assemblage includes angular debris of all shapes and sizes, suggesting that all stages of the lithic production process are represented in this assemblage.

Indeterminate flakes account for a relatively small proportion of the debitage assemblage ( $\mathrm{N}=74 ; 9.9$ percent). Few conclusions can be advanced based on the small quantity of indeterminate flakes. It may be noted that fine-grained materials overshadow their coarse-grained counterparts within this category, suggesting that whatever technological activities might be reflected by this category, they broadly parallel the patterns observed in the other debitage categories.

Thermal Alteration - While the presence or absence of heat treatment was not systematically recorded, evidence of thermal alteration is present on approximately 15 to 25 percent of the specimens in the debitage assemblage. Evidence of thermal alteration includes pronounced pinkish and reddish hues of the matrix and/or mineral inclusions within the matrix, waxy texture, crazing, and "potlidding." In addition, several "potlid" flakes and heat-fractured spalls are present in the assemblage. Although these are not common, 10 to 20 (14 to 27 percent) of the specimens classified as indeterminate flakes are potlid and other heat-fractured spalls.

Technology Summary - Overall, the composition of the debitage assemblage indicates that the primary lithic technological activities undertaken at this site focused on biface manufacture. The preponderance of early and late stage biface production flakes, tertiary thinning, and pressure retouch flakes (many of which are presumed to be associated with biface trimming) clearly demonstrates that biface manufacture was a primary activity at this site. In fact, early- and late-stage biface manufacture represents 
the single largest specific category of technological activity identified at the site. Tertiary tool trimming and retouch flakes are also represented.

Unfortunately, the relative emphasis on tool manufacture versus maintenance activities cannot be identified based on the available evidence. Only one of the items in the debitage assemblage provides clear evidence of tool maintenance. This specimen is a tool rejuvenation flake from a unifacial implement. A sizable proportion of the debitage assemblage consists of flakes resulting from tertiary thinning and retouch $(\mathrm{N}=104 ; 13.8$ percent), but available evidence does not present any basis for distinguishing flakes resulting from tool resharpening versus those resulting from manufacture; most, if not all of the debitage is presumed to result from initial manufacture. Microscopic use-wear analyses of selected biface and tertiary trimming/retouch flakes might provide additional evidence relevant to this problem, but little more can be said about it at present.

It is rather difficult to estimate the degree to which the presence of final-stage biface thinning flakes represents the manufacture of bifacial preforms or the tools themselves. Only one projectile point, a Zephyr point, was recovered from testing. In contrast, four bifaces/bifacial preforms were recovered. Although it is likely that additional points are present in the unexcavated portions of the site, the scarcity of points relative to biface preforms may suggest that the prehistoric occupants of this site were manufacturing the preforms rather than the tools. Unfortunately, the assemblage is currently much too small to advance strong arguments one way or the other about this particular issue.

Unifacial tool technology is also represented at the site, as evidenced by 13 edgemodified tools recovered from test excavations (see above). In addition, one blade or bladelike flake was identified among the debitage, though no other indications of blade technology, such as pyramidal, unidirectional, or bidirectional blade cores or other blades, were recovered from the site. However, it should be noted that the dorsal surface of this blade exhibited flake scars resulting from the removal of two previous blades from a unidirectional blade core.

In the absence of a comparative collection of lithic raw materials from the project's vicinity, debitage was sorted into four broad raw material types-course- and fine-grained quartzites and course- and fine-grained cherts. In practice, these raw material categories form a continuum from very course quartzites with large, macroscopically observable crystalline structures to high-grade, cryptocrystalline cherts. However, it should be noted that almost all of the raw materials represented in the debitage assemblage are of relatively high quality. Even the "coarse-grained" cherts would probably be characterized as cryptocrystalline in a larger assemblage containing a 
more representative range of raw material quality. In addition, with a few exceptions, the fine-grained quartzites are metaquartzites that are easily equal in quality to most of the chert materials represented.

The composition of the assemblage of lithic debitage indicates a marked preference for high-grade material. Given that even the poorer examples of materials classified as fine-grained quartzites and coarse- and fine-grained cherts are of aboveaverage quality, virtually all $(\mathrm{N}=726 ; 96.7$ percent $)$ of the debitage would be characterized as deriving from cobbles of high-grade raw material. When present, the smooth, water-worn appearance of cortical surfaces on most of the flakes and cores in the assemblage indicates that raw materials were obtained in the form of cobbles, suggesting that most of the raw material nodules were probably collected from exposed gravel terraces or redeposited stream gravels.

The few items classified as "coarse-grained quartzites" generally consist of extremely large-grained quartzites. No biface manufacture flakes were identified that was made of course grained materials. In fact, aside from angular debris and an indeterminate flake, coarse-grained quartzites are represented almost exclusively in the form of core preparation flakes. These may represent testing flakes from cobbles that were not further reduced due to the ubiquity of high-grade materials in the area. The single coarse-grained quartzite, tertiary thinning/retouch flake was of a somewhat better grade than the remainder of the materials in this category.

The selection for high quality raw materials is also evident in the relatively higher proportions of biface manufacture flakes and tertiary thinning/retouch flakes manufactured from high quality materials. In fact, fine-grained materials outnumber coarse-grained materials within every debitage category. Combined with the evidence from the core assemblage, there appears to have been no shortage of high-quality raw materials available to the inhabitants of this site.

One final observation can be advanced about the component at site 41JS102 based on debitage analysis. As noted above, specific raw material varieties were not systematically identified due to the lack of a comparative collection of raw materials from the area. However, it was observed during the analysis of the debitage that very few distinct types of raw material appear to be represented in the assemblage - perhaps no more than one to two dozen distinct cobbles of material. In addition to the limited variety of raw materials present, a relatively small number of discrete knapping events appear to be represented by the debitage. For example, within each level, many of the biface production flakes appear to derive from a small number of bifaces (often no more than 
two or three), or at least from multiple bifaces manufactured from practically the same raw material.

Although this observation is obviously quite subjective, it suggests that the debitage present within this component was generated over a relatively short period of time or by multiple short-term occupations over a longer period of time. In either case, the depositional context of the soil deposits containing the lithic materials appears to be rather good. Even if cultural materials translocated up or down within the soil profile over a period of time, the composition of the debitage assemblage is very consistent, which strongly suggests that this component represents a rather short period of time and/or a rather focused occupation or series of occupations.

\section{Burned Rocks ( $\mathbf{N}=91)$}

The 90 burned rocks were relatively limited in number. About 70 percent were in the small size class between 0 and $4 \mathrm{~cm}$ in diameter. Another 24 percent were between 4.1 and $9.0 \mathrm{~cm}$, with only 6 percent between 9.1 and $15 \mathrm{~cm}$ (Table 6-5). These pieces were identified as limestone without obvious cracks. A number of pieces exhibited very distinctive hackled edges indicating they broke apart during rapid temperature change such as might occur with stone boiling activities. Only 10 pieces were scattered around the outside of Feature 1 in TU 8.

Table 6-5. Burned Rock Data from 41JS102

\begin{tabular}{|c|c|c|c|c|c|c|c|c|c|c|}
\hline \multirow[b]{2}{*}{ Unit } & \multirow{2}{*}{$\begin{array}{l}\text { Depth } \\
\text { (cmbs) }\end{array}$} & \multirow{2}{*}{\begin{tabular}{|c|} 
Feature \\
No. \\
\end{tabular}} & \multicolumn{3}{|c|}{ Size $(\mathrm{cm})$} & \multirow{2}{*}{$\begin{array}{c}\text { Material } \\
\text { Limestone }\end{array}$} & \multirow{2}{*}{$\begin{array}{l}\text { Shape } \\
\text { Round }\end{array}$} & \multirow[b]{2}{*}{ Cracks } & \multirow{2}{*}{$\begin{array}{l}\text { Total } \\
\text { Count }\end{array}$} & \multirow{2}{*}{$\begin{array}{c}\text { Total } \\
\text { Weight (g) }\end{array}$} \\
\hline & & & $0-4$ & 4.1 .9 & $9.1-15$ & & & & & \\
\hline 1 & $70-80$ & - & 16 & 3 & - & 19 & 19 & No & 19 & 306.0 \\
\hline 3 & $20-30$ & - & 1 & - & - & 1 & 1 & No & 1 & 7.4 \\
\hline 3 & $30-40$ & - & 13 & 6 & - & 19 & 19 & No & 19 & 480.0 \\
\hline 3 & $40-50$ & - & 6 & - & - & 6 & 6 & No & 6 & 51.6 \\
\hline 6 & $60-70$ & - & 2 & - & - & 2 & 2 & No & 2 & 5.4 \\
\hline 6 & $70-80$ & - & 11 & 3 & - & 14 & 14 & No & 14 & 192.2 \\
\hline 7 & $10-20$ & - & 2 & - & 2 & 4 & 4 & No & 4 & 571.4 \\
\hline 7 & $30-40$ & - & 6 & 3 & - & 9 & 9 & No & 9 & 166.5 \\
\hline 8 & $10-20$ & - & 1 & 2 & - & 3 & 3 & No & 3 & 279.1 \\
\hline 8 & $20-30$ & - & 3 & - & - & 3 & 3 & No & 3 & 75.4 \\
\hline 8 & $30-40$ & 1 & - & 3 & 3 & 6 & 6 & No & 6 & 398.9 \\
\hline 8 & $40-50$ & 1 & 2 & 2 & - & 4 & 4 & No & 4 & 167.4 \\
\hline BT 2 & Unknown & - & 1 & - & - & 1 & 1 & No & 1 & 24.0 \\
\hline Total & & & 64 & 22 & 5 & 91 & 91 & & 91 & 2725.3 \\
\hline \multicolumn{2}{|l|}{ Percent } & & 70.3 & 24.1 & 5.5 & 100 & 100 & & 100 & \\
\hline
\end{tabular}




\section{Mussel Shells $(\mathbf{N}=16)$}

Sixteen fragments of fresh water mussel shell, including parts of two unidentifiable hinges, were recovered from this component (Table 6-1). As these tiny pieces occur primarily in the same levels as most of the other cultural materials, it is assumed these shells were also culturally deposited. They lack any sign of cultural modification. It is not clear if they were used as a food resource or in some other capacity.

\section{Bones ( $\mathbf{N}=6)$}

Four tiny, unidentifiable bone fragments less than $3 \mathrm{~cm}$ long and weighing less about $4.6 \mathrm{~g}$ were within the top $30 \mathrm{cmbs}$ in TUs 5 and 6 (Table 6-1). The bone fragments contain cortical wall thicknesses that are similar to deer size bones, possibly representing ribs or long bone elements. Their surfaces are lightly weathered and have limited root etching, which supports their possible recent age. It is unclear what age these bone fragments represent, although their well-preserved condition and occurrence above the occupation zone might support an interpretation for recent age. Two other tiny bone fragments occurred in the same stratigraphic position as the occupation zone in TUs 1 and 8. These two fragments appear very similar to the other fragments, which may indicate they were displaced from more recent events.

\section{Historic Materials $(\mathbf{N}=\mathbf{1 1})$}

The historic scatter occurred from 2 to $3 \mathrm{cmbs}$ to about $20 \mathrm{cmbs}$ (Table 6-1). The collected historic assemblage from $\mathrm{T} 1$ units is limited to 11 recognizable items that include five clear glass fragments, including a neck fragment of a curved jar; four thin, rusted metal fragments, including many from a severely rusted can; one complete and apparently unused "U" shaped metal fence staple; and one rusted crown top bottle cap. No historic foundations or features were observed or encountered within the development zone. These 11 historic items were more or less vertically stratified above the majority of prehistoric materials with the exception of seven pieces of lithic debitage ( 0.9 percent of the assemblage), four burned rocks (4.5 percent), one edge modified flake (\#037-3; 5.0 percent), and four tiny, bone fragments, that were also from the same test units that contained the historic artifacts.

\subsubsection{Spatial Distribution on the T 1 Terrace}

At the extreme distal or northern end of the development zone, an east-west row of three units, TUs, 3,7, and 8, exposed a part of Feature 1, and from this one roughly 15 $\mathrm{cm}$ thick zone yielded 310 pieces of lithic debitage, 48 burned rocks, six mussel shell fragments, six edge modified flakes, three cores, and one Zephyr point, (Table 6-1). At the proximal or southern end of the T1 terrace, this same component yielded from TUs 1 
and 6,123 pieces of lithic debitage, 35 burned rocks, two mussel shell fragments, two edge modified flakes, two cores, and one biface. Somewhat centrally located between these two extreme ends, TUs 2 and 5 yielded 294 pieces of lithic debitage, five edge modified flakes, and one mussel shell fragment from this same component. Variations in the frequencies of the different material categories from these three areas hint at some possible differences in horizontal distribution that may represent different activity areas across this terrace surface. As an example, no burned rocks were recovered in the middle units whereas they were present in relatively high numbers from the proximal and distal terrace end. The middle two units, TUs 2 and 5 yielded no cores although these units yielded the highest frequencies of debitage. The limited number of units prevents clear indications of activity areas.

\subsection{Cultural Materials from the TO Terrace}

The lower $\mathrm{T} 0$ terrace immediately along the margin of the creek represents a very small area of the proposed development. Backhoe trenches 4 and 5 were dug on the sloping edge of the T1 and across part of the lower T0 terrace and TU 4 near the creek was dug entirely into the $\mathrm{T} 0$ deposits (Figure 4-1). No cultural occupation zone was recognized in these deposits, although scattered cultural materials were recovered. Backhoe trench 4 encountered a complete bison humerus (\#022-1) at $75 \mathrm{cmbs}$ with a tiny piece of charcoal about $5 \mathrm{~cm}$ away and another thick cortical, unidentifiable bone fragment in the trench wall. The humerus exhibited some weathering cracks and light acid etching, but no recognizable cultural modification. At approximately the same general depth a fragment of a second bone was detected in the trench wall. No prehistoric materials were discovered in trowelling the trench walls. Backhoe trench 5 was parallel and a few meters east of BT 4 , and did not encounter any prehistoric materials. The trench did expose a dark soil stain (10YR 3/2) with a chunk of charcoal and a tiny piece of burned earth estimated at about $95 \mathrm{cmbs}$ (Abbott n.d.). No cultural materials or rocks were associated with this stain.

Test Unit 4, placed $2 \mathrm{~m}$ south of BT 5, was excavated into the $\mathrm{T} 0$ deposits and yielded only one chert piece of angular debris, from 10 to $20 \mathrm{cmbs}$ of the $1.5-\mathrm{m}^{3}$ excavation (Table 6-1). At $150 \mathrm{~cm}$, the unit still had not encountered the same geologic strata that contained the cultural materials recovered from the other seven test units in the $\mathrm{T} 1$ deposits. The matrix at that depth was quite wet and difficult to screen. It was apparent that the same stratigraphic unit that contained the 10 to $15 \mathrm{~cm}$ thick cultural zone in the previous units in the $\mathrm{T} 1$ terrace was not represented in the lower $\mathrm{T} 0$ alluvial deposits. 
A few scattered historic items were between 10 and $70 \mathrm{cmbs}$ and include one clear glass bottle fragment, a lengthy section of barbed wire, two more unidentifiable bone fragments, and a severely rusted and fragmented tin can. The two, tiny bone fragments from 20 to $30 \mathrm{cmbs}$ are less than $3 \mathrm{~cm}$ long and weigh $2.3 \mathrm{~g}$. They are lightly weathered long bone fragments that have cortical wall thickness similar to deer size bones. At the base of $\mathrm{TU} \mathrm{4}$, between 130 and $140 \mathrm{cmbs}$ two more bone fragments weighing $1.0 \mathrm{~g}$ look similar to rib fragments from an artiodactyl such as deer or antelope. These lower fragments exhibit very minimal weathering and have a fresh surface appearance. A single unidentifiable fragment of a mussel shell was recovered from 10 to $20 \mathrm{cmbs}$. Based on a number of sediment characteristics and the recovery of the historic items, these TO deposits appeared to be by very recent alluvial clay and silt. 


\subsection{SUMMARY AND CONCLUSIONS}

In response to TxDOT plans to straighten the approach and replace the bridge on CR 347 where it crosses Noodle Creek, TRC staff completed the archeological assessment of site 41JS102 in December 2001 that was initiated by TxDOT archeologists in September 2001 following their site discovery investigations in June and July 2001.

Hand-excavations of $6.75 \mathrm{~m}^{3}$ from eight 1 by $1 \mathrm{~m}$ test units, coupled with the sixbackhoe trenches that removed $43 \mathrm{~m}^{3}$ of dirt were unequally distributed across the development zone on the north side of the Noodle Creek. All subsurface investigations with the exception of BT 6 were in the northeastern sector of the development. The documentation of BTs 1 through 5 revealed four major depositional packages in two alluvial terraces (TO and T1) of Noodle Creek (Figure 5). The lower T0 terrace is about 1 $\mathrm{m}$ above the creek whereas the higher $\mathrm{T} 1$ terrace is about $2.5 \mathrm{~m}$ above but gently slopes down toward the creek. The lower two depositional packages are more prominent in the $\mathrm{T} 1$ terrace whereas the higher and younger two packages are more pronounced in the TO terrace.

The basal unit (Unit I) identified consists of a red massive clay loam with about five percent, medium sized masses of carbonate. Unit I is interpreted as residual Permian shale that has probably weathered in place and represents a $4 \mathrm{C}$ horizon. No cultural materials were recovered from this unit.

The overlying unit (Unit 11) is also classified as a clay loam that exhibits two soil horizons (3ABk and 3Btk). The lower 3Btk horizon exhibits fine carbonate filaments, fine subangular blocky structure, tiny insect burrows, and rare sub-rounded alluvial pebbles up to $5 \mathrm{~mm}$ in diameter. The overlying $3 \mathrm{ABk}$ horizon is quite similar though it is slightly darker due to humate enrichment. Unit II is interpreted as overbank alluvium that is derived from reworking of clay rich Permian bedrock. The designation of an Ahorizon indicates a stable surface and cultural materials occur on the upper contact or within a few centimeters of Unit II. Based on the clay structure and the carbonates observed, Unit II was probably more resistant to erosion. It is concluded that the cultural materials resting on the surface of the 3Abk horizon are probably in situ and not deflated or reworked deposits.

A third unit (Unit III) consists of light brown, massive fine sandy loam-to-loam exhibiting characteristics of a $2 \mathrm{Bw}$ horizon. It exhibits a few fine carbonate filaments and is approaching a $\mathrm{Bw}$ horizon. Insect burrows, especially those of termites are present. Unit III covers nearly the entire investigated area. On the T1 terrace these sediments are typically 10 to $20 \mathrm{~cm}$ thick and occur at about 50 to $60 \mathrm{cmbs}$. On the To 
terrace Unit III is more than a meter thick and extend below the base of the trenches. A large bison humerus was about $5 \mathrm{~cm}$ into this horizon in the $\mathrm{T} 0$ terrace deposits. Within BT $1 \mathrm{a} 2 \mathrm{Ab}$ horizon was observed overlying the $2 \mathrm{Bw}$ horizon. This is a gray loam with very weak, fine granular structure, no visible carbonates, but it also had numerous insect burrows.

The forth unit (Unit IV) consists of multiple individual strata notable for their fine sandy loam structure and weak A horizon. On the T1 terrace, these sediments typically were 23 to $50 \mathrm{~cm}$ thick with three incipient A horizons. Due to the moisture in the sediments at the time of documentation it was impossible to clearly defined distinct boundaries between individual horizons.

Archeological excavations were also horizontally spaced across the northeastern development zone. The three most northerly sets of units, TUs 1 through 3 and 5 through 8 were dug into the T1 terrace. These seven hand-dug units encompassed $5.25 \mathrm{~m}^{3}$ and yielded a total of 871 pieces of cultural material concentrated in what appeared to be one 10 to $15 \mathrm{~cm}$ thick cultural component.

This component yielded one possible hearth like feature (Feature 1), one Late Archaic Zephyr dart point, three formal bifaces, a dozen informal or edge modified tools, five cores, lots of lithic debitage, and scattered burned rocks. A few scraps of fresh water mussel shells and lightly weathered bone fragments were also recovered, but their associations with the component is uncertain. If the bone and shell data sets are part of the cultural component, then they may indicate part of the food resources used by the occupants. Nearly 87 percent of the recovered material was lithic debitage. The high concentration of lithic debitage, the presence of five cores and three bifaces, and large decortification flakes, biface reduction flakes, indicates much of this component served as a knapping station or workshop for the production of bifaces. Numerous stone tools were undoubtedly processed as evident from the relatively high concentration of lithic debitage. Burned rocks account for about 10 percent of all materials and are assumed to have functioned in some cooking activity and were scattered about following their use. These burned rocks coupled with the charcoal concentration that may indicate a hearth (Feature 1), the presence of a projectile point, and potentially the bones and mussel shells may also imply that general camping activities were associated with the knapping area. Although the area investigated is limited in size, roughly $320 \mathrm{~m}^{2}$, the gross horizontal distribution of cultural data sets indicate an apparent horizontal separation of the two different activity areas.

The Zephyr point is relatively rarely reported form. Only a few specimens have been identified. Currently this point form is regionally restricted to about 18 counties in 
north central Texas (Prewitt 1995:138). Because of that limited distribution, this point type has not been discussed in any of the regional summaries of Central Texas (Prewitt 1981; Johnson and Goode 1994; Collins 1995). The Zephyr point may be related to the Mahomet points (Prewitt n.d., 1981) latter called Darl in Central Texas. Very little is known about the specific age of this type and associated cultural materials, and features. The Mahomet points in Central Texas occur within a ca. 300-year period between 1100 and 1400 B.P. (Prewitt 1985) and may indicate a general period of use. In more recent reviews of Central Texas, Johnson and Goode (1994) and Collins (1995) do not discuss either the Mahomet or Darl point types.

The presence of the Zephyr dart point indicates the presence of general Late Archaic temporal association, ca. 1400 to 2000 B.P. age, for the recovered materials in the 10 to $15 \mathrm{~cm}$ thick cultural component. However, the radiocarbon date obtained on a piece of wood charcoal from a questionable hearth, Feature 1, is not in agreement with the anticipated age of this Zephyr point. The $\delta^{13} \mathrm{C}$ corrected charcoal date of $400+/-40$ B.P. (Beta-162672) is much too recent for it to be correlated directly with the Zephyr dart point. Because the feature was very amorphous and contained rotting wood mixed with the charcoal, it may be that Feature 1 represents a burned tree that penetrated the cultural zone, and was not originally associated with the buried cultural component. This interpretation would account for the relatively late radiocarbon date in contrast to the assumed age of the Zephyr point of about 2000 B.P. Alternatively, if the charcoal date correctly dates the occupation zone, then the Zephyr dart point occurs in a the site as a scavenged collectable, In the latter case, the component dates to the very end of the Late Prehistoric period.

Test Unit 4, encompassing $1.5 \mathrm{~m}^{3}$, was dug into the lower $\mathrm{T} 0$ deposits and sampled primarily of Unit III and IV deposits. These alluvial deposits yielded only a single piece of chert debitage, a few bone scraps, but no recognizable prehistoric occupation zone. The recovery of recent historic artifacts to a depth of $70 \mathrm{cmbs}$ and the fresh appearance of a complete bison bone from $75 \mathrm{cmbs}$ in BT 4 indicates the sediments are probably quite recent to at least a depth of $150 \mathrm{cmbs}$. The oldest sediments, Unit I was not reached in TU 4. 


\subsection{RECOMMENDATIONS}

Based on the combined information obtained from 1) the geoarcheological understanding of the deposits, 2) the presence of quantities of cultural material, 3) the presence of formal and diverse stone tools, 4) the horizontal material diversity across the development zone, 5) the vertical isolation of the zone, and $\mathbf{6}$ ) the recovery of a point form that is not chronologically or culturally well documented, site 41JS102 appears to contain sufficient information potential to be eligible for inclusion in the NRHP and warrant designation as a SAL. It clearly has the potential to yield information important in prehistory as indicated by Criterion (d). The site appears to have good archeological context and integrity as the buried cultural zone is restricted to a relatively thin zone $(10$ to $15 \mathrm{~cm})$ in the T1 terrace deposits and appears to represent an in situ concentration as opposed to representing an erosional event. The cultural material may have been slightly, vertically dispersed over time by minor insect and/or soil movement processes. The association of the artifacts with a paleosol soil indicates that the materials could represent one or more use periods during a period of relative landform stability, or very slow sediment accumulation. Although the cultural material may not represent an occupation from a single point in time, the apparent integrity of this component would most likely represent a relatively narrow time frame. If this were true, the stratigraphic nature of the cultural zone combined with the relatively dense quantity of cultural material present would allow for significant contributions concerning other research issues. Those issues could include, but are not limited to chronology, technology, subsistence, site structure, and settlement organization, social organization, and behavior patterns.

The opening of a block excavation may yield other points. The layer sampled homogeneous or heterogeneous point types would solidify the identity of the groups that contributed materials to this occupation zone. The points that may come from a larger block excavation may also reflect the relative time when this component occurred, and provide a sufficient sample to study the variability within the type. The Zephyr type is not well understood at present, but the type has been known for the general region (Prewitt 1995). Isolated components containing this point type are not well documented and little is known concerning the assemblages associated with this possible cultural group.

In these alluvial deposits, charcoal and bone, from the cultural occupation may be preserved. If so, these remains could provide the necessary material for radiocarbon dating to more precisely define the age of this component. If these organic materials are not present, then residues from burned rocks may provide a potential dating medium. The burned rocks may also yield organic residues that would provide various chemicals 
to pursue studies of lipid residues and stable carbon and nitrogen isotope analyses. These chemical analyses may also be used to address general subsistence practices, if the bones and other indications of subsistence practices are not preserved.

The stone tools, lithic debitage, and burned rocks are all potentially useful for investigating various technological issues related to cooking, tool manufacture, resource procurement, hunting and collecting strategies. These same data sets may be horizontally clustered in separate areas and if so, their horizontal distribution may provide insights into the site structure and social organization. The linear nature of the roadway development zone, orientated perpendicular to the creek, may sample the range of cultural activities at the proximal, medial, and distal portions of the terrace and reflect how prehistoric activities were structured.

Paleoenvironmental data is also expected to be present, as the alluvial deposits appear to represent the last few thousand years and reflect potential changes in the regional environment. Despite some termite activities, the alluvial deposits do not currently appear to have experienced significant turbation. Therefore, the fine matrix may yield phytolith and stable isotope data to pursue reconstruction of past environmental conditions. If present, such faunal remains as mussel shells and bones may also contribute to an understanding of local environmental conditions.

Although the Principal Investigator recommended site 41JS102 as eligible for inclusion to the NRHP and as a SAL, the staff of the Archeological Studies Program in the ENV of TxDOT did not agree with that recommendation. Based on the information provided within the interim report (Scott et al. 2002) and repeated here in this document, they formulated a different opinion and forwarded that on to the THC for their review and comment (Appendix B). The staff at the THC concurred with the TxDOT recommendations that the site was not eligible for either the NRHP or as a SAL. The development was allowed to proceed without further archeological investigations. TxDOT also denied TRC's request for funds to conduct detailed analyses of any of the recovered charcoal, soil matrix, or burned rocks. 


\subsection{REFERENCES CITED}

Abbott, J. T.

n.d. Geoarcheological Content of Site 41JS102. Draft manuscript on file with Environmental Affairs Division, Texas Department of Transportation, Austin.

Barnes, V.

1974 Big Springs Sheet: Geologic Atlas of Texas, Scale 1:250,000. Bureau of Economic Geology, University of Texas at Austin.

Baumgardner, R. W. Jr.

1986 Stop 5: Terraces of the Upper Little Red River. In Geomorphology and Quaternary Stratigraphy of the Rolling Plains, Texas Panhandle, edited by T. C. Gustavson. Bureau of Economic Geology, Guidebook 22:20-28.

Birkeland, P. W.

1984 Soils and Geomorphology; Oxford University Press, New York.

Birkeland, P. W., M. N. Machette, and K. M. Haller

1991 Soils as a Tool for Applied Quaternary Geology. Utah Geological and Mineral Survey Miscellaneous Publication 91-3. Utah Department of Natural Resources, Salt Lake City.

Blair, W. F.

1950 The Biotic Provinces of Texas. Texas Journal of Science 2(1):93-117.

Bolton, H. E.

1949 Coronado: Knight of Pueblos and Plains. University of New Mexico Press, Albuquerque.

Boyd, D. K.

1995 The Palo Duro Complex: Redefining the Early Ceramic Period in the Caprock Canyonlands. Bulletin of the Texas Archeological Society 66:461-518.

1997 Caprock Canyonlands Archeology: A Synthesis of the Late Prehistory and History of Lake Allan Henry and the Texas Panhandle-Plains. Reports of Investigations, Number 110. Prewitt and Associates, Inc., Austin.

2001 Querechos and Teyas: Protohistoric Hunters and Gatherers in the Texas Panhandle-Plains, A.D. 1540-1700. Bulletin of the Texas Archeological society $72: 5-22$.

Boyd, D. K. and Tomka, S. A.

1997 Summary of Native American Archeology at Lake Alan Henry. In Caprock Canyonlands Archeology: A Synthesis of the Late Prehistory and History of 
Lake Alan Henry and the Texas Panhandle-Plains, D. K. Boyd, pp. 99-186. Reports of Investigations, Number 110. Prewitt and Associates, Inc., Austin.

Boyd, D. K., S. A. Tomka, M. D. Freeman, and J. Peck

1994 Research Organization, Objectives, and Methods. In Data Recovery at Lake Alan Henry (Justiceburg Reservoir), Garza and Kent Counties, Texas: Phase III, Season 3, by D. K. Boyd, J. Peck, S. A. Tomka, K. W. Kibler, and M. D. Freeman, pp. 9-28. Reports of Investigations, No. 93. Prewitt \& Associates, Inc., Austin.

Brown, T. M, K. L. Killen, H. Simmon, and V. A. Wulfkuhle

1982 Resource Protection Planning Process for Texas. Texas Historical Commission, Austin.

Callahan, E.

1979 The Preface From The Basics of Biface Knapping in the Eastern Fluted Point Tradition: A Manual for Flintknappers and Lithic Analysts. Third edition. Archeology of Eastern North America 7: 1- 180.

1996 The Basics of Biface Knapping in the Eastern Fluted Point Tradition: A Manual for Flintknappers and Lithic Analysts. Bulletin of Primitive Technology No. 11:56-60.

Castaneda, $\mathrm{P}$.

1904 The Journey of Coronado, 1540-1542. Translated and edited by George Parker Winship. Allerton Book Company, New York.

Collins, M. B.

1995 Forty Years of Archeology in Central Texas. Bulletin of the Texas Archeological Society 66:361-400.

Crook Jr., W. W.

1955 Reconnaissance and Geologic Revaluation of the Famous Abilene, Texas, Sites. Panhandle-Plains Historical Review 28:38-62.

Cruse, J. B.

1992 Archeological Investigations at the Kent Creek Site (41HL66): Evidence of Mogollon Influence on the Southern Plains. Publication No. 6. Panhandle Archeological Society, Amarillo.

Fenneman, N. M.

1938 Physiography of Eastern United States. McGraw-Hill Book Company, Inc., New York. 
Ferring, C. R.

1990 Archaeological Geology of the Southern Plains. In Archaeological Geology of North America, edited by N. P. Lasca and J. Donahue. Geological Society of America, Centennial Special Volume 4:253-266.

Flores, D.

1990 Caprock Canyonlands: Journeys into the Heart of the Southern Plains. University of Texas Press, Austin.

Forrester, R. E.

1951 A Series of Eighteen Indian Skeletons Excavated in Shackelford County, Texas. Bulletin of the Texas Archeological and Paleontological Society 22:132-143.

Freeman, M. D.

1990a Natural Resources Exploitation and Development: Buffalo Hunting on the Rolling Plains, 1874-1879. In Phase II Historical Investigations at Justiceburg Reservoir, Garza and Kent Counties, Texas, by M. D. Freeman and D. K. Boyd, pp. 7-48. Reports of Investigations No. 72. Prewitt and Associates, Inc., Austin.

1990b Agriculture in Texas: Ranching on the Western Rolling Plains, 1877-1945. In Phase II Historical Investigations at Justiceburg Reservoir, Garza and Kent Counties, Texas, by M. D. Freeman and D. K. Boyd, pp. 51-97. Reports of Investigations No. 72. Prewitt and Associates, Inc., Austin.

1999 A History of Fort Phantom Hill, The Post on the Clear Fork of the Brazos River, Jones County, Texas. Fort Phantom Hill Foundation.

Gile, L. H., F. F. Peterson, and R. B. Grossman

1966 Morphological and Genetic Sequences of Carbonate Accumulation in Desert Soils. Soil Science 106:6-15.

Guffee, E. J.

1989 Ballinger Reservoir: An Archeological Investigation on Valley Creek, Runnels County, Texas. Archeological Research Laboratory, Llano Estacado Museum, Plainview.

Hall, S. A.

1978 Late Holocene Alluvial Chronology from Northeastern Oklahoma. American Quaternary Association, fifth biennial meeting. Abstracts.

1982 Late Holocene Paleoecology of the Southern Plains. Quaternary Research 17:391-407. 
Hamrnond, G. P. and A. Rey

1940 Narratives of the Coronado Expedition, 1540-1542. University of New Mexico Press, Albuquerque.

Hays, J. S., R. L. Brooks, and J. L. Hofman

1989 Historical Archeology in the Southern Great Plains. In From Clovis to Comanchero: Archeological Overview of the Southern Great Plains, by J. L. Hofman et al. pp. 101-110. Arkansas Archeological Survey, Research Series No. 35.

Hodge, F. W. and T. N. Lewis (editors)

1984 Spanish Explorers in the Southern United States, 1528-1543. Texas State Historical Association, Austin.

Hofman, J. L.

1989 Prehistoric Culture History - Hunters and Gatherers in the Southern Great Plains. In From Clovis to Comanchero: Archeological Overview of the Southern Great Plains, by J. L. Hofman et al. pp. 25-70. Arkansas Archeological Survey, Research Series No. 35.

Hofman, J. L., R. L. Brooks, J. S. Hays, D. W. Owsley, R. L. Jantz, M. K. Marks, and M. H. Manhein

1989 From Clovis to Comanchero: Archeological Overview of the Southern Great Plains. Arkansas Archeological Survey, Research Series No. 35.

Holliday, V. T.

1997 Paleoindian Geoarchaeology of the Southern High Plains. University of Texas Press, Austin.

Hughes, J.T.

1978 Archeology of Palo Duro Canyon. Panhandle-Plains Historical Review 5 1:3553.

Johnson, E.

1987 Lubbock Lake: Late Quarternary Studies on the Southern High Plains. Texas A\&M University Press, College Station.

Johnson, L. and G. Goode

1994 A New Try at Dating and Characterizing Holocene Climates, as Well as Archeological Periods, on the Eastern Edwards Plateau. Bulletin of the Texas Archeological Society 65:1-51.

Kingston, M. (editor)

1991 1992-1993 Texas Almanac. Published for Dallas Morning News by A. H. Belo Corporation, Dallas; cited in D. K. Boyd, Caprock Canyonlands Archeology: A 
Synthesis of the Late Prehistory and History of Lake Alan Henry and the Texas Panhandle Plains. Reports of Investigations, Number 110, Volumes I and II. Prewitt and Associates, Inc., Austin.

Krieger, A. D.

1946 Cultural Complexes and Chronology in Northern Texas with Extension of Puebloan Dating to the Mississippi Valley. The University of Texas at Austin.

Krumbein, W. C., and Sloss, L. L.

1963 Stratigraphy and Sedimentation, 2nd ed. W. H. Freeman. San Francisco.

Kuchler, A. W.

1964 Potential Natural Vegetation of the Conterminous United States. American Geographical Society Special Publications, New York.

Lintz, C., A. C. Treece, F. M. Oglesby, K. Kibler, P. L. O'Neill, W. N. Trierweiler, C. Frederick, J. M. Quigg, and A. J. Taylor

1993 Cultural Resource Investigations in the O. H. Ivie Reservoir, Concho, Coleman, and Runnels Counties, Texas. Volume I: Project Introduction, Setting and Methods. Technical Report 346. Mariah Associates, Inc., Austin.

Kenmotsu, N.

2002 Letter to James E. Bruseth of the Texas Historical Commission.

Perttula, T. K.

1995 The Present and Future of Texas Prehistoric Archeology: An Introduction to the 1995 BTAS. Bulletin of the Texas Archeological Society 66:7-15.

Prewitt, E. R.

n.d. The Roger Springs Site: 1974 Investigations. Texas Archeological Survey Research Report 54 (manuscript), The University of Texas at Austin.

1981 Cultural Chronology in Central Texas. Bulletin of the Texas Archeological Society 52:65-89.

1982 Archeological Investigations at the Loeve-Fox, Loeve and Tombstone Bluff Sites in the Granger Lake District of Central Texas. Texas Archeological Survey, The University of Texas at Austin.

1985 From Circleville to Toyah: Comments on Central Texas Chronology. Bulletin of the Texas Archeological Society 54:201-238.

1995 Distribution of Typed Projectile Points in Texas. Bulletin of the Texas Archeological Society 66:83-173. 
Ray, C. N.

1928 A Differentiation of the Prehistoric Cultures of the Abilene Section. Bulletin of the Texas Archeological and Paleontological Society 1:7-22.

1935a The Pottery Complex Artifacts of the Abilene Region. Bulletin of the Texas Archeological and Paleontological Society 7:70-88.

1935b Some Unusual Cremated Burials. Bulletin of the Texas Archeological and Paleontological Society 7:130-131.

1937 More Evidence Concerning Abilene Man. Bulletin of the Texas Archeological and Paleontological Society 9:193-217.

1938 The Clear Fork Culture Complex. Bulletin of the Texas Archeological and Paleontological Society 10:193-207.

1939 Some Unusual Abilene Region Burials. Bulletin of the Texas Archeological and Paleontological Society 1 1:226-250.

1940 The Deeply Buried Gibson Site. Bulletin of the Texas Archeological and Paleontological Society 12:223-237.

Ray, C. N. and E. B. Sayles

1941 An Agreement on Abilene Regional Terminology. Bulletin of the Texas Archeological and Paleontological Society 113:175-176.

Reineck, H. E., and Singh, I. B.

1980 Depositional Sedimentary Environments, 2nd ed., Springer-Verlag, Berlin.

Roe, F. G.

1972 The North American Buffalo: A Critical Study of the Species in its Wild State. 2nd edition, David and Charles, Newton Abbott, England.

Rogers, C. A., A. R. Goerdel, and H. D. Gooch

1972 Soil Survey of Jones County, Texas. United States Department of Agriculture, Soil Conservation Service, in cooperation with the Texas Agricultural Experimental Station.

Saunders, J. W., C. S. Mueller-Wille, and D. L. Carlson

1992 An Archeologial Survey of The Proposed South Bend Reservoir Area: Young, Stephens, and Throckmorton Counties, Texas. Archeological Surveys No. 6, Archeological Research Laboratory, Texas A\&M University.

Sayles, E. B.

1931 Some Flint Sources in Central West Texas. Bulletin of the Texas Archeological and Paleontological Society 3:18-23. 
1935 An Archaeological Survey of Texas. Medallion Papers 17. Gila Pueblo, Globe Arizona.

Scott, A. L., G. D. Smith, and J. M. Quigg

2002 Testing of Noodle Creek Site 41JS102 Jones county, Texas: An Interim Report. TRC Environmental, Inc. TRC Project 34136, Austin.

Soil Survey Staff

1962 Soil Survey Manual. Agricultural Handbook No. 18. Washington, D.C., U.S. Department of Agriculture.

1975 Soil Taxonomy. Agricultural Handbook No. 436. Washington, D.C., U.S. Department of Agriculture.

Suhm, D. A., A. D. Krieger, and E. B. Jelks

1954 An Introductory Handbook of Texas Archeology. Bulletin of the Texas Archeological Society, Vol. 25.

Thurmond, J. P., M. D. Freeman, and S. L. Andrews

1981 A Preliminary Assessment of the Cultural Resources in the Brazos Natural Salt Pollution Control Project, Kent, King, and Stonewall Counties, Texas. Reports of Investigations, Number 18, Prewitt and Associates, Inc., Austin.

Tunnell, C.

1975 Fluted Projectile Point Production as Revealed by Lithic Specimens from the Adair-Steadman site in Northwest Texas. Texas Historical Commission, Office of the State Archeologist Special Report 18, Austin.

2000 In Their Own Words: Stories from Some Pioneer Texas Archeologists. Bulletin of the Texas Archeological Society 7 1:1-146.

Waters, M. R.

1992 Principles of Geoarchaeology: A North American Perspective. University of Arizona Press, Tucson.

Weir, F. A.

1976 The Central Texas Archaic. Unpublished Ph.D. dissertation, Department of Anthropology, Washington State University, Pullman.

Wheat, J. B.

1940 Preliminary Report on the Excavations of the Hodge Site. Bulletin of the Texas Archeological and Paleontological Society 12:195-216. 
Willey, P. S. and J. T. Hughes

1978 The Deadman's Shelter Site. In Archeology at MacKenzie Reservoir, edited by J. T. Hughes and P. S. Willey, pp. 149-190. Office of the State Archeologist, Survey Report No. 24. Texas Historical Commission, Austin.

Worminton, H. M.

1957 Ancient Man in North America. The Denver Museum of Natural History, Popular Series No. 4.

Wulfkuhle, V. A.

1986 Investigations into the Prehistory of the Upper Clear Fork of the Brazos River, Fisher and Jones Counties, Texas. Unpublished Master of Arts thesis, The University of Texas at Austin.

Internet Addresses

2002 http://www.fortphantom.org, May 22. 


\subsection{GLOSSARY OF TECHNICAL TERMS}

A Horizon: The near surface horizon of a natural soil profile. This is a carbon rich often melanized or darkened soil horizon characterized by an accumulation of partially decomposed to decomposed organic matter and eluvial loss of constituents such as clays and carbonates, which tend to accumulate in the deeper B horizon. The A horizon represents the upper solum of a soil. Lower case letters with the upper case A indicate specific characteristics of that A horizon. An Ab designation indicates the A horizon is buried. An Ap designation indicates a disturbed or anthropically modified soil such as in a plow zone.

Accelerated Mass Spectrometry (AMS): Laboratory technique that separates and identifies ions based on their mass to charge ratios. This technique is used in radiocarbon dating tiny particles of carbon in organic remains and residues.

Allostratigraphic Unit: Depositional unit made up of sediments dating to a coeval period of deposition.

Alluvium: Clastic sediments deposited by a flowing stream, either in the channel or material deposited outside the channel during overbank flooding.

Argillic Horizon: A soil horizon (Bt horizon) that exhibits significant enrichment in illuvial clay minerals or clay-sized particles. Such clays typically form grain coats, grain bridges, and ped-face coats of oriented clay that are visible in thin secions, and usually can be identified with a hand lens.

Artiodactyl: Any various hoofed mammal with an even number of toes on each foot such as buffalo, cow, deer, or antelope.

B Horizon: The lower solum of a natural soil. A B horizon is a mineral soil horizon characterized by an accumulation of constituents such as clays, carbonates or salts, or organic complexes that have been translocated from the A horizon. Common subordinates include lowercase letters such as $\mathrm{t}$, which indicates accumulation of illuvial clays. The lowercase $\mathrm{k}$ indicates accumulation of carbonate. The lower case $\mathrm{w}$ indicates structural or color changes with no significant accumulations of alluvial material.

Bioturbation: The churning and mixing of sediments by living organisms, including burrowing rodents, insects, worms, and plant roots.

B.P.: An abbreviation for before present, which in radiocarbon dating is referenced to the standard year A.D. 1950. 
C Horizon: Weathered, but relatively minimally altered parent material at the base of a soil profile. Roughly synonymous with subsoil, although the latter term is often used to encompass the lower B horizon.

Calcareous: Rocks, minerals, or sediment containing calcium carbonates. A calcareous soil contains enough calcium carbonated to effervesce visibly when treated with dilute hydrochloric acid.

Cenozoic: The lastest era of geologic time, which includes the Tertiary and Quaternary periods.

Clast: Any detrital particle (sediment) created by the weathering and disintegration of a larger rock mass and transported by, or subjected to physical transport by water, wind, or ice. Clast also includes discrete particulates created and deposited by volcanic action.

Clay cutans: Thin skins of clay that cover other particles.

Clay loam: A soil that contains 27 to 40 percent clay and 20 to 45 percent sand.

Colluvium: Soil material that has been moved downslope and is deposited on a slope by gravity.

Context: The association and position of artifacts, materials, and cultural features that are used by archeologists to interpret space, time, and cultural associations.

Cumulic Soil: A soil formed in a setting experiencing relatively slow deposition, so that freshly introduced sediment is incorporated into the A horizon, leading to overthickening of the surface horizon. Cumulic soils are common in alluvial overbank and colluvial settings.

Eolian: Refers to sedimentary process and deposits resulting from the action of wind, often in the form of sand accumulations.

Erosional Uncomformity: A significant break or gap in the depositional record, indicative of erosion of the older unit prior to renewed deposition.

Fossiliferous: The matrix of the rock contains fossil plant or animal remains.

Holocene: Geological time period spanning roughly the last 10,000 years before present. The Holocene is roughly equivalent to the Post-glacial period, and often referred to as the "Recent" period in geology. Many investigations consider the Holocene to be an interstadial in the ongoing Pleistoceneepoch.

Horizon: A discrete, relatively uniform layer in a soil profile that is typically subparallel with the surface and formed as the result of pedogenic process. 
Humic: A dark, organic-rich material generally caused by the decay of organic material.

Knapping: A term used to describe the making of prehistoric chipped stone tools using different techniques, such as pressure and or percussion methods, to chip/flake a lump of stone material to form a useful tool.

Krotovina: A discrete, anomalous area visible in plan or profile in a soil resulting from the infilling of a void (e.g. a burrow or root) with dissimilar sediment. Some investigators prefer to limit the term to animal burrows, preferring the term "root trace" for filling related to decayed roots. Some krotovina are obvious, whereas others are tiny and may only be identified in thin sections.

Loam: Is a soil that contains 7 to 27 percent clay, 28 to 50 percent silt, and less than 52 percent sand.

Matrix: In geoarcheological usage, refers to the sediments in which the artifacts at an archeological site are encased.

Overbank Deposits: The deposition of fine silts and clay particles that are left on terrace tops and banks when water in creeks exceeds the capacity of the channel and drops the suspended sediments load in the lower energy environment. Overbank depositional processes usually cause minimal movement to large objects on the terrace top.

Palimpsest: Archeologically, refers the inability to distinguish and separate materials from repeated occupations by a succession of people of different ages due to the deposition of artifacts over time on relatively stable surface. Some palimpsest assemblages are buried following a long period of accumulation.

Pedogenesis: The dynamic process of soil formation and development, which typically leads to the formation of a darkened, organic-rich A-horizon at or near the surface, and the downward movement of fine clays and/or the formation of carbonate nodules in lower B horizons.

Permian: The last period of time in the Paleozoic Era spanning the time from about 270 to 225 million years ago. This is divided into four epochs.

Pleistocene: The first epoch, which along with the Holocene period constitutes the Quaternary period. The Pleistocene spans the time between roughly 2.0 or 1.65 million years ago and 10,000 years ago. Characterized by repeated continental glaciations, the Pleistocene witnessed the evolution of modern humans, and extinctions of megafauna. 
Potlid: A circular or oval piece of lithic debitage with a flat dorsal and a convex ventral surface that lacks a platform or other attributes of a flake. It is caused by rapid expansion of siliceous material during exposure to excessive heat. The parent flake of stone will have a small to moderate size pitted or dish-shaped scar. Potlids generally reflect thermal damaged chert that were not intentionally produced during heat treatment.

Profile: A sequence of horizons that make up a soil, or a description or depiction of the horizons in cross section.

Provenience: The specific vertical and horizontal location where an object is found.

Quaternary: The second period, which along with the Tertrary Period make up the Cenozoic Era, encompassing the Pleistocene and Holocene epochs; roughly spanning the last 2.0 to 1.65 million years.

Sandy loam: A soil that contains 30 percent or more of coarse to medium sand but less the 25 percent very coarse sand and less than 30 percent very fine sand.

Silt: A particle size that has a range from $0.06 \mathrm{~mm}$ to $0.002 \mathrm{~mm}$.

Siliceous: A silicon dioxide, the most common chemical constituent on earth, a dominant component of chert and quartz.

Site Structure: The spatial distribution of features, artifacts, and debris across a single occupation (component) of an archeological site that is used to reconstruct manufacture, maintenance, processing, production, and disposal activity areas at specific loci, and the spatial ways prehistoric groups organized their space at a site.

Tertiary: The first period of the Cenozoic era, extending from the Cretaceous period of the Mesozoic era to the Quaternary period of the Cenozoic era.

Turbation: Disturbance to the natural matrix deposits generally caused by biological (burrowing rodents, insects, worms, and plant roots) and natural (soil creep, desiccation crack displacement, frost heaving, landslides, etc.) processes. 


\section{APPENDIX A}

Radiocarbon Results 


\section{. 逐田 \\ Moth Aninume the.

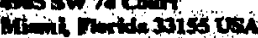 \\ ats 3015 \\ 7ux pes cos

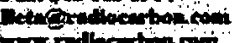

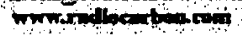

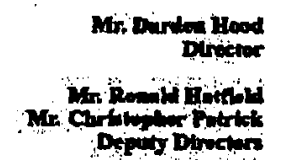

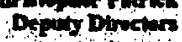

Dr.J amesAbbott

Report Date: 1/8/02

T exas D epartment of T ransportation

M aterialReceived: 12/13/01

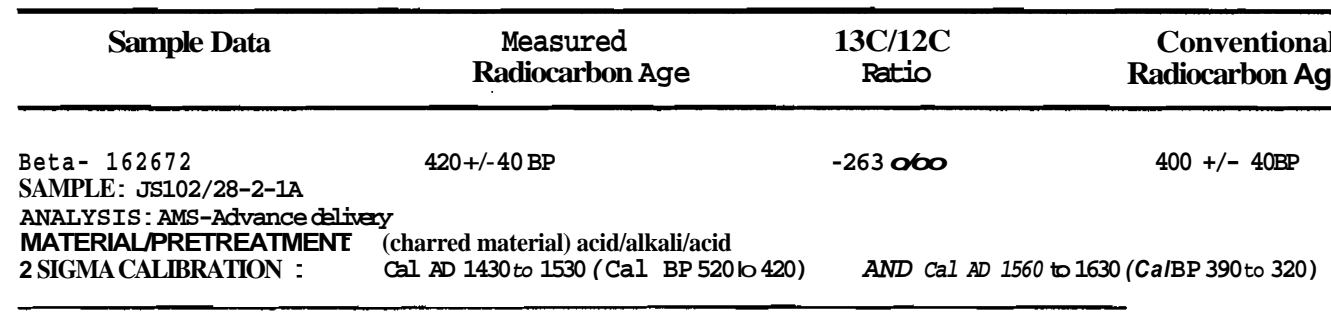




\section{CALIBRATION OF RADIOCARBON AGE TO CALENDAR YEARS}

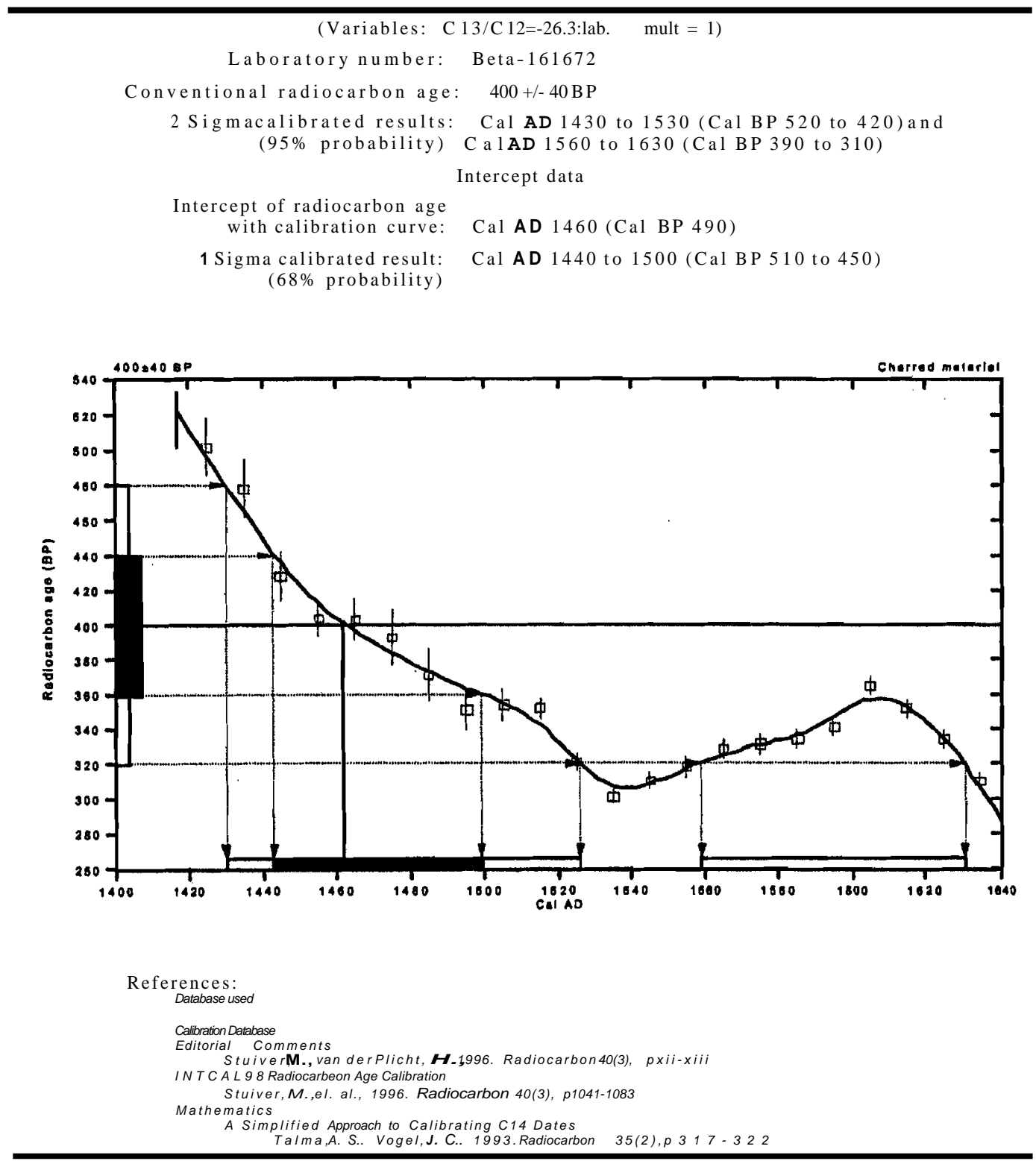

Beta Analytic Inc.

4985 SW 74 Court, Miami, Florida 33155 USA.Tel:(305)6675167 - Fax: (305)663 0964.E-Mail: beta@ radiocarbon.com 


\section{APPENDIX B}

Texas Department of Transportation Letter to the Texas Historical Commission 


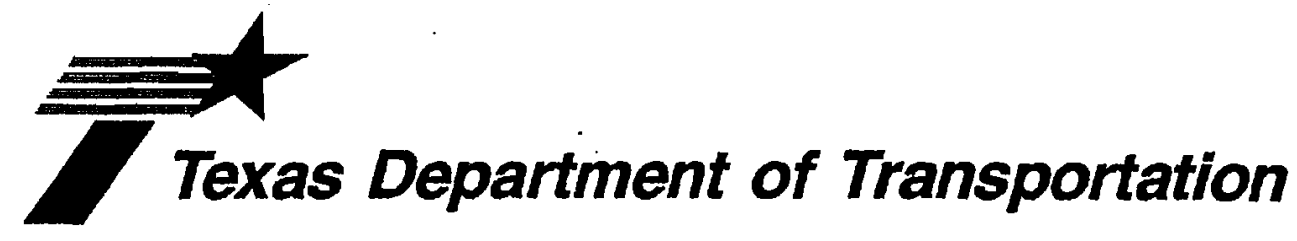

DEWIT C. GREER STATE HIGHWAY BLDG, • 125 E. 117H STREET • AUSTN, TEXAS $78701 \cdot 2483$ • (512) 4638585

February 1,2002

RE: RecommendationsConcerning National RegisterEligibility of Site 41JS102

County Road Bridge Replacement, Jones County, CSJ: 0908-24-033

James E. Bruseth, Ph.D.

Department of Antiquities Protection, Texas Historical Commission

P.O. Box 12276

Austin. Texas 78711

Dear Dr. Bruseth:

In accordance with the Programmatic A greement(PA) among TxDOT, Federal Highways A dministration, the Advisory Council on Historic Preservation, and the Texas Historical Commission (THC) and the Memorandum of Understanding among TxDOT and the THC, the lettercontinues our consultation for the above-referenced project.

A prehistoric site designated 41JS102 was identified in 2001 during an archeological survey of a county road bridge at CR 347 and Noodle Creek in JonesCounty. On December 18, 2001, TRC Environmental obtainedTAC permit 2747 to test the locale on behalf of TxDOT to determine the potential eligibility of the archeological deposits for National Register of Historic Places (NRHP).

Subsequently, TRC Environmental's excavations included eight 1x1 meter units and five backhoe trenches (see attached report). Based on the recovered material, TRC recommended that the portion of the site within the proposed right-of-way (RWO) meets evaluation Criterion D of $\mathrm{N}$ ational Register eligibility. TRC Environmental proposed that the site may belikely to yield information important in prehistory for the following reasons:

1.) Geoarcheologicalinterpretation: A rcheological materials were deposited by peoples occupying the $3 \mathrm{~A} B \mathrm{~K}$ horizon and not by erosion. The justification for this interpretationis the presence of carbonates developing in the ensuing overburdenafter the cultural materials were deposited and covered.

2.) The quantity of cultural material:A total of 826 pieces of cultural debris were recovered from the test excavation.

3.) The presence of formal and diverse tools: collected material (826 fragments mostly of lithic debris) consisted of707 (85\%) pieces of debitage; 104 (13\%) fragments of burned rock and eight bone and seven shell fragments. One small reworked projectile point was recovered and identified as a L ate A rchaic Zephyr dart point. Two additional chronologically undiagnostic subovate bifaces were also recovered.

4.) The horizontal distribution of materials across the proposed ROW: (Feature 1 (the only feature discovered), a possible hearth located on the northern portion of the area of investigation, exhibited relatively less dense debitage than the rest of the area suggesting activity areas.

5.) The vertical distribution of deposits across the proposed ROW : M ost of the artifacts were obtained from a distinct thin, yet moderately dense band of cultural deposits approximately 10 - 
$15 \mathrm{~cm}$ thick. The deposit was buried below a relatively sterile overburden varying in thickness from $30 \mathrm{~cm}$ at the northern end to $85 \mathrm{~cm}$ in the Southern portion.

Based upon a considered review of the findings of TRC Environmental's testing report, we cannot concur with their recommendation that the portion of 41JS102 within the proposed ROW meets the criteria for inclusion in the NRHP. It is our opinion that subsurface testing has demonstrated that: (1) the archeological deposits within the ROW have been disturbed (due to overprinting), (2) are chronologically problematic due to the lack of radiometric data, and (3) the paucity of chronologically diagnostic lithic tools and the lack of associated assemblage(s) would compromise any successful effort todiscern cultural traits in further studies.

Our conclusion is based upon the following responses to the items identified by TRC Environmental:

1.) Geoarcheological interpretation: TRCEnvironmental's analysis doesnot adequately address the contrasting possibility that the cultural materials residing on the $\mathbf{3 A B K}$ horizon were deposited over a long period of stability and thus represents overprinting by multiple cultural entities.

2,) The quantity of cultural materials: Although 826 fragmentsof cultural debris were recovered from theexcavation, the quantity of artifacts does not in itself justify the site's eligibility for NRHP inclusion. Rather, the potential contribution of the artifact assemblage(s) in interpreting the prehistoric development of the region should be the threshold for the criterion that determines eligibility. We do not believe it can be convincingly demonstrated that the lithic debris is derived from one or many chronological periods. In TxDOT's opinion, TRC Environmental has not demonstrated how or why the quantity of artifacts consisting of lithic debris with little or no chronological or cultural association can meaningfully contribute to the current understanding of the region's prehistoric development. In addition, in regard to the potential information obtained through residue analysis of burned limestone, it is our understanding from TRC Environmental that this form of analysis has historicallydemonstrated very limited research value.

3.) The presence of formal and diverse tools: As noted, of the 826 recovered artifacts, $707(85 \%)$ were debitage, and 104 (13\%) were of burned rock. Eight fragmentsof bone and seven of shell were also collected. One projectile point was recovered from one feature and classified as a Zephyr dart point as well as two other bifaces. In TxDOT's opinion. the collectiondoes not constitute a diversity of tool types. Only one projectile point, apparently a reworked Zephyr has a general chronological association. Based upon the paucity of recovered tools in relation to excavated soil (hand and mechanical exposed $47 \mathrm{~m}^{3}$ ), we believe the remaining site in the ROW possesses very limited potential to yield additional formal diagnostic tools.

4.) The horizontal distribution across the proposed ROW: Feature 1, a possible hearth located on the northern portion of the area of investigation, exhibited relatively less dense debitage than the rest of the area suggesting activity areas. TRC Environmentaldiscounted the site's sole radiocarbon assay $(400 \mathrm{BP}+\mathrm{H}-40)$ that was associated with the feature because it did not fit the time frame of the Late A rchaic Zephyr dart point recovered nearby. TRC Environmental suggests that the carbon came from the intrusive root of a bumed tree. Discounting this sole date renders the feature nearly meaningless in regard to contributing to site interpretation and intrasite spatial analysis. It also means that, at present, there is no expectation of features at the site to contribute to meaningful analysis and interpretationfrom mitigation efforts. In contrast, if the date is valid it may represent an intrusive feature indicating depositional overprinting by multiple unidentifiable episodes of use.

5.) The vertical distribution across the proposed ROW. The vast majority of the lithic debris is contained in a distinct thin band of cultural deposits approximately $10-15 \mathrm{~cm}$ thick buried below 
a relatively sterile overburden. TxDOT feels that it is al so plausible to interpret this as the deposition of cultural materials on a stable ground surface over a very long period of time and therefore representing artifact mixing and overprinting by two or morecultural entities. In TXDOT'S opinion, the deposit in the project area does not contain the data potential to reject this interpretation. The lack of associated radiocarbon assays in both vertical and horizontal distributions precludes any clear resolution of this issue.

For these reasons, TXDOT recommends that the portion of 41JS102 residing in the proposed ROW and investigated by TRC Environmental does not contain an archeological deposit that is eligible for listing on the NRHP or for designation as a State Archeological L andmark. TxDOT seeks SHPO concurrence for the following recommendations for that portion of site 41J S102 within the county road ROW:

1.) The portion of 41JS102 residing in the proposed bridge and approachesdevelopment is not eligiblefor listing on the NRHP or for designationas a SALand does not warrant further work

2.) No historic properties listed or eligible for listing on the NRHP or for designation as a State A rcheological Landmark will be impacted by the proposed bridge or approaches development

3.) The proposed bridge and approachesreplacement may proceed to construction.

Thank you for your consideration in this matter. If you have any questions or require further information. please contact Jon Budd at (512) 416-2640.

\section{Hinulu L. Ximunotus}

Nancy Kenmotsu, Ph.D., Supervisor

ArcheologicalStudies Program

Environmental Affairs Division

Attachments

cc w/ attachments: TRC Environmental: Attn: Mike Quigg,

bcc w/o attachments: Jon Budd - TXDOT ENV

bcc w/attachments: SBW-TxDOT ENV , Bil L each - A bilene District, J ulie Perales - TxDOT ENV

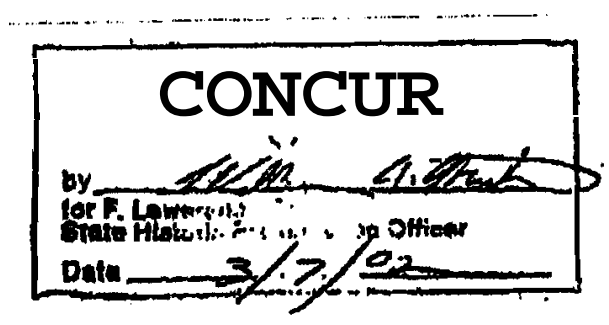

